UNIVERSIDADE DE SÃO PAULO

FACULDADE DE FILOSOFIA, LETRAS E CIÊNCIAS HUMANAS

DEPARTAMENTO DE LETRAS CLÁSSICAS E VERNÁCULAS

PROGRAMA DE PÓS-GRADUAÇÃO EM FILOLOGIA E LÍNGUA PORTUGUESA

SANDRA REGINA MARCELINO PINTO

\title{
NA RODA DE SAMBA EU SOU BACHAREL: ANÁLISE DE 21 CANÇÕES DE NOEL ROSA
}




\title{
NA RODA DE SAMBA EU SOU BACHAREL: ANÁLISE DE 21 CANÇÕES DE NOEL ROSA
}

\author{
Versão corrigida
}

Dissertação apresentada ao Programa de Pós-graduação em Filologia e Língua Portuguesa do Departamento de Letras Clássicas e Vernáculas da Faculdade de Filosofia, Letras e Ciências Humanas da Universidade de São Paulo, para a obtenção do título de mestre em Letras.

Orientador:

Prof. Dr. Osvaldo Humberto Leonardi Ceschin

SÃo PAULO

2011 
Autorizo a reprodução e divulgação total ou parcial deste trabalho, por qualquer meio convencional ou eletrônico, para fins de estudo e pesquisa, desde que citada a fonte.

Pinto, Sandra Regina Marcelino

$\mathrm{Na}$ roda de samba eu sou bacharel: análise de 21 canções de Noel Rosa / Sandra Regina Marcelino Pinto ; orientador Osvaldo Humberto Leonardi Ceschin. - São Paulo, 2011.

$137 \mathrm{f}$.

Dissertação (Mestrado) - Faculdade de Filosofia, Letras e Ciências Humanas da Universidade de São Paulo. Departamento de Letras Clássicas e Vernáculas. Área de concentração: Filologia e Língua Portuguesa.

1. Música popular - interpretação. 2. Música popular Brasil. 3. Rosa, Noel, 1910-1937. I. Título. II. Ceschin, Osvaldo Leonardi Humberto. 
Aos meus pais:Sebastião e Dora grande orgulho da minha vida. 


\section{Agradecimentos}

À Maria das Dores Marcelino Pinto (Dora) e Sebastião Pinto: meus pais. Ela me contava histórias na infância, sem me deixar tocar nos livros (para não danificá-los) responsável pelo meu desejo de aprender e paixão pelos livros. Ele com tanto esforço, tanto carinho, tanto amor desde o primeiro caderno até o ingresso na Universidade de São Paulo: o mesmo cuidado, o mesmo carinho, o apoio e o mesmo alerta "primeiro os estudos...". Vocês são minha razão de estar aqui, condição primeira para a realização desse momento.

Ao Donizetti, que me fez acreditar que eu podia chegar até aqui. A força, o carinho, a ajuda, as discussões e o apoio, não serão jamais esquecidos. Ao meu tio, Marco Antônio Marcelino (in memoria) professor exemplar de letras, muito conceituado por seus professores e colegas de profissão, que ficaria muito feliz... Aos que me ajudaram quando eu cheguei na Universidade de São Paulo, agradeço pela ajuda, pelas dicas, pela parceria e indicações e soluções sempre muito pontuais.

Ao professor Dr. Osvaldo Humberto Leonardi Ceschin, pela orientação precisa- e o apoio no desenvolvimento e na conclusão da pesquisa.

Aos professores: $\operatorname{Prof}^{\mathrm{a}} \mathrm{Dr}^{\mathrm{a}}$ Simone Rossinetti Rufinoni e Prof ${ }^{\mathrm{a}}$ Dr. Ariovaldo José Vidal, por suas contribuições e sugestões, por ocasião do Exame de Qualificação.

Agradeço à professora Dra. Regina Michelli UERJ/ UNISUAM - pelas conversas e sugestões contribuindo com muitas ideias para a pesquisa.

À ajuda e à atenção dos funcionários da Biblioteca Nacional e aos funcionários da Divisão de música do Palácio Gustavo Capanema, FFLCH, ECA, IEB, UFRJ (Letras e Geografia) UERJ e Museu da Imagem e do Som (MIS) da capital fluminense, onde fui muito bem atendida, com atenção, paciência e bom humor. Agradecimentos que se estendem também à Roseli de Fátima no departamento da letras, Thiago e Normando na sessão de informática pelos "socorros" imediatos.

Aos amigos, que contribuíram de forma direta e indireta para a concretização deste trabalho: a Fábio dos Santos Cruz e Nilva Lúcia dos Santos que me acolheram com carinho nas muitas vezes que estive no Rio de Janeiro, a Eliane da Silva e Nefatalin Gonçalves pelos conselhos de estímulo e motivação, aos amigos Jefferson Januário dos Santos, Luanda Dessana e Renné Trindade, pelo acolhimento inicial em São Paulo. À Josileide Terto agradeço pelas experiências que pude viver graças, à confiança que depositou em mim.

A Deus, a Nossa Senhora e a São Cristóvão que me guiaram entre Rio e São Paulo. 


\section{RESUMO}

PINTO, Sandra Regina Marcelino. Na roda de samba eu sou bacharel: análise de 21 canções de Noel Rosa. 2001. p.143 Dissertação (Mestrado) - Faculdade de Filosofia, Letras e Ciências Humanas, Universidade de São Paulo, São Paulo, 2011.

Esta dissertação trata de analisar, em vinte e uma canções de Noel Rosa, os seguintes traços que se encontram nas obras do autor: estilo autobiográfico, o feminino, o "seu" Rio de Janeiro, a sátira social, a filosofia na letra do samba, o humor e a crônica. Trata-se de um estudo de interpretação de músicas, que busca oferecer subsídios para conhecimento do valor temático encontrado nas canções de Noel Rosa e os acontecimentos das décadas de 1920 e 1930, os quais apresentavam ligações com as composições do sambista. A análise é feita classificando as canções por meio dos temas identificados nas músicas, sendo escolhidas três canções para cada grupo temático. Original em suas criações e destaque para sua época, o músico Noel Rosa marca seu discurso na composição popular atento aos fatores sociais, cotidianos e destaca o samba pela geografia do Rio de Janeiro, com humor e em muitos momentos de forma filosófica, este também menciona muitas vezes fatos de sua vida em seus sambas. Referência para sua época, Noel marca seu período histórico como o maior compositor do Brasil, chegando a marca de compor 259 sambas em apenas sete anos, o que lhe confere, conforme Máximo \& Didier (1990) e outros pesquisadores o título de maior compositor brasileiro.

PalaVRas-ChaVe: Interpretação de texto. Música Popular Brasileira. Noel Rosa. 


\begin{abstract}
PINTO, Sandra Regina Marcelino. In samba I'm BA: analysis of 21 songs by Noel Rosa. 2011 p.143 Thesis (MA) - Faculty of Philosophy, Letters and Sciences, University of São Paulo, 2011.

This dissertation is to examine in twenty-one songs by Noel Rosa the following traits found in the author's works, autobiographical style, the feminine, "its" Rio de Janeiro, the social satire, philosophy in the lyrics of samba, mood and chronic. It is_a study of music interpretation, which seeks to provide insight to know the amountfound in the theme songs by Noel Rosa and the events of the 1920s and 1930s, which had links with the compositions of the samba. The analysis is sortingthrough the songs of the themes identified in the songs, three songs are chosenfor each theme group. Original creations and their emphasis on his time, the musician Noel marks his speech at the popular composition attentive to social factors, lifestyle and geography highlights the samba of Rio de Janeiro, with humor and many moments of philosophical form, it also mentions often facts of his life in his sambas. Reference to his time, Noel marks its historical period as the greatest composer of Brazil, reaching the milestone of 259 sambas composed in just seven years, which gives, as Max \& Didier (1990) and others have the title of greatest Brazilian composer .
\end{abstract}

Keywords: Interpretation of text. Brazilian Popular Music. Noel Rosa. 


\section{SUMÁRIO}

INTRODUÇ̃̃

1

AONDE O SAMBA É DA COROA ……………………………………………. 12

1.1 QUEM NASCE LÁ NA VILA ............................................................. 12

1.2 O SAMBA NA REALIDADE NÃO VEM DO MORRO NEM LÁ DA CIDADE............ 16

1.3 A POPULARIDADE DA MÚSICA E A MÚSICA POPULAR BRASILEIRA................. 22

1.4 A MARCA DA FORÇA REPRESENTATIVA DO RÁDIO NA DÉCADA DE 30.......... 27

2

NA RODA DE SAMBA EU SOU BACHAREL .................................... 30

$2.1 \quad$ NOEL ROSA E SEUS TEMAS............................................................... 30

2.1.1 A AUTOBIOGRAFIA NA COMPOSIÇÃO DE NOEL ROSA.................................... 35

2.1.2 A REPRESENTAÇÃO DO FEMININO …................................................. 38

2.1.3 NOEL ROSA E O RIO DE JANEIRO …................................................... 42

2.1.4 NOEL ROSA E A SÁTIRA SOCIAL.............................................................................. 45

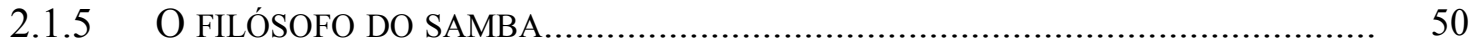

2.1.6 O ESPAÇO DA COMICIDADE NA OBRA DE NOEL ROSA................................ 52

2.1.7 A CRÔNICA EM FUNÇÃO DA MPB................................................................ 55

2.2 É BRASILEIRO JÁ PASSOU DE PORTUGUÊS ............................................. 56

2.3 A CONTRIBUIÇÃO DE NOEL ROSA PARA O SAMBA E O AMOR PELO 60

3 O SAMBA NÃO TEM TRADUÇÃO

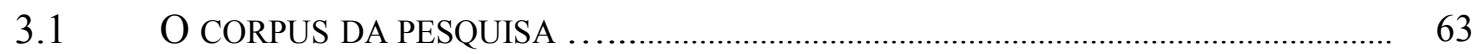

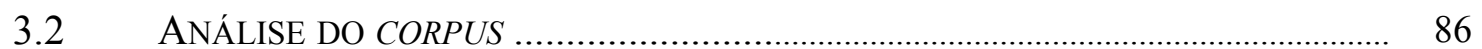

3.2.1 NOEL POR ELE MESMO: OS TRAÇOS BIOGRÁFICOS NA MÚSICA DE NOEL 86

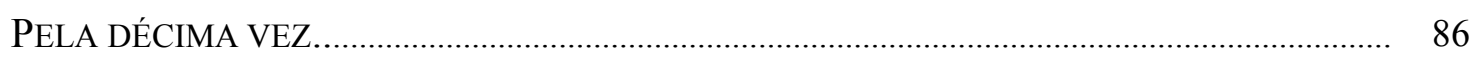

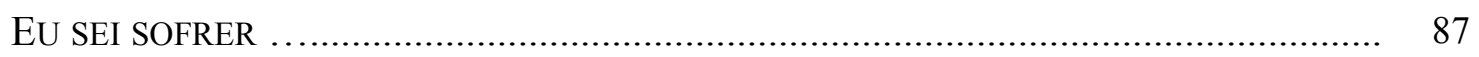

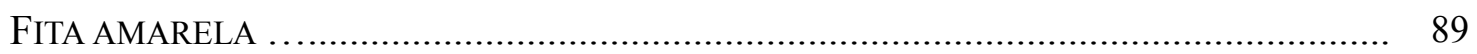




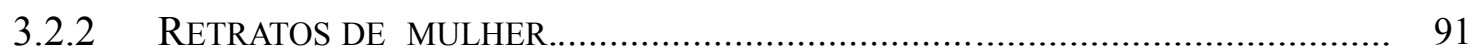

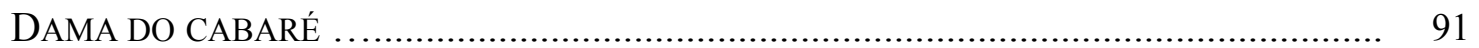

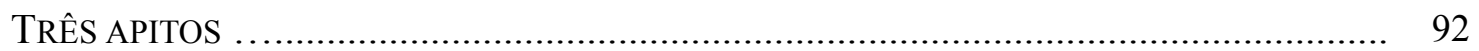

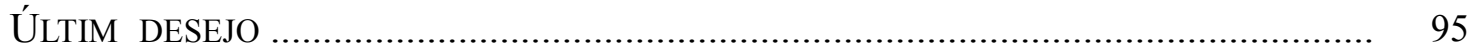

3.2.3 A EXPRESSÃO DE AMOR PELO RIO DE JANEIRO E PELA VILA ISABEL.............. 96

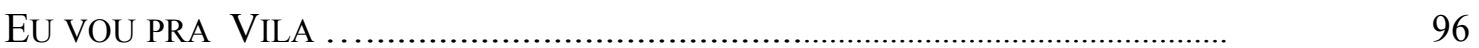

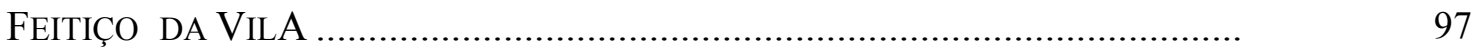

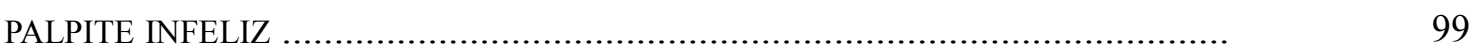

3.2.4 O OLHAR VOLTADO A SOCIEDADE DE 30............................................ 100

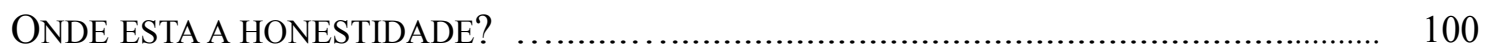

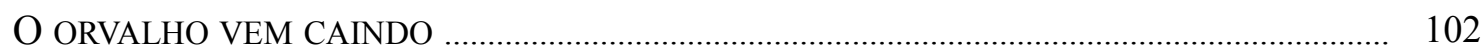

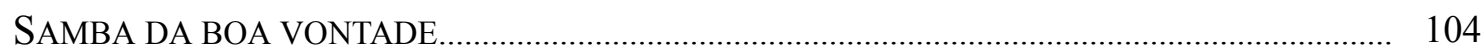

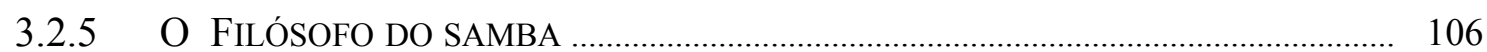

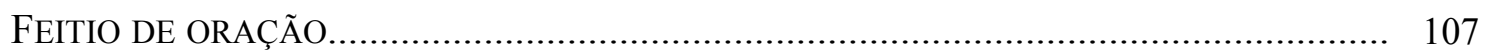

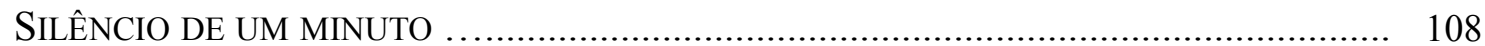

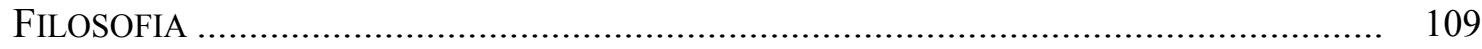

3.2.6 O ESPAÇO DA SÁTIRA NA OBRA DE NOEL ROSA............................................. 112

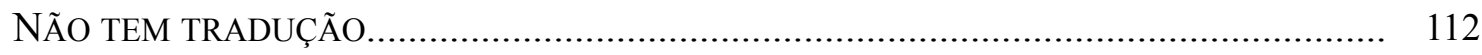

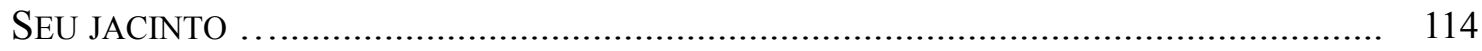

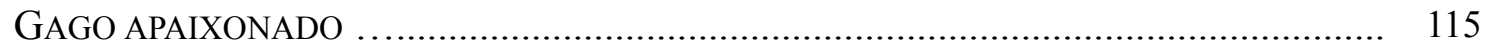

3.2.7 A CRONICA EM FUNÇÃO DA MÚSICA BRASILEIRA............................................. 117

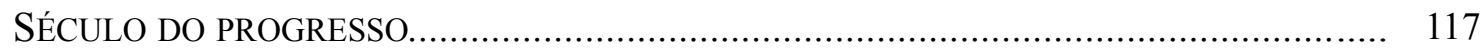

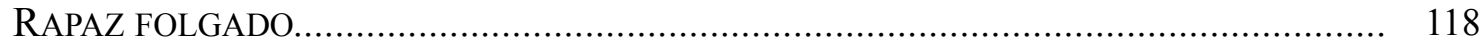

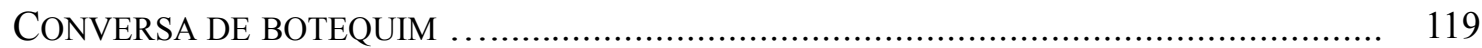

3.3 A COMPOSIÇÃO DE NOEL ROSA.................................................................... 122

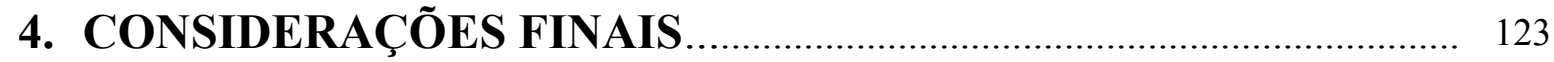

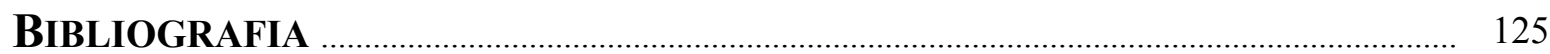

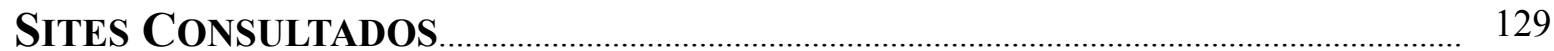

ARTIGOS E DOCUMENTOS …............................................................. 130 


\section{ANEXOS}

ANEXO 1 CARTA PARA A PRIMA CÉLIA........................................................ 131

ANEXO 2 MAIS UM SAMBA POPULAR.......................................................... 132

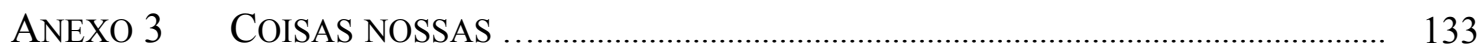

ANEXO $4 \quad$ LENÇO NO PESCOÇO.......................................................................................... 134

ANEXO 5 MOCINHO DA VILA........................................................................................ 135

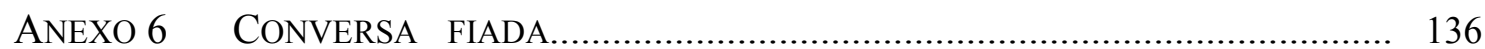

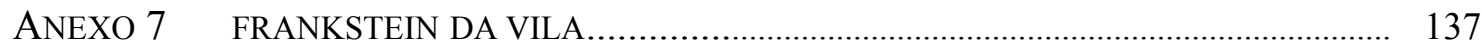




\section{INTRODUÇÃO}

Ninguém foge ao seu destino.

Eu sou um exemplo:

quiseram que eu fosse médico e eu acabei sambista... ${ }^{1}$

Esta pesquisa visa analisar a canção do cantor e compositor Noel Rosa. A escolha deve-se ao destaque e relevância de suas composições para a música popular brasileira. $\mathrm{O}$ repertório do compositor delimita o contexto social e político da época. Seu grande talento, altamente produtivo, como atestam Máximo \& Didier (1990), lhe conferem a autoria do maior número de canções registradas.

A importância do autor não se deve somente à quantidade, mas à qualidade de das composições. No curto período de uma carreira de sete anos, chega ao rádio com marcante participação em programas importantes na época, esse era o grande desejo de todo compositor e cantor da época. Principalmente para os que desejavam sair do amadorismo e profissionalizar-se gravando suas composições e firmando contrato com gravadoras e programas de rádio. Gravado por ele mesmo e por outros cantores, seu sucesso era sempre de grande proporção mediante sua interação com o povo. Compunha para o povo. Em suas canções, pode-se perceber, sobretudo nas que aparecem um "coro" a marca da voz da população.

Como Noel morre no primeiro momento da vertiginosa transformação de elementos especiais em diversas facetas vida cultural, sobretudo, no amplo aspecto da MPB, ele é um dos que representa o primeiro momento de notável expansão da música popular sob a chancela dos meios de comunicação de massa. Como explica Leitão (2009,p. 87) o veículo e o produto que ele difundia - a rádio e a canção - eram um par quase perfeito, sobretudo porque se dirigiam a um púbico de precária escolaridade, cuja escassa cultura letrada seria historicamente compensada por múltiplas e ricas tradições orais

A originalidade e a irreverência também se fazem presentes na forma de compor. Noel em muitos pontos de sua biografia se mostra afeito pela linguagem do povo, pela linguagem coloquial e pelas marcas de oralidade registradas em seu discurso. Noel vive na época do início do cinema falado, sente na época incisivas influências americanas e francesas sobre a população brasileira e louva tudo que considera ser coisas nossas .

\footnotetext{
${ }^{1}$ Entrevista ao Diário Carioca in Máximo \& Didier 1990, p. 165
} 
O trabalho analisa sete temas presentes nas composições de Noel Rosa. Para pesquisa , a elaboração e organização do corpus se apresenta da seguinte forma: canções de caráter autobiográfico - "Pela décima vez", "Eu sei sofrer" e "Fita amarela”; destacam o feminino: "Dama do Cabaré", "Três apitos" e "Último desejo"; o pelo Rio de Janeiro e a geografia do samba carioca, encontram seu espaço em: "Eu vou pra Vila", "Feitiço da Vila" $e$ "Palpite infeliz" entre tantas outras; para representar a visão de crítica à sociedade de sua época, as composições: "Onde está a honestidade?", "O orvalho vem caindo" e "Samba da boa vontade"; ainda em vida, reconhecido como "Filósofo do samba", foram selecionadas para as delimitações deste epíteto as canções: "Feitio de oração", "Silêncio de um minuto" e "Filosofia"; o humor, em diversas composições aparece aqui cita-se: "Não tem tradução", "Seu Jacinto" e "Gago apaixonado"; a marca do compositor inovador e inspirado em sua visão de mundo e do cotidiano, apresentando a música como crônica, é o que se pode apreciar em: "Século do progresso", "Rapaz folgado" e "Conversa de botequim”.

Como se pode comprovar ao apreciar as canções, não há unicamente um perfil exclusivo em cada letra, entre as escolhidas para investigação e no conjunto de sua obra. Divididas em eixos temáticos, ressaltamos traços escolhidos no qual o trabalho concentra a interpretação das letras presentes no corpus.

A pesquisa, para melhor contextualizar a biografia, sua época: o Brasil e o Rio de Janeiro de seu tempo e mediante esses pontos propor melhor compreensão das canções selecionadas, propõe dividir o estudo em três partes, para melhor desenvolvimento da dissertação.

Para iniciar, apresenta-se uma sintética biografia do compositor em questão contextualizando o seu envolvimento com o samba e também observar as particularidades do ritmo na época. É o momento do primeiro samba gravado no Brasil. E a popularidade da música popular brasileira já aparece graças a influencia do rádio no final dos anos 20 e 30 também são ojetos de nossa introdução.

Na segunda parte são descritas algumas considerações sobre os temas presentes na obra de Noel Rosa: composições de cunho autobiográfico, a figura do feminino nas letras do compositor, sua visão do Rio de Janeiro com ênfase nos redutos / berços de samba, o exame minucioso da sociedade da época - sobretudo no referente à postura dos políticos - seu epíteto de filósofo do samba, o espaço da comicidade na obra de Noel Rosa e o cotidiano do cronista musical Noel Rosa. 
Esse conjunto se compõe ainda de comentários sobre sua contribuição e importância para o samba e sua inovadora forma de elaboração de seus sambas.

A terceira parte, compreende os estudos desenvolvidos por meio das canções noelinas. As interpretações são feitas seguindo os tópicos temáticos com base na época, questões biográficas e apontamentos propostos pela bibliografia.Levam-se em conta os temas das músicas noelinas e os depoimentos de amigos e pessoas que conviveram por Noel.

O samba é o universo de Noel Rosa onde se encontram os bambas ${ }^{2}$, malandro, o cabaré, os bairros do Rio de Janeiro, a crônica e tantos outros elementos ao seu redor, lhe suscitam música, lhe permitem criar mais um samba popular ${ }^{3}$.

Entre os anexos, estão uma carta citada no texto de Noel para sua prima Célia, músicas que não compõem o corpus, mas são em algum momento mencionadas como relevantes para a compreensão de alguns pontos discutidos sambas de Noel e de Wilson Batista. 


\section{AONDE O SAMBA É DA COROA ${ }^{4}$}

\subsection{Quem nasce lá na Vila ${ }^{5}$}

A genialidade de Noel Rosa inspirou várias biografias, por esse motivo, não é intenção deste trabalho expor dados minuciosos sobre o autor das composições em questão ou propor algo revelador sobre ele, mas sim tratar da compreensão de suas composições, de "seu Rio de Janeiro". As informações sobre sua biografia aparecem para melhor favorecer a compreenção de sua obra. Trata-se, tão somente, de uma ajuda para propor subsídios que posteriormente auxiliarão a compreender várias questões biográficas que apareceram em suas letras.

São inúmeras as narrativas, experiências e os episódios que o levaram a se tornar uma das peças chave da música popular brasileira no século XX tal qual conhecemos hoje, e é este conjunto que tentaremos apreender neste momento.

Nasce no Rio de Janeiro, na então capital do Brasil, à Rua Teodoro Silva, bairro Vila Isabel, no dia 11 de dezembro de 1911 o primogênito da família, que recebe por nome Noel de Medeiros Rosa. Seu nome foi escolhido pelo seu pai, Manoel Garcia de Medeiros Rosa, por estar próxima a celebração do natal.

O menino se chamará Noel. Noel de Medeiros Rosa. Por ter nascido às vésperas do Natal e pelo amor do pai às coisas da França, o idioma, a cultura, a história do país de Bonaparte. (...) Noel como o Natal dos franceses. " (Máximo \& Didier 1990, p. 25)

Martha de Medeiros Rosa, sua mãe, teve um parto difícil, e Noel teve que ser arrancado a fórceps, o que lhe ocasionou um afundamento e fratura do maxilar. Tal fato lhe causou uma paralisia parcial no lado direito do rosto. As tentativas de reversão desse processo foram frustradas, e nunca reverteram seu defeito no queixo, a ponto de ele mesmo, em suas auto-caricaturas, acentuá-lo. Essa marca tornava sua alimentação difícil, e dessa forma, manteve-se tímido em público em diversas ocasiões.

Quando ainda era pequeno, o pai torna-se chefe de equipe que cuida de loteamento de terras no noroeste paulista, agrimensor, numa fazenda de café em Araçatuba, interior de São Paulo, onde permaneceu por seis anos (vindo para casa somente a cada dezembro, aniversário dos filhos) trabalhando assim, para pagar dívidas. A mãe abriu uma escola em sua própria

\footnotetext{
4 Verso da música Eu vou pra Vila da composição de Noel Rosa
}

5 Verso da música Feitiço da Vila da composição de Noel Rosa 
casa, no bairro de Vila Isabel, emprego que sustentará seus dois filhos — o menor, Henrique, nascera em dezembro de 1914.

Noel foi alfabetizado pela mãe e, aos 13 anos, entrou para o colégio Maisonnette, cursando depois o tradicional colégio São Bento, onde ficou até 1928; os colegas o apelidaram de "Queixinho". Foi aluno também do Colégio Pedro II, deixando muitas recordações aos professores e aos amigos, ao longo do curso, pois - como dizem - fícou várias vezes de segunda época.

Desde a adolescência interessou-se pela vida boêmia, aproximando-se cada vez mais da música e dos instrumentos. Começou a frequentar as rodas de samba, conforme era costume na região, por meio da convivência entre os moradores da zona norte carioca, devido as rotineiras rodas de samba organizadas nas noites de domingo nas casas de família da região.

Ainda pequeno, Noel aprendeu a tocar bandolim com sua mãe - mais tarde, com seu pai tem as primeiras lições de violão passando a ter preferência pelo segundo elegendo-o como seu instrumento particular.

\begin{abstract}
Noel inicia embalado por essas canções e tudo mais que se ouve em sua casa nas noites de domingo. A música logo o envolve, vira paixão das coisas mais importantes em sua vida. E não apenas o que se ouve nos saraus. Como ele mesmo confessará:

"Mesmo em guri, a minha grande fascinação era a música. Qualquer espécie de música. Fosse qual fosse. E amava os instrumentos musicais, sentindo-me sonhar ante qualquer melodia" (Máximo \& Didier 1990, p. 50)
\end{abstract}

Foi então, com violão que cedo tornou-se uma das mais conhecidas figuras da boêmia carioca. Como era planejado por sua família, para seguir uma tradição, o futuro cantor ingressou na Faculdade de Medicina. Mas diante da vida de artista, logo o projeto de estudar mostrou-se pouco atraente em meio ao samba e noitadas regadas à cerveja, causando preocupações a sua mãe.

No ano de 1929, terminado o ginásio, preparou-se para entrar na Faculdade de Medicina, sem deixar de lado o violão e as serenatas, sendo seu nome, nessa época, já bastante conhecido no bairro de Vila Isabel. Sua popularidade lhe permitiu um dia ser convidado para tocar no conjunto "Flor do Tempo ${ }^{6 "}$ posteriormente, "Bando de Tangarás"7,

6 Conjunto musical composto por: Henrique Foréis Domingues, o Almirante - 21 anos; Braguinha, ou , Carlos Alberto Ferreira Braga - 22 anos (posteriormente adota o nome de João de Barro ao ingressar no Bando de Tangarás) e o mais velho; Henrique Britto - 19 anos ; Álvaro de Miranda Ribeiro, o Alvinho - 19 anos, é o que vem procurar Noel. O grupo formado há três anos para exibições em residências, espetáculos amadoristas e festivais beneficentes. (Máximo \& Didier 1990, p. 101 a 103)

7 O bando de Tangarás, conseguiu gravar mais pela disponibilidade das gravadora do que pelos seus méritos, embora estes sejam discutíveis. (...) A palavra "tangará" não era estranha ao meio artístico do Rio de Janeiro. 
composto por: João de Barro (o Braguinha), Almirante, Alvinho e Henrique Brito. Porém, Noel não se sente livre para criar, para interpretar:

... percebe que, em matéria de música popular, há um tesouro escondido em algum lugar.(Máximo 1990, p.119)

Noel ainda não possui experiência, mas tem inspiração, e capacidade criativa. No grupo destaca-se como compositor e isso o atrai cada vez mais e mais para à noite, para festas e madrugadas fora de casa. A preocupação de dona Marta cresce, pois sabe que o filho cuida da saúde. Pedia-lhe sempre - em vão - que não se demorasse na rua e que voltasse cedo para casa. E querendo impedir uma de suas muitas saídas, lhe deu ideia para um de seus mais consagrados sucessos. Sabendo, certa vez, que Noel iria a uma festa em um sábado, escondeu todas as suas roupas. Quando seus amigos chegaram para apanhá-lo, Noel grita, de seu quarto: Com que roupa ${ }^{8}$ ? - no mesmo instante a inspiração para seu primeiro grande sucesso, gravado para o carnaval de 1931.

O ano de 1933 foi uma época fecunda para o compositor, os registros de gravação somam mais de 30 músicas gravadas. São muitos sucessos, incluídos na primeira fase da chamada "briga do samba" uma polêmica com Wilson Batista. Depois de algum tempo, a discussão musical sobre predileção por "seleiros do samba" gerou outras composições.

Noel casou-se com Lindaura, em dezembro de 1934, embora, no mesmo ano, numa noite de São João, em um cabaré da Lapa, tenha conhecido sua fonte de inspiração para vários sambas: Ceci. No mesmo momento fora tomado por uma paixão notória. Seu casamento, por imposição da mãe da noiva e intervenção da polícia que o acusava de sequestro de menores, Noel preferia ser preso a casar-se, mas não obteve êxito em seus planos ${ }^{9}$.

O casamento não alterou sua assídua presença nas noitadas no famoso bairro da Lapa, o problema é que a frequência de tantas noites no sereno comprometendo-lhe a saúde. $\mathrm{Na}$

O poeta, teatrológo, compositor e desenhista Luiz Peixoto havia criado, em 1927 uma companhia Tangará de Teatro.(...) Mas o Bando atingiu em ceio os consumidores de discos e ouvintes do Rádio e o público dos espetáculos. Foi realmente um sucesso. (Cf. Cabral 1990, p. 49 e 51)

8 Gravado por Noel Rosa em 30 de setembro de 1930 e lançado dois meses depois, sucesso arrasador. Além de muito cantado no carnaval de 1931, inspirou anúncios comerciais, paródias, charges, crônicas, entrevistas e até ajudou a fixar a expressão "com que roupa" como dito popular. Esta composição revela algumas características definidoras do estilo Noel Rosa, particularmente as que mostram seu humor extraordinário. (Cf. Severiano2008, 135)

9 Noel já conhecia Lindaura Martins, a Linda, como a chamavam, desde que ela fora aluna de sua mãe há algum tempo. Aos 17 anos, Lindaura era uma das namoradinhas que consentiam em sair ao seu lado no famoso Chevrolet (comprado de Francisco Alves) que ele apelidara de Pavão. Na noite de 12 de novembro 1933, um domingo, o Pavão levou Noel e Lindaura a um hotel na rua Senador Euzébio, perto da Praça Onze, onde o casal pernoitou. $\mathrm{O}$ fato desencadeou na vida dos dois uma verdadeira tempestade, com queixa de rapto à polícia por dona Olindina, mãe da moça, que a expulsou de casa afirmando que só a receberia de volta casada. Cf. Severiano2008, p.142 
mesma época, Lindaura grávida, perdeu o filho numa queda dos galhos de uma goiabeira existente no quintal do chalé. Solteiro ou casado, continua fascinado por Ceci e se entrega a um intenso caso de amor. Ao vê-la exercer sua profissão, sente-se angustiado por ciúmes ${ }^{10}$, mas não se afasta.

Em janeiro de 1935, examinado e radiografado, logo foi constatado que o paciente estava tuberculoso, obrigado a se retirar do Rio de Janeiro para tratamento, indo para Belo Horizonte MG, onde continuou com a vida boêmia, fazendo amizades em bares e no meio artístico da cidade, e foi convidado a apresentar-se na "Rádio Mineira".

São anos conturbados: problemas saúde lhe afastam do que ele tanto gosta, ou ainda, se pode dizer das coisas que ele mais gosta na vida: da boêmia e de Ceci. Como se não bastassem esses transtornos, estando ainda em Minas, no mês dê maio desse mesmo ano, recebeu a notícia do suicídio de seu pai, que se enforcou na casa de saúde em que estava internado para tratamento dos nervos. Com a morte do pai no mesmo ano, voltou para o Rio de Janeiro. Apresentando algumas melhoras, mas como não se cuida, os poucos quilos que ganha, se vão rapidamente.

Em fevereiro de 1937, por ordens médicas, para melhor eficácia no tratamento, viajou. Alívio da família mantê-lo longe da Lapa. Plano frustrado. Chegando em Nova Friburgo(RJ), continuava a frequentar os bares da cidade. Retornou ao Rio bastante adoentado. Como ainda não havia se recuperado bem, foi à Barra do Piraí, em abril do mesmo ano, em busca de repouso para tentar curar a tuberculose segundo sugestão de amigos e familiares.

Na manhã de 2 de maio, voltou ao Rio com Lindaura, às pressas, num táxi, em estado muito grave, do qual não conseguiria se recuperar, voltando praticamente moribundo para morrer na casa onde viveu toda sua vida, na noite de 4 de maio de 1937. Noel morou durante seus vinte e seis anos e meio de vida na mesma casa na Rua Teodoro da Silva. A casa onde viveu foi demolida, cedendo lugar a construção de um prédio residencial com seu nome.

Noel fica marcado como um compositor popular: sambas conhecidos e programas de rádio. Para a maioria dos artistas populares a fama acaba um dia após a morte, a dele só começou dez anos depois. É dessa forma que Tinhorão se refere a ele anos posteriores ao seu falecimento.

Um dos trabalhos mais completos sobre a vida do autor, a obra de João Máximo e Carlos Didier "Noel Rosa - Uma Biografia", marca uma triste ironia para com o autor que no antológico samba "Fita Amarela", após dizer que depois de sua morte não queria "choro nem $\overline{10}$ Ceci iniciou um romance com um rapaz ligado ao meio artístico chamado Mário Lago, que em breve iria se popularizar como ator e compositor. E para pirar a situação, Mario era jovem, solteiro, bem - apessoado e dedicava à dançarina um tratamento que ela jamais recebera de outros admiradores. Severiano2008, p.144 
vela", afirmara: "Não tenho herdeiros, não possuo um só vintém/ Eu vivi devendo a todos, mas não paguei nada a ninguém”. Essa obra é a mais completa biografia sobre o compositor e não pode ser reeditado, porque uma sobrinha decidiu embargá-lo judicialmente.

\section{2 "O SAMBA NA REALIDADE NÃO VEM DO MORRO NEM LÁ DA CIDADE"}

"De manifestação proibida a maior festa do mundo." É dessa forma que Moura \& Sant'Anna, (1998, p.34) apresentam o samba falando de sua trajetória por transformações urbanísticas da cidade do Rio de Janeiro onde nasceu Noel Rosa, perseguição e festa popular até chegar a escola de samba. Ritmo musical brasileiro, resultante de mistura de outros gêneros. Em sua "construção" estão inseridos ritmos africanos, e acredita-se que pode se chamar de evolução do samba: o lundu, o maxixe, até chegar ao que hoje temos por samba.

Sobre sua origem as opiniões se dividem: alguns acreditam que ele nasceu nos terreiros das senzalas, nos morros do Rio de Janeiro, outros entendem que ele surgiu na África foi trazido para a Bahia pelos escravos.

Desde seu surgimento, ele aparece como o que já "nasce discriminado". Em O livro de ouro da $M P B$, Albin apresenta um pouco do sofrimento testemunhado por depoimentos de: João da Baiana, Pixinguinha, Donga e Heitor dos Prazeres, pioneiros do samba. Estes eram presos nas ruas pelo "pecado de portarem um violão: coisa de desocupado, da negralhada". Eram também obrigados a entrar pela porta dos fundos do Hotel Copacabana Palace (RJ) por serem músicos e "ainda por cima negros".

O sambista sempre foi um sujeito socialmente discriminado e marginalizado. No final do século XIX, ao som do samba, descendentes africanos se reuniam. Discriminados por questões sociais, negros e mestiços constituíam a mais baixa classe da sociedade esse era o motivo de não haver interação étnica. Pereira (2001,p. 212) entrevista uma pessoa que se identifica como um mulato - escuro de 87 anos (portanto nascido aproximadamente em 1914) compositor carioca e fala sobre as festas ou como diziam, festa de samba:

“(...) Minha mãe sempre fazia festas para reunir meus colegas e amigos de origem. A festa durava às vezes dias e dias. Tinha comes e bebes e não faltavam o baile na sala de visita, o samba-raiado ${ }^{11}$ na sala dos fundos e a batucada no terreiro. Para fazer festa do samba minha

11 De acordo com o sambista e pesquisador Nei Lopes, o partido-alto era, no passado uma espécie de samba instrumental e ocasionalmente vocal (feito para dançar e cantar), constante uma parte solada, chamada "chula" (que dava a ele o nome de samba-raiado ou chula raiada). Fenerik, 2005, p. 215

“.tinha a chula raiada, que era o samba do partido alto. Podia chamá chula raiada ou samba raiado. Era a mesma coisa. Tudo era samba do partido alto." Tinhorão, 1998,p. 267 
mãe ia buscar o alvará na polícia. Lá o chefe dava conselho, pois a opinião da polícia, negro só se reunia para brigar, para fazer a malandragem. Mesmo com a autorização, a polícia não deixava a gente em paz. Ela aborrecia sempre. Quando a polícia "apertava" a gente num canto, a gente ia pra outro. Nós fazíamos samba na planície. Quando a polícia vinha, nos escondíamos no morro. Lá era fácil esconder. E por isso muita gente pensa que o samba nasceu no morro. Antes de ter morro habitado já havia samba. O morro era apenas esconderijo do sambista da cidade, da planície. Um dia de maio de 1918 eu estava na Penha, participando da festa do samba. A polícia veio, acabou com a nossa festa e ainda quebrou meu pandeiro. A polícia sempre tomava nossos instrumentos porque ela achava que preto era briguento, fazia capoeira e instrumento de percussão como arma. Ignorância!"

Mas como atesta Muniz Jr. em Do batuque à escola de samba, mesmo assim, a batucada espalhava-se pelos morros e subúrbios do Rio e cada lugar tinha seu grupo de "bambas". Mas a polícia estava sempre de olho, e quem andasse com um violão ou qualquer outro instrumento de samba era tido como vadio e logo atirado no chamado tintureiro, explica o autor, ser um carro onde seguem os presos da época.

Simultaneamente nesse período, os morros foram habitados pela camada mais pobre da população e esse fato faz compreender a presença recorrente do samba no morro e a razão de se manter tão presente neste espaço social, com a abolição da escravatura, os então denominados ex-escravos, saídos principalmente da Bahia, se dirigem a capital fluminense para procurar emprego e buscar melhores condições de vida. Como moradia, encontraram espaço instalando-se em morros, viviam longe do centro nobre carioca. É dessa forma que o samba tem sua concentração no morro. A partir de meados de 1915, sambistas como Marçal, Pixinguinha, Ismael Silva, Bidê, Donga, Elói e Nilton Bastos conseguiram consolidar o chamado "samba de morro"12".

Sant'Anna em “Música popular e moderna poesia brasileira” (1986,p. 183) mostra a relação do movimento modernista por meio de identificação com a época desde a gravação do primeiro samba (1917). Realizava-se em São Paulo a Semana de Arte Moderna propondo um novo conceito de arte que atualizasse o Brasil em relação à Europa e ao mesmo tempo estivesse mais voltada para a realidade nacional.

Em diversos pontos do interior dos estados, ou ainda se pode dizer, em vários pontos do Brasil, se denominou samba vários ritmos, distintas danças populares regionais oriundas de batuque africano. No que se refere à dança em si, é fato que gradualmente, ela ao mesmo

12 Os morros do Capão, Favela, Mangueira, Salgueiro, Querosene, Babilônia, Formiga, do Pinto, pendura-Saia, e as estações da Penha, Brás de Pina, Meriti, Deodoro, Madureira, Lucas e outros lugares distantes foram redutos tradicionais de batucadas, bem como os bairros da Saúde, Lapa, Estácio de Sá e a célebre Praça Onze, bem no centro da cidade. Cf. Muniz Jr. 1976, p.86 
tempo, dissolveu-se em ritmos populares e se caracterizou naturalmente como uma dança brasileira.

\begin{abstract}
Mais que um gênero, o samba é a própria identidade musical brasileira. Apesar disso, sabe-se pouco de sua origem, o que alimenta diversas hipóteses sobre fatos e circunstâncias que favoreceram o seu surgimento. De qualquer forma, desde 1870, pelo cruzamento e influência recíproca do lundu e da polca, da habanera ${ }^{13}$, do tango e do maxixe, já apareciam composições que tendiam ritmicamente para o samba.
\end{abstract}

Sabe-se, também, que na Bahia, provável berço de seu embrião, a palavra samba já era usada para designar as festas de negros, em fins do século XIX. A ampliação do raio de ação do novo ritmo, deveu-se ao movimento migratório de velhas baianas festeiras em direção ao Rio de Janeiro. Entre estas tias como eram chamadas estavam a tia Ciata (cuja casa na rua Visconde de Itaúna, na Praça Onze, foi praticamente o centro de tudo), Tia Amélia (Mãe de Donga $^{14}$, oficialmente autor do primeiro samba gravado, "Pelo Telefone", 1917, o mesmo ano de "West End Blues", o primeiro jazz ) e Tia Priscilana (mãe do João da Baiana ${ }^{15}$, percursionista que acompanhava Donga e Pixinguinha, que alguns estudiosos consideram o maior nome da música popular brasileira em todos os tempos - algo como Luis Armstrong ${ }^{16}$ representa para a música americana), entre outras. (Salazar, 1996p.5)

Sendo o Brasil um país de diversas influências no processo de formação na origem da música popular brasileira - fator decisivo para a obtenção dos resultados da sequência das incorporações até mesmo de tradições estrangeiras - não se pode deixar de mencionar neste contexto a cultura indígena - que também considera a música em seus rituais religiosos, no cotidiano e celebração de crenças. Com a chegada da cultura europeia, foram incorporados outros instrumentos aos gêneros da música popular brasileira.

Porém, o samba, mais que uma dança, tem a sua função ritualística. Pereira( 2003, p.116) ao falar sobre um dos redutos do samba da cidade do Rio de Janeiro, o bairro Cacique de Ramos, traça um paralelo sobre: o samba, o terreiro e os ritmos urbanos. Elementos que constituem forte ligação dos ritmos com as religiões afro. A importância da dança, da valorização ritmica e da importância do movimento no culto e de seu valor como

13 A habanera é a primitiva adaptação brasileira dessa dança cubana. Também aliás conhecida por tango no Uruguai e na Argentina. Cf. Andrade, Mário. 1976. p. 85

14 Donga foi um dos que fizeram parte do conjunto Oito Batutas, a convite de Pixinguinha, grupo este que fez muito sucesso na França (Paris) e na Argentina, em 1922, tempos de festejos do primeiro Centenário da Independência do Brasil. Seu nome de batismo era Ernesto Joaquim Maria, mas gostava de assinar Ernesto dos Santos Cf Dicionário Cravo Albim: http:www.dicionariompb.com.br/donga/biografia acesso 20 de maio de 2011

15 João Machado Guedes, * Rio de Janeiro 17 de 1887 — + Rio de Janeiro, 12 de janeiro de 1974. Na infância frequentou as rodas de samba e macumba nos terreiros clandestinos cariocas. É tido como o introdutor do pandeiro no samba. Cf. Oliveira $(1998,85)$

16 Louis Daniel Armstrong - Nova Orleans, 4 de agosto de 1901 - Nova Iorque, 6 de julho de 1971.

Considerado a personificação do jazz. Cf. Teachout (2010) 
manifestação cultural e portanto identificatória do negro. Jongueiros, batuqueiros e todo o povo do candomblé se reuniam nas casas das tias e, dessa forma, os instrumentos dos principais sambistas estiveram intimamente ligados aos rituais religiosos:

\begin{abstract}
Fortemente ligado (na sua origem e história) às religiões afrobrasileiras para as quais o canto, música e dança são aspectos extremamente interligados e de valor fundamental - o samba nasce e desenvolve a partir do espaço dos terreiros; é de lá que ele sai para interagir com o mundo dos discos, da rádio, acabando por se tornar a "música popular brasileira por excelência"
\end{abstract}

O samba foi lentamente superando as restrições e preconceitos e se tornou uma marca registrada da cultura urbana, embora tenha existido em regiões suburbanas se caracteriza nos grandes centros, Rio, Salvador, São Paulo. Modalidade musical das grandes cidades e tornou nacional.

Sodré (1998) considera com relação aos contatos interétnicos um fator importante para o negro reforçar as suas próprias formas de sociabilidade neutralizando a desqualificação sofrida pelo negro no processo de industrialização, tecnológico, cultural e religioso.

Enquanto os modernistas faziam sua espalhafatosa pregação pelos jornais e teatros expondo uma plataforma estética, que iria influenciar a vida política e literária brasileira nos últimos 50 anos, ia-se configurando mais nitidamente na década de 20 uma linguagem diferente dentro de nossa emergente música popular e que se tornou cristalizada nas composições de Noel Rosa, Sinhô, Donga, Ismael Silva.

A linguagem do sambista ia se tornando independente da influência direta dos poetas literários. Em 1917, com a gravação de "Pelo Telefone", Donga efetiva o samba como gênero descendente do lundu africano. As modinhas, maxixes, polcas cariocas, tangos e outras formas musicais já haviam evoluído e se cruzado a tal ponto que já se misturavam à origem nobre de umas com o uso popular de outras.

As marchinhas e o surgimento das Escolas de Samba, foram os fatores geradores de um grande impulso para as gravações, Sinhô obteve grande sucesso com "Pelo telefone", se tornando o primeiro grande sambista que caracterizou o gênero como ritmo típico do povo carioca. A porta estava aberta para que surgissem os sambistas brancos, e entre os primeiros mencionam-se Noel Rosa e Ary Barroso. As rádios tocavam samba com mais frequência e a indústria fonográfica passou a prensar discos que foram bem aceitos pelo público.

A organização das escolas de samba, conforme Elias em $O$ samba do Irajá (2005), 
surgiu a partir do final da década de 1920, mas muito longe do que encontramos hoje nas agremiações. O autor apresenta a "Deixa falar", do bairro do Estácio de Sá como a primeira escola de samba, ou seja, os blocos são compreendidos na época como tal. Quanto à questão das agremiações, Zaluar \& Alvito (1998,p. 126) atestam que nos anos 30, não havia distinção entre blocos e escola, ambos se apresentavam de maneira muito simples, "Deixa Falar" (fundada no Largo do Estácio) e Mangueira, foram as pioneiras, surgindo em 1928, mas a consolidação das "escolas" ocorre somente na década de 1930.

O samba nem sempre teve um convívio fácil com as novas exigências que os desfiles das escolas de samba lhe impuseram. Estes, ao serem criados, necessitaram de músicas com características próprias, de ritmo acelerado, para poder conduzir os componentes durante o desfile, e de refrões fáceis, para serem repetidos. Nos primeiros desfiles, manteve-se um pouco da improvisação das rodas de samba, dos bares e botequins. Após o coro feminino que iniciava o desfile, vinha o samba improvisado. No concurso de 1933, havia um quesito chamado "poesia do samba", que julgava justamente essa improvisação. Mas, já em 1935 fora abandonado a pedido dos próprios componentes das escolas, que mostraram impossibilidade da improvisação nos desfiles carnavalescos. (Zaluar \& Alvito 1998,p. 126)

Ferreira (2004, p. 360) aponta as negociações do carnaval na década de 1920 quando ranchos (barracões de reduto do samba) e cordões aceitam progressivamente a nova organização carnavalesca em troca de reconhecimento de suas manifestações:

... que se beneficiaria do interesse do músico Noel Rosa pelas batidas do ritmo "marginal" praticado nos morros cariocas. Dessa vez eram as escolas de samba que perdiam uma certa "pureza original" de um lado para ganharem, por outro o reconhecimento e valorização advindos da sociedade brasileira como um todo. Ao "aceitarem" o que foi chamado então de "invasão da classe média", as escolas de samba cariocas davam um importante passo para o seu definitivo reconhecimento como instituição cultural nacional de um país que buscava se impor como um espaço de pluralidade e inclusão. (Ferreira 2004,p.360)

A metrópole carioca foi o núcleo de evolução da música popular brasileira, Tinhorão (1997, p. 20), ao falar sobre a história do samba carioca, identifica-o como um gênero de música popular, destacando-o como uma música urbana, ligada à classe baixa. O Rio de Janeiro, quando chegada a época do carnaval, fazia sobressair o samba contando com a presença dos baianos vindos das plantações de açúcar e das aldeias para a ocasião das festas anuais.

A dança, por meio da batida que contagiava, teve uma variação pelo país de acordo 
com as influências da identificação que obteve em cada região, em São Paulo e Maranhão, a aceitação do samba lhe incorporou características típicas: baião, coco, jongo. Na Bahia, como o berimbau se incorporou ao quadro de instrumento, vê-se hoje claramente no ritmo da capoeira: palmas na marcação do compasso, ritmo, ginga os elementos do samba. Outra "variante" do samba é a umbigada. Compreendida até mesmo para alguns como "samba de umbigada" como encontramos em Carneiro (1961), com maior unanimidade entende-se que seja uma dança esta que apresenta de mesma maneira variações nos estados onde se faz presente.

Inicia-se em 1930 uma das fases mais promissoras para música popular brasileira. O samba se diversifica e muitos sambistas, começam a compor toadas e canções, entre eles Noel Rosa. Esse quadro apresentou sutis mudanças com a chegada do às samba altas classes sociais urbanas na fase áurea do rádio destacando o nome de renomados sambistas. Um grande problema surgiu: para agradar aos ouvidos ricos e para obter melhor aceitação do público, as rádios mutilavam o samba, recheando-o de instrumentos de cordas, gerando com a tentativa de aproximá-lo do som europeu.

Uma resposta para as questões de transformação do samba, nos parâmetros da época (1910 a 1930) são as variações que transitaram entre, elemento de discriminação até sua exaltação como identificação nacional. "O mistério do samba" de Vianna (1995), faz refletir ainda sobre a inclusão de uma cultura à margem social, mais definitivamente na década de 30 :

\footnotetext{
Hoje, em praticamente todas as tentativas de se escrever a história do samba, é reproduzida uma mesma narrativa de descontinuidade,como se os sambistas tivessem passado por dois momentos distintos em sua relação com a elite social brasileira e com a sociedade brasileira de forma geral. Num primeiro momento, o samba teria sido reprimido e enclausurado nos morros cariocas e suas "camadas populares". Num segundo momento, os sambistas, conquistando carnaval e as rádios, passariam a simbolizar a cultura brasileira em sua totalidade, mantendo relações intensas com a maior parte dos segmentos sociais do Brasil e formando uma nova imagem do país "para estrangeiro (e para brasileiro) ver". (Vianna,1995, p. 28-29)
}

Para Vianna (1995), a adoção do samba como elemento central de símbolo nacional, pode ser explicada como parte do esforço de esconder ou conter a denúncia da discriminação racial e evitar o conflito aberto que surgiria da percepção clara dos mecanismos da exploração social e política.

De fato, isso ocorre no contexto político das décadas de 20 e 30, onde o samba aparece também como um elemento de contestação política, como encontraremos vários exemplos nas letras de Noel Rosa. Vianna (1995) interpreta a questão do samba em música nacional como 
algo antagônico, a cultura de popular passa a ser nacional, levando a perceber que a promoção do samba no rádio e na imprensa, em sentido ideológico, não dá conta de como o samba foi modificado e saiu do Rio para a Nação, em uma negociação entre mediadores culturais com interesses diferentes: intelectuais e músicos.

\subsection{A POPULARIDADE DA MÚSICA E A MÚSICA POPULAR BRASILEIRA}

Segundo Moura \& Sant'Anna (1998, p 13e14), a música no Brasil começa a se configurar como música popular a partir do ano 1550 com Francisco de Vacas, considerado o primeiro músico na evolução da música popular brasileira. No entanto, não se podia afirmar, ainda que esta seria uma música genuinamente brasileira. O que havia na verdade era uma série de incorporações de tradições estrangeiras.

Inicialmente, os portugueses chegaram ao Brasil e encontraram os ritmos produzidos pelos índios, usados em momentos informais, nos festejos e, principalmente, nos rituais religiosos. Periodicamente, esta música foi substituída por outras manifestações musicais, provindas da influência dos negros africanos, dos espanhóis, dos franceses e foi surgindo, assim, a sonoridade basicamente nacional. Ritmos como jongo, batuque, modinha, lundus e polcas foram ganhando feições brasileiras. Estes ritmos faziam parte do meio boêmio carioca no início do século XIX, os quais, nas gerações posteriores, foram sendo substituídos por novas tendências: o choro e o maxixe.

As décadas de 1920 e 30 foram fundamentais para a música popular brasileira. Como se encontra em relatos já mencionados, o desenvolvimento das escolas de samba, a força de comunicação e a importância adquirida pelo rádio juntamente com o incentivo do Governo aos compositores que divulgavam sua política são alguns dos fatores que contribuíram para esse fenômeno. Outro fator é a criação de obras compreendidas como clássicas: sambas e marchas de carnaval que até hoje são conhecidas.

A música, principalmente o samba, compunha, neste período, um importante elemento no projeto de consolidação da identidade nacional, implementado pelo governo de Getúlio, segundo Duarte (2003). O mesmo autor afirma que a institucionalização dos desfiles das escolas de samba no Rio de Janeiro, naquele momento, relegadas a espaços marginais da cidade (morros e favelas) era o espaço onde se configuraram como fenômeno importante. Tais escolas foram pouco a pouco inclusas em processo de cooptação, pelo governo. Processo que 
frutificou várias análises da história da música, justificando o caráter épico de sambasenredo, em que se destaca a exaltação da natureza e a cultura nacional.

Lugares diversos: bares, morros, terreiros outros onde o samba foi ganhando espaço. Em ambientes completamente abertos, ou ainda, em lugares de caráter usual. O povo via no samba uma dança popular, um gênero musical derivado de ritmos e melodias de raízes africanas, como o lundu e o batuque e outras influências, ou seja, uma música popular. Conforme Tinhorão (2005) a música pode ser destinada ao lazer urbano. O que favorece a "popularidade" da música brasileira na época do samba é o surgimento e o interesse na industrialização da música brasileira, do samba em si como um produto nacional. A música, no Brasil, tornou-se, de fato, um produto artístico de maior difusão na sociedade, principalmente a partir das décadas de 1920 e 30.

Albin (2003, p. 11) considera a história de nossa música popular como a história de muito preconceito da parte da burguesia - que afirmava ter uma cultura oficial - e pior ainda se forem músicos e negros conforme seus testemunhas: João da Baiana, Pixinguinha ${ }^{17}$, Donga e Heitor dos Prazeres lhe citaram problemas enfrentados por eles. Esses fatores marcam a época da profissionalização do músico.

Faz parte do processo de elaboração da música popular brasileira, a relação com as transformação urbana, a industrialização, as influências culturais na criação de ritmos, na formação política, passando por interferências: de misturas das cantigas populares aos sons de origem africana, fanfarras militares, músicas religiosas e músicas eruditas europeias. Ao falar no fator industrialização, não se pode esquecer da rápida circulação de ideias no ambiente urbano, o advento do rádio e do registro em disco.

Esse fato é mencionado por Haunssen (2005) sobre a ampliação da classe média e o contato estabelecido por ela com as classes baixas. Por ter influência na música popular, compreendida como um veículo privilegiado para a disseminação da identidade nacional, a música popular formulada a partir da perspectiva que considerava estratos inferiores da sociedade. Funcionava como meio de manifestação artístico e cultural para os dois grupos.

A música sempre teve papel relevante no rádio, desde
seu início. Na fase amadorística, na década de 20 ,
quando havia grande preocupação com o papel
educativo do veículo, muita música clássica, óperas,
saraus ao piano foram erradicados. Mas já na segunda

17 Alfredo da Rocha Viana Filho.(* Rio de Janeiro 23 de abril de 1897 - + Rio de Janeiro 17, de fevereiro de 1973) A sua passagem pela música popular brasileira foi tão longa quanto marcante. Compositor, instrumentista, orquestrador e regente, Pixinguinha. Foi flautista, saxofonista, compositor e arranjador. Cf. Sérgio Cabral p. 123, 1997 
metade da década começava a música popular brasileira a se fazer presente nas emissoras. Renato Murce criaria o primeiro programa folclórico do rádio brasileiro, com a apresentação de maxixes e chorinhos. Um desses, "O passarinho do Má"18, de J. Amorim, fazia uma crítica velada ao governo de Artur Bernardes. São dessa época também, os conjuntos que tocavam as músicas regionais " O Bando de Tangarás", comandado por Almirante, com a participação de Noel Rosa, João de Barro, Henrique Brito e Alvinho(...) Além de tocar em festas, cafés no carnaval, eles começaram a se apresentar no rádio.

A conjugação de rádios e cantores fez com que a música popular se popularizasse realmente. São dessa época Mário Reis, Francisco Alves, Castro Barbosa e Carmem Miranda. (Haussen 2001 p. 65)

Para Haussen (2003,p.35), o rádio brasileiro já nasceu educativo e cultural. Toda essa diversidade, com o crescimento e popularização do rádio nas décadas de 1920 e 1930, fez a música popular brasileira crescer ${ }^{19}$. Os autores da citação acima compreendem a época inicial do rádio brasileiro. Além do mais, como confirma Albin (2003 p. 79) o grupo do Estácio entraria para a história da $M P B$ como consolidador do ritmo e da malícia do samba urbano carioca, ao destacar a fase de 1920 a 1930 como fase áurea da música popular brasileira.

Para o crescimento da MPB, duas modificações essenciais se tornariam determinantes. Primeiramente a mudança de sistema gravação mecânica para a gravação elétrica, o que permitia o registro fonográfico de vozes de curta extensão, mas cheias da malícia que o samba exigia. A segunda foi o aparecimento e a espantosa expansão do primeiro veículo de comunicação de massa de nossa história, o rádio. Albin (2003 p. 79)

O que compreendemos como MPB vem passando por diversas fases. Em Noel Rosa Poeta da Vila , Cronista do Brasil, Leitão (2009,p. 72) apresenta a música popular, como motivo de forte preconceito. Explica esse fenômeno como mais que previsível em uma sociedade recém-saída do regime escravista mais longo das Américas, em que a cultura afroamericana continuava a ser perseguida e estigmatizada.

Os ritmos envolventes cultivados nos bairros mais pobres, nos morros e subúrbios onde vive a população negra e mestiça da cidade (sobretudo no próprio centro, onde se

18 Passarinho do Má Antônio Lopes de Amorim Diniz "Duque" 1927, 78 RPM - intérprete Francisco Alves

19 O popular está presente nesta segunda fase da evolução do rádio (a noção de popular está aqui ligada também à noção de público rádio-ouvinte e suas necessidades psicossociais) justamente com o conceito de comunicação massa, do seu enfoque e mecanismos da produção consumo, ligados à sociedade industrial que já se evidenciavam no início do Estado Novo. A música e a programação passaram a expressar o estilo de vida urbano, agora em ascensão o populismo que começava a vigir. Cf. Frederico 1982, p.57 e 58 
refugia boa parte das vítimas do "Bota-abaixo",desde a Cidade Nova até os Morros da Gamboa e da Providência, berço das primeiras favelas) espaço destacado pelo autor como local onde se canta e se toca samba, organizam-se rodas de batucada e nascente da mescla de novos gêneros.

Tanto prevalecem os instrumentos de percussão quanto no caso dos grupos de choro, Esse ritmo surge com base de violões, flauta e cavaquinho. Outro fator que escandalizava a sociedade é o fato de tocarem tambores com que se entoando pontos de macumba e estes eram severamente reprimidos pela polícia do então Distrito Federal. Sem falar no "obsceno" maxixe.

A diversidade de tantos ritmos, polcas, modinhas, lundus, marchas, marcha-rancho, a chegada do samba, ocasionou, na verdade, um processo de compilação de seus produtores, na intenção de consolidar o que pode-se chamar de objetivação de seus produtores e de apropriação no que se refere à sociedade. Esta apropriação deu alento a temas como: política, a questão da identificação de um (ou de vários) grupo(s) social(is). Novas formas no campo popular, divulgavam cantores como: Noel Rosa, Pixinguinha, Dorival Caymmi, Ary Barroso, Lamartine Babo, entre outros. Eles inauguraram a proposta: de samba, ritmo e letra. Dessa forma, com o surgimento das rádios, recém implantadas no país, conquistaram um público fiel.

Somando-se a todos estes fatores há o cenário da época: dificuldades financeiras, quebra da bolsa, a revolução de Trinta, o que Bethel (1999, p. 71) chamará de depressão mundial no início nos anos 20. Nesse período,os compositores, eram diferenciados como do morro ou da cidade e produziam sambas que refletiam o momento histórico, o contexto ao qual estavam inseridos. Expressaram suas angústias e seus desejos relacionados ao futuro do Brasil, e falaram de suas percepções acerca das transformações culturais que ocorriam na sociedade. Entre os sambistas que se preocupavam com os problemas do Brasil, priorizamos um nome: Noel Rosa.

Tinhorão (2003,p.44 e 45) menciona Noel surgindo para o rádio e para o disco iniciando no amadorismo, destinado a caminhar para a profissionalização, representada por esses meios, contribuindo para o surgimento de um novo estilo de samba, ou seja, música e letra destinadas a atender por sua forma estilizada, ao gosto da nova camada a que se dirigia.

O samba chega como um novo gênero, uma mescla aguçada pela criatividade de músicos profissionais. Não se pode atribuir a ele um caráter de criação folclórica ou totalmente popular, embora tivesse raízes nos ritmos preferidos pelos pobres (especialmente 
os negros) do Rio de Janeiro.

Sem desassociar das questões sociais, somando considerações sobre ritmos, Leitão $(2009,85)$ reflete sobre isso inferindo que estes genuinamente jamais prevalecerão por completo na MPB, até porque os moradores dos espaços marginais do morro e da periferia, celeiros de tantos gêneros inovadores, também provêm em grande parte dos grotões mais pobres do interior, sobretudo do sertão nordestino, trazendo consigo um vasto repertório de ritmos - como xaxado, o forró e o baião - que até hoje em pleno século 21 , são ingredientes do amplo pastiche musical que a pós modernidade instaurou.

A forte influência da música nordestina no início da carreira do Bando de Tangarás $^{20}$. A ascensão do samba , contudo, é um índice eloquente da significativa metamorfose espacial que se processa entre nós no decurso do século XX convertendo a nação rural da primeira metade deste no país urbano entre as décadas de 1960 - 1980, fenômeno este que não é prerrogativa única do Brasil, abrangendo na verdade várias regiões da América Latina e do Terceiro Mundo.

A MPB, enquanto prática musical, originária de modinhas e lundus, como tanto considerava Mário de Andrade, emergiu do samba urbano carioca das décadas de 30 e 40, agregou outros ritmos regionais, como o baião, nos anos 1950, passou pela bossa nova, tropicalismo e festivais da canção nos anos 1960, para consolidar-se enquanto categoria na década de 70 .

$\overline{20} \quad$ O Bando de Tangarás eram muito influenciados pelos ritmos nordestinos. Cf. Chediak, 1991 p. 52 


\subsection{A MARCA DA FORÇA REPRESENTATIVA DO RÁDIO NA DÉCADA DE 1930}

Sant'Anna (1986, p. 183) afirma que a primeira emissora de rádio, no ano de 1923, foi a Rádio Clube do Brasil. Isto evidentemente deu um impulso à indústria fonográfica criada desde 1902 com a gravação do lundu de Xisto Bahia - "Isto é bom". Ao lado da rádio e do disco, a comédia musical, ou melhor, o teatro de revista, que já existia desde a segunda metade do século XIX ganha, por volta de 1915, "uma estrutura tipicamente brasileira e carioca e estava pronto para lançar-se a uma nova fase: a da busca desenfreada de revistógrafos e compositores mais atualizados, e capazes de fazerem frente à enorme procura de textos e de músicas exigidas pelo sistema de "teatro por sessões".

No final dos anos 20, inicia-se uma série de manifestações culturais, criadas para conquistar segmentos sociais do mundo urbanizado, e vinculadas a uma nascente industrial ${ }^{21}$ gerando lazer e dessa forma nasce conquistando a população: o rádio, o cinema e a música popular. Souza ${ }^{22}$, em A fascinante aventura do cinema brasileiro (1981,p. 46 e 47) fala sobre o primeiro filme sonorizado, que foi produzido em 1932, Coisas nossas, com genial sambatítulo do jovem Noel Rosa. Era já predominante o gosto por músicas nos filmes.

Albin $(2003,12)$ fala sobre a inauguração do rádio e do trabalho de Roquete Pinto, apontando-o como um gênio e nome de destaque na formação do rádio brasileiro. Este instrumento de comunicação, desenvolvido pela esperteza política do estadista Getúlio Vargas, registrando dois momentos: o é primeiro a implantação do rádio no Brasil na data de 20 de abril de 1923, e no segundo momento a gravação elétrica (a partir de 1928) pontos primordiais para florescer a época da MPB. Os anos de 1930, já irrompiam talentos nos quatro cantos do país, especialmente no eixo Rio - São Paulo.

Segundo Bruhns (2000, p.158) o meio de comunicação atuante no processo de divulgação do samba, na década de 1930, foi o rádio, propagando-se por todas as camadas sociais urbanas, passando o samba a ser a típica música brasileira, com grande sucesso comercial.

Saroldi \& Moreira (2005, p.34) afirmam que os meios para essa divulgação do rádio, eram um "plano" de Ademar Casé que deu certo. Como estratégia, ele selecionava residências que tinham telefone, símbolo de status na época, visitando tais lares levando

\footnotetext{
21 Certos programas particulares degeneraram em indústria, explorada por espertalhões adventícios, sem ideal artístico. Aproveitaram-se da bondade ou da ingenuidade de chefes de casas comerciais, solicitando suas verbas. Os anúncios, jamais levando-os ao ar. Tornavam-se necessárias normas rígidas a fim de que fossem evitados maiores danos às emissoras e ao comércio. Cf. Almirante, 1977,p.95

22 Escritor e pesquisador de cinema.
} 
receptores, geralmente em horário de trabalho do chefe de família, sem qualquer compromisso. Contornando a resistência da dona de casa, deixava o aparelho alegando voltar dias depois, para recolhimento.

Dois ou três dias depois, passava por lá e já encontrava má vontade da senhora de desistir do rádio e acabava comprando. E assim eu vendi tanto aparelho de rádio que acabei sendo apresentado ao dr. Augusto Vitorino Borges, e aí eles estavam com a ideia de lançar uma estação de rádio para fazer propaganda dos aparelhos no Rio. ( Saroldi \& Moreira 2005, p.35)

Essa é a explicação de como Casé, sem jamais ter sido compositor, locutor ou músico, em 14 de fevereiro foi ao ar pela primeira vez em um programa batizado com seu nome: Programa Casé. Saroldi \& Moreira (2005 p.36) apresentam a Sociedade Brasileira Rádio Nacional que nascia ali como resultado da venda da Rádio Philips. Esta desistiu de ter emissora para incentivar a venda dos aparelhos receptores de rádio de fabricação própria. Dessa forma a política comercial da empresa holandesa visava, sobretudo conquistar o mercado brasileiro para os aparelhos de válvula de sua fabricação, embora nem sempre acessíveis aos recursos da classe média.

Frota (2003 p.17), afirma que Edgard Roquete Pinto dizia que o rádio poderia ter, com uma feição educativa de alguma maneira, regulada pelo Estado e por isso poderia servir ao país, como uma escola de analfabetos. Com o rádio, o cinema e a música popular começavase a viver, então, a chamada Era da cultura de massas.

Saroldi \& Moreira (2005 p.36) apresentam Noel Rosa como convidado para ser contra regra do famoso Programa Casé. Este com a ideia de anunciar um dos patrocinadores obteve grande êxito com o samba "De babado". ${ }^{23}$

Pereira (2001,p.217) afirma o consumo da música em escala reduzida restrito a: teatros, circos, cafés, cinemas, clubes. As próprias gravadoras não tinham o que ele define como "sentido econômico". Dentro desse contexto sociocultural, e nesse momento histórico surge o rádio, transformando-se aos poucos um instrumento da massa. Sendo este não só um entretenimento público, mas paulatinamente um novo setor de atividades remuneradas. Segundo Pereira, Noel Rosa afirma que ingressar no rádio era o ponto máximo das aspirações dos artistas.

Para a época, Noel pôde deixar seu recado com bom humor e qualidade retratando o Brasil e a sociedade conforme se pode conferir na análise de algumas suas letras. Com muito

23 De Babado Noel Rosa / João Mina 193678 RPM - intérpretes Noel Rosa / Marília Batista 
talento e estilo próprio, Noel se tornou um ícone que reflete sua influência em diversos compositores (inclusive de nossa atualidade). Entre a medicina e a música, Noel escolheu a segunda, assumindo sua paixão: o samba. Essa decisão leva-o a uma de suas "célebres" frases : " Prefiro ser um bom sambista a ser um mau médico. ${ }^{24 "}$ O Rio de Janeiro perdeu um médico, o Brasil ganhou um dos maiores sambistas de todos os tempos.

24 Cf. J. Muniz Jr. 1976, p. 154 


\section{NA RODA DE SAMBA EU SOU BACHAREL}

\subsection{NOEL ROSA E SEUS TEMAS}

Fiz um poema pra te dar

Cheio de rimas que acabei de musicar

Se por capricho

Não quiseres aceitar

Tenho que jogar no lixo

Mais um samba popular ${ }^{25}$

Caldas $(1995,32)$ apresenta Noel como um dos mais reconhecidos compositores da música popular brasileira e mediante esse fato considera: "em qualquer época que se realizar pesquisa sobre a cidade do Rio de Janeiro e sua cultura musical, o nome e a obra de Noel Rosa são imprescindíveis”. Noel Rosa é valorizado em diversos, estudos em vários aspectos: musical, linguístico entre outros e isso se dá por sua posição de destaque como compositor brasileiro. Se partirmos da ideia da comparação do trabalho de um poeta com o trabalho de um artesão, chegamos ao consenso de que ambos tem por mesmo objeto e buscam adquirir a melhor forma para ter êxito em sua criação.

$\mathrm{O}$ artesão utiliza todas as ferramentas para que a matéria tome a forma que mais the agrada, a que mais lhe parece bela. O poeta, o compositor, o criador literário trabalham como um artesão da palavra, e é na palavra que eles encontram a matéria-prima de seu trabalho; dessa forma, o trabalho do escritor, do compositor varia de acordo com as dimensões artísticas que cada um procura.

Wisnik (1989) em seu $O$ som e o sentido faz considera que a música é aquela que é "capaz de distender e contrair, de expandir e suspender, e condensar e deslocar aqueles acentos que acompanham todas as percepções.” (p. 29) Talvez seja essa a dimensão da música, ou ainda, ao referente a sua inspiração, a capacidade de compor de modo tão natural. Sua autoridade, lhe permitir confessar "já ensinei a fazer sambas..." ${ }^{26}$ Com certeza esse fato tem interferências nos atributos conferidos a Noel Rosa, pois o seu nome e seu sucesso contribuem para a valorização da música brasileira. 
Após o sucesso do samba “Com que roupa?” como atestam Máximo \& Didier (1990): "Noel Rosa começa a ser agora - e será sempre - um compositor temático, tudo ou quase tudo partindo de um motivo central, um tema." ${ }^{27}$ esse registro ajuda a compreender suas letras e os epítetos que lhe aplicava o povo: "poeta da Vila"28", "filósofo do samba" sem deixar de lado a aguçada e minuciosa atenção aos problemas de aspecto social presente em suas composições.

Os temas aqui apresentados são universais, podendo ser encontrados em qualquer cultura, porém, o que desperta a atenção é a visão social de sua época, suas reflexões sobre o amor e a mulher explorados várias vezes em contexto subjetivo. Já em relação a sua capacidade de ver a vida e a sociedade de sua época, a sociedade é o de delimitação em que o humor se faz presente, mas é enfático ao apontar sua opinião. O mundo ao seu redor, é fonte de inspiração, a descoberta do cotidiano lhe traz revelação assim como seu amor pela cidade do Rio de Janeiro, partindo desses e de outros pontos ele fecundou sua obra para transformála em melodia e poesia.

Ainda sobre seus temas, Albin (1997) afirma que "sua vida foi quase toda registrada em seus sambas. Difícil é encontrar uma música que não poderia mesmo passar despercebido que não tenha história específica ${ }^{29 "}$.

O recorrente tratamento de Noel Rosa como um poeta ${ }^{30}$, é de fato questionado por uns enquanto outros dão o parecer de essa discussão ser um fato inquestionável. Como letrista, Noel Rosa tem produção para lhe conferirem o título de "maior compositor de samba do Brasil ${ }^{31}$." Em apenas sete anos de produção musical, entre 1929 a 1937 ele chega a marca de 259 sambas como se pode conferir em sua mais completa biografia ${ }^{32}$.

Dessa forma, por ser um letrista muito produtivo, suas rimas e seu jeito de compor, vários autores afirmaram dão às suas composições o status de poesia, entre eles, Castelar \&

\footnotetext{
27 Máximo \& Didier 1990 p. 130

28 A discussão sobre a posição que os poetas da música popular ocuparam no panorama da criação artística do século XX está em aberto. Uma análise da obra completa dos compositores mais notáveis iria, certamente, revelar algumas insuficiências do ponto de vista literário, mas muitas letras de canção poderiam figurar, sem nenhum favor, ao lado dos melhores textos poéticos contemporâneos. A presença de figuras literárias no surgimento da canção popular é mencionada de estudos históricos tanto de literatura quanto de música popular. A discussão naturalmente se volta para a Idade Média, quando toda a poesia era ainda cantada. Cf. Perrone 1988, p.13

29 ALBIN 1997, p. 36

30 Embora haja divergência entre autores ao conferir-lhe este "título" popular de poeta. Severiano ao comentar algumas letras conclui todas elas conferirem uma amostra do talento musical do Compositor da Vila. Afirmando 'talvez' ser um exagero afirmar que o músico se iguala ao poeta. Não o é , certamente, se situá-lo entre os grandes melodistas da música popular brasileira. Embora o mesmo autor em alguns momentos lhe confira o tal tratamento. Cf. 2008,p.138 De toda maneira, esse é um título que lhe foi conferido pelo povo.

31 Almirante 1977, p. 213

32 A obra de Máximo \& Didier 1990 "Noel Rosa - uma biografia"
} 
Araújo (1999,p.117). A poesia diferente e renovadora, tanto em termos linguísticos quanto poéticos. Nesse sentido, sua obra se afina muito mais com os procedimentos formais do Modernismo do que com os da estética 'romântica parnasiana', comuns aos compositores contemporâneos do "poeta sambista"'.

Ari Barroso, em artigo publicado na Revista da Música Popular (nº11, nov. - dez. 1955), mesmo depreciando alguns qualidades de Noel, reconhece-lhe a autonomia e valor dos versos e afirma: "Noel era, antes de tudo, um poeta"33. Albin (1997), o apresenta como poeta dos versos despojados de preciosismo, o cronista de época mais precioso e enxuto, que traria para o começo dos anos 30 a simplicidade e o bom gosto, tão revolucionários como a Semana de Arte Moderna em $1922^{34}$.

Nesta mesma edição da revista, Ary Barroso declara ainda o fato de não contradizer a qualidade de Noel como letrista e aponta-o como coisa rara e afirma ainda a seu respeito: "Seu estilo nunca foi superado. Diamante de vários quilates, como compositor, venero a memória daquele que criou uma escola de poesia para o samba". ${ }^{35}$

Noel é apresentado como "o nosso primeiro poeta - compositor modernista ou, pelo menos, com fortes tendências modernistas. Na verdade, pensamos ser irrelevante a preocupação em saber se ele criou sua obra originalíssima movido por uma espécie de intuição inata ou se o fez de forma consciente e deliberada, com pleno conhecimento prévio das propostas renovadoras do Modernismo." "36 A escola modernista aponta destaque à composição inovadora, como é o caso de Noel Rosa, encontrando desse maneira, prontamente do povo, o reconhecimento de poeta popular pela sua originalidade de composição.

33 Cf. Severiano2008, 136 e 137

34 Cf. Albin 1997, p. 35 e 36

35 Na revista da Música Popular Brasileira no 11, dezembro de 1955 - apud Vida Musical de Mariz Vasco 1997, p. 125

36 Cf. Carvalho \& Araujo 1999, p.118

Enquanto São Paulo, industrial, fez o Modernismo de 22, agressivo e antropofágico, influenciado pela Vanguarda Francesa, no Rio, o Modernismo foi feito, quase que solitariamente feito por Noel Rosa. Acreditase que Noel como Oswald de Andrade, ele também achava que a poesia estava nos fatos, só que enquanto São Paulo fazia o modernismo no trabalho, no negócio, Noel o fazia no ócio. Sem influência francesa, a grande poesia de Noel nascia ali no meio fio, no botequim, na mulata, no baleiro, jornaleiro, condutor e passageiro. Ele compõe no botequim, no orvalho que caia e os apitos da fábrica de tecido, vinham ferir os seus ouvidos, Noel parecia sentir uma infinita turbulência que viria, já defendia a inocência de um Brasil frágil. A bossa nova: Tom, João Gilberto, Caetano, Chico, toda grande música 
do país continuou a cantar toda essa delicadeza perdida. Nossa música extraordinária está de pé, mesmo em meio a vulgaridade industrial para massas, às vezes como uma utopia do passado, o que fora mencionado em "Coisas Nossas". ${ }^{37}$

Para Noel Rosa, a atualidade, a sua realidade, as dificuldades, o que sente na época, por meio de tudo encontrado no sofrimento comum, na indiferença do governo, esses acontecimentos lhe remetem a uma vertente de caráter social, e desde sua infância, à observação de seu olhar sobre os problemas sociais de seus amigos e dos acontecimentos em sua rua.

Se considerarmos que cada época tem seus grandes momentos sociais, seus grandes problemas, os relatos cotidianos jornalísticos seriam de forma suprema uma literatura demasiadamente importante e os que a relataram seriam para sempre lembrados. É preciso mais. Noel ultrapassa o que é contingente, indo além do que pertence a essa situação social histórica, desse modo, se atinge o atemporal, além do seu tempo. É com isso que ele consegue interessar a geração futura.

De toda maneira é inegável que o amor e os problemas do cotidiano interessam sempre, são universais, e ele atingiu esses pontos. Partindo do ambiente que vivia, os relatos da Vila Isabel, do Rio de Janeiro e da linguagem local, as gírias como encontramos em sambas como "A melhor do planeta"38. Suas personagens diversas das quais falremos porteriormente como encontramos na música "Pierro apaixonado" apresentação de um personagem de todos os tempos.

A música é uma marca que atravessa o tempo, é um elemento que pode por regravações se modificar sem alterações na letra deixando-a "fixada" por gerações. Soares (2002) define claramente o que se vê da voz expressa nas canções de Noel no que se refere a seus temas:

\begin{abstract}
O compositor do qual se fala, empresta-nos sua voz para cantar os mais diversos temas, incluindo, neste vasto catálogos de possibilidades o tema da canção e da nacionalidade brasileira. (Soares 2002, p. 13)
\end{abstract}

Sobre o que tratamos aqui como temáticas de Noel Rosa, averiguando como elas

\footnotetext{
37 Cf. Jornal da Globo - centenário de Noel Rosa - Youtube : Jornal da Globo: Noel Rosa completaria 100 anos em 2010 - 13de junho de 2011

38 "A melhor do planeta" - samba cheio de gírias de Noel Rosa e Almirante, Cidade Mulher - samba exaltando a cidade do Rio de Janeiro que Noel fez para o filme "Cidade Mulher"produção de Carmen Santos e direção de Humberto Mauro e Meu barracão - uma das manifestações mais cariocas de Noel. Espera mais um ano samba com jargões da época. Há ainda outros, mas estes são citados aqui somente para complementar a informação acima.
} 
aparecem nas canções escolhidas, tomadas como as que enfatizam destaque dos tópicos, há uma ligação de tais "facetas" fundamentadas originalmente no que pode-se compreender como pilares: social, amor e vida.

Severiano (2008,p.135) divide a trajetória da carreira de Noel Rosa em dois abrangentes segmentos: o amargo, pessimista, que trata das agruras do amor - paixões, ciúmes, traições - seu perfil autobiografico é realmente confessional, muitas vezes alegre, otimista, que faz a crônica do cotidiano, dos fatos pitorescos, além da exaltação de Vila Isabel, do samba e da "altivez com que tratava o samba ${ }^{39}$ " e de outras bossas de forma espirituosa, por vezes satírica e irônica.

O trabalho se compõe valorizando ainda outros fatores e tópicos de suas composições como: cultural, a valorização ousada e crítica da realidade brasileira, o contexto social e cotidiano em que encontramos seu destaque na elaboração de suas composições. Nesse âmbito, muitas vezes o conjunto de composições de Noel Rosa vem partindo de uma construção que nos faz refletir esse sentido de renovação e de valorização crítica do contexto nacional, como se pode encontrar em várias de suas canções, as questões do povo, do povo brasileiro como em "Coisas nossas. 40 " Para usar uma expressão do próprio Noel, se analisarmos alguns aspectos, verificamos, que em vários deles, se encontram características semelhantes as usadas pelos modernistas.

Apresentando compreensão da linguagem no trabalho de sua composição, pode-se afirmar que desenvolvendo um estilo de versos ligeiros, espirituosos e incrivelmente comunicativos. Noel assimilou, também, o estilo provocativo e irônico da imprensa da época, e chegou a composições que deram origem a canções de saborosíssimo paladar das crônicas sociais que encontraremos ao analisar algumas das composições apresentadas no corpus desta pesquisa.

Sobre a variedade e riqueza que encontramos na obra do compositor, traçamos uma apresentação detalhada sobre os tópicos temáticos como "introdução" do conjunto apresentado na análise das canções do corpus.

Em Noel Rosa encontra-se a identificação com o povo, ele se mostra crítico, se mostra irônico, mostra muito humor, muitas vezes apresenta o que é definido como humor negro daí a ideia de iniciar a análise de suas letras apresentando um pouco do compositor para compreender melhor a composição e o que ela explora.

Averiguando seus temas aqui mencionados, com enfoque específico em sete deles se

39 Tatit, 1996, p. 29

40 Autoria de Noel Rosa, 1932 
restringem em resumo a dois pontos: sua autobiografia onde por inúmeras circunstâncias aparecem questões ligadas ao amor (foram vários os seus casos com mulheres de diferentes lugares) e sua visão de sociedade brasileira especialmente do mundo urbano do rio de sua época, assim nos aproximamos da obra para conhecer a vida, um pouco da história, da biografia de Noel Rosa por meio de suas composições.

\subsubsection{A AUTOBIOGRAFIA NA COMPOSIÇÃO DE NOEL}

Máximo \& Didier (1990), apresentaram toda a obra de Noel ligada a sua biografia. O traço autobiográfico se revela em suas composições onde ele apresentava: o seu bairro, suas namoradas, seus desafetos, suas piadas e paixões, o cotidiano da cidade maravilhosa por meio de personagens que enriqueciam suas crônicas musicadas. Ele mesmo admitiu: "é assim que eu faço minhas coisas. Com situações, episódios e emoções, aspectos colhidos na vida real. $^{41} "$.

Shediak $(1991$, p. 8) atesta sobre sua originalidade justificando-a pela sua própria existência:

Ele nasceu diferente. E ser diferente faz você pensar diferente, sentir diferente, inventar. Noel era um original. Uma exceção. O que foge à regra. O contra regra, papel que the coube com exatidão nos primórdios da era do rádio. Criança ainda, encontrou a avó enforcada o quintal. Depois, foi o pai quem se suicidou. Com uma biografia dessas, só chorando. Ou rindo. Entre o riso e o pranto, Noel ficou com ambos. Entre o drama e a farsa, preferiu a tragicomédia - a dama e a graça.

"Noel, poeta da Vila" (2006), filme de Ricardo Van Steen, apresenta em uma das cenas, dois jovens sambistas do Rio de Janeiro, um branco e outro negro, em regresso da boêmia tão estimada das noites cariocas nos anos 30, chegam completamente embriagados em casa, com o dia raiando. A mulher de um deles, acordada e à espera no barraco da favela, ajeita os dois sentados dentro em uma bacia metálica, para levarem um banho frio de caneca e se curarem da bebedeira. A cena, que já foi relatada como verídica, mostra o grau de cumplicidade de dois gênios da música popular brasileira, o branco Noel Rosa e o negro

$41 \quad$ Máximo \& Didier 1990, p. 155 
Cartola $^{42}$, ícones absolutos do samba de sua geração. Noel e Cartola foram grandes parceiros, não somente nos excessos da boêmia, foi uma amizade fortalecida pelo ritmo do samba.

Compuseram juntos diversos sambas, mas muitos se perderam. Porém, o que conhecemos é o conjunto de verdadeiro patrimônio da música brasileira, fruto da formação da cultura e sociedade urbana do início do século XX.

... O encontro com a linha urbana de Noel resultou, em vez de choque, em uma soma de fatores que poria a Vila novamente, na ponta-de-lança do samba carioca: rural + urbano + calango + "samba da cidade" + firmeza política + leveza e humor. (Vianna 2004p. 91)

Noel morreu muito jovem, ainda no início do século XX, contudo entre suas quase trezentas músicas, algumas delas, regravadas e conhecidas até hoje. Em várias de suas composições há marcas autobiográficas fazendo transbordar seu cotidiano.

Pelas confirmações que encontramos em Carvalho \& Araújo (1999), não há escritor importante que não deixe transparecer em suas obras algum tipo de referência autobiográfica, velada ou explícita. Entre nós, Machado de Assis é um exemplo do primeiro tipo, com seus contos e romances de introspecção psicológica. Já Graciliano Ramos representa o segundo tipo, com suas amargas Memórias do cárcere, reminiscências pessoais e libelo acusatório.

No caso de Noel, este nos legou inúmeras informações autobiográficas através de seus sambas, e quase sempre na $1^{a}$ pessoa. Trata-se de mais um núcleo temático importante, que poderíamos classificar de Noel "ele-mesmo", e que merecia um estudo pormenorizado. Por ora, nos limitaremos a citar alguns exemplos:

\section{Eu nascendo pobre e feio \\ Ia ser triste o meu fim}

Mas crescendo, a bossa veio,

Deus teve pena de mim

("Riso de criança", 1930)

42 Angenor de Oliveira *11/10/1908 Rio de Janeiro, RJ + 30/11/1980 Rio de Janeiro, RJ Compositor. Cantor. Violonista. Apesar de ter recebido o nome de Agenor, foi registrado como Angenor. Mas esse fato ele só viria a descobrir muitos anos mais tarde, ao tratar dos papéis para seu casamento com D. Zica, nos anos de 1960. Ainda na infância, mudou-se com a família para o bairro das Laranjeiras, onde entrou em contato com os ranchos União da Aliança e Arrepiados. Neste último, tocava um cavaquinho que lhe fora dado pelo pai quando tinha somente 8 ou 9 anos de idade. Seu entusiasmo por esse rancho era tanto que, mais tarde, ao participar da fundação da Escola de Samba Estação Primeira de Mangueira, em abril de 1929, sugeriu que aquela agremiação tivesse as mesmas cores do rancho Arrepiados: verde e rosa. Desde então, essas duas cores passaram a formar um símbolo dos mais reverenciados no mundo do samba. - in http://www.dicionariompb.com.br/ acesso 22 de maio de 2011 
Quem é que já sofreu mais do que eu?

Quem é que já me viu chorar?

Sofrer foi o prazer que Deus me deu

Eu sei sofrer sem reclamar

(“Eu sei sofrer”, 1937; espécie de desabafo de Noel, doente, já próximo da morte)

A voz de confissão autobiográfica aqui se revela também com função de uma voz narrativa, constituindo um relato da realidade do compositor, e a frequência do uso do presente, da acentuação do singular na primeira pessoa e a co-relação com a sua biografia, ou ainda envolvendo suas reflexões políticas, filosóficas, amorosas com sabor de desilusão ou ainda relatando sofrimento e outros temas, não apresentam ambiguidade capazes de proporcionar dúvida de que ali há uma apresentação pessoal.

São mencionados como sambas autobiográficos por Castelar e Araújo (1999, p. 147), “Dama do cabaré"(1936) , "Pra que mentir" (1937), "Último desejo” (1937) "Filosofia” (c/ André Filho, 1933), “Malandro medroso"(1930), “Até amanhã” (1932), “Felicidade” (c/ René Bittecort, 1932), "O sol nasceu pra todos" (c/ Lamartine Babo, 1933), "Três apitos" (1933), "Prazer em conhecê-lo" (c/ Custódio Mesquita, 1932), “Cem mil réis” (c/ Vadico, 1936), “João Ninguém” (1935), “Leite com café” (c/ Hervé Cordovil, 1935), “Feitiço da Vila” (c/ Vadico, 1934), "Balão apagado" (c/ Marília Batista, 1936 -1961), “Tarzan, o filho do alfaiate” (C/ Vadico, 1936), “Ao meu amigo Edgar” (c/ João Nogueira, 1935 - 1938).

A composição autobiográfica de Noel é na verdade uma característica de destaque e um recurso produtivo para a elaboração de seus sambas. Noel Rosa fala daquilo que conhece : de sua vivência, de sua cidade, do samba, das mulheres com quem se relaciona ou seja, de sua própria vida, esse é o fato principal para fazer de Noel o "Poeta da Vila".

Conhecido no meio de outros compositores, na boêmia e na sociedade do Rio de Janeiro de seu tempo, ele é clássico e produzia um tipo de música que na época era popular, obtendo o resultado de uma musicalidade que pela proximidade desenvolvida por meio da linguagem e revelando-se de forma simples, expressando situações cotidianas, fala diretamente ao povo. 


\title{
2.1.2
}

A REPRESENTAÇão do FEMININO

\author{
"É na esquina da vida \\ Observo o valorizado \\ Que o homem dá à mulher e ao amor \\ E é por isso que ela \\ Em qualquer situação \\ Zomba da gente, sempre cheia de razão ${ }^{43}$,
}

Vasconcellos (2004) apresenta na biografia de Noel Rosa, uma vida amorosa movimentada e atribulada. Teve cinco amores destacáveis na sua biografia:

\begin{abstract}
A primeira, Clara, foi o amor dos tempos de escola, para quem compôs "Prazer em conhecê-lo". A segunda, Fina, foi o primeiro amor verdadeiro, para quem compôs "Três apitos" e "Seu riso de criança" . A terceira foi Julinha, que morava em um barracão muito modesto na Penha e pra quem Noel dedicou provavelmente "Meu barracão", em lembrança do local que dividiram por um tempo naqueles bairros. A quarta foi Lindaura, moça do bairro que ele conhecera quando criança, na escola da mãe, e que começou a cortejar bem mais tarde, em 1933. Foi com ela que Noel se casou, sob pressão das duas famílias (e da polícia, devido a uma denúncia de que raptara quando ainda era menor). O casamento correu no final de 1934, para que Noel pudesse levá-la consigo em 1935 para Belo Horizonte, quando tentaria melhorar sua saúde já precária. Ao voltar ao Rio, Lindaura ficou grávida, mas perdeu a criança ao cair da árvore no quintal de casa, em 1936. A quinta mulher - o maior amor da vida de Noel - foi Ceci, bailarina de cabaré da Lapa, que ele conheceu em Junho de 1934, e para quem compôs "A Dama do Cabaré" , "Ilustre Visita", "O maior castigo que te dou", "Pela décima vez" e "Último desejo". Depois que voltou de Belho Horizonte, onde viveu com Lindaura e com Ceci ao mesmo tempo, até que esta o largasse para viver com Mario Lago, causando muita tristeza a Noel. (Cf. Vasconcellos 2004, p.16)
\end{abstract}

Para o desenvolvimento da reflexão desse tema, chama-nos a atenção o que encontramos ao conferir as palavras de Ricardo Cravo Albin pela maneira que fez sua apresentação em reflexões sobre as composições de Noel. Albin, fazendo menção a pesquisa de João Máximo e

43 Esquina da vida Noel Rosa / Francisco Matoso 193478 RPM Mário Reis Columbia 22.242-B Cf. Fonte impressa: Máximo \& Didier 1990, p. 260 
Carlos Didier, apresenta as seguintes considerações: “... não poderia mesmo passar despercebido que a vida de Noel foi quase toda registrada em seus sambas.

Difícil é encontrar-se uma música que não tenha a veia específica. Suas inúmeras músicas que falam de amor comprovam que Noel foi apaixonado por muitas mulheres. A mais famosa delas Noel conheceu numa noite de São João, no Cabaré Apolo, da antiga Lapa, a bailarina Ceci, uma campista de 16 anos que o poeta amou até morrer. Para Ceci, Noel fez "Pra que Mentir", "O maior castigo que te dou”, "Dama de cabaré”, "Silêncio de um minuto", "lustre visita”. Ou ainda a marchina póstuma: "As pastorinhas."44

Vasconcellos (2004), conta 124 músicas da autoria de Noel Rosa, resultando o total de $66 \%$ de sua gravação referentes ao tema da mulher presente nas canções. Como fora dito anteriormente, a vida amorosa de Noel era agitada, não só elas foram fonte de inspiração para o compositor em questão, mas a figura feminina lhe suscitou várias personagens, resultando no que chamado por Vasconcellos (2004) chama de diferentes visões sobre a mulher.

Essas "visões" se compreendem entre a mulher e o humor, o tema da falsidade/ mentira; a mulher que se vai, a despedida, a ingrata; a traidora e outros temas. No que se refere às mulheres, o sambista é de acordo com a época, muitas vezes "machista" em alguns momentos, mas sem deixar de amá-las com intensidade. Suas canções de amor, são também permeadas de pessimismo e ironia, pontos que discutiremos na sequência desse tópico. Noel não desconsiderava a possibilidade da auto-ironia.

Cumpre ressaltar que não são frequentes as queixas de amor nas letras do poeta da Vila. Antiromântico, para não dizer descrente, senhor de si e de seus sentimentos e intenções, o pragmático Noel ganha do amor, mas o amor não ganha dele. É como se o sambista dissesse nas entrelinhas de suas letras: "O amor não é para ser levado a sério. Cada paixão esquecida é mais um samba que eu faço."

Entretanto, nas letras inspiradas em Ceci, uma paixão renitente e bem lembrada, a coisa muda de figura, e Noel revela uma outra fisionomia: apaixonada e ciumenta, e principalmente séria, muito séria. Trata-se de composições de tom sabidamente autobiográfico, todas na primeira pessoa, e nas quais o eu-poético nada tem de fictício. (Carvalho \& Araújo 2001, p. 54)

A respeito do sentimento de paixão, Noel compunha no sentido de fazer vir à tona todas essas dimensões do núcleo passional, a partir do contato do texto com a melodia adequada. É quando o compositor explora seus sentimentos mais íntimos, mesmo aqueles

$44 \quad$ Aalbin 1997, p.36 
inexplicáveis, e, no entanto, a melodia desce lá no fundo para "fisgar" a autenticidade da emoção, viabilizando a atuação persuasiva da música. É quando a emoção parece experiência vivida conforme afirma Tatit em seu $O$ século da canção (1995, p. 36).

Seus atentos biógrafos apontam em alguns textos, considerações afirmando o fato de Noel Rosa, em suas letras, nem idealiza nem mitifica o amor e a mulher ${ }^{45}$. A justificativa para esse fato é que, sua visão da vida e do amor, nada romântica nem idealizada, é o motivo que faz desacreditar que pudesse ser amado.

\begin{abstract}
"Sua visão de conjunto permite traçar uma espécie de teoria do amor em Noel Rosa, segundo a qual, se pode encontrar um posicionamento bastante crítico, para não dizer descrente do poeta da Vila, ora em relação à faculdade de amar, ora no que diz respeito ao objeto amor. Em outras palavras, Noel questiona a própria capacidade de amar e ser amado, do homem e da mulher. Os poucos textos que fogem a essa visão crítica constituem, como já referimos, exceções e, como tal, só fazem confirmar a regra geral acima enunciada." (Carvalho \& Araújo 1999,p. 19)
\end{abstract}

Uma breve apresentação das mulheres presentes em suas canções, são: a "Mulher indigesta”, e a mulher presente em "Gago apaixonado" sem citar nomes, as personagens geram de "estresse" aos que com elas se relacionam e toda a situação do relacionamento é apresentada na letra da canção em contexto de muito humor.

A criatividade de Noel, para falar da mulher que mente, lhe permitiu intitular uma canção de "Você só ... mente" , mais uma vez conferindo a dosagem do humor, sua brincadeira neste do título da canção explora a mentira da mulher tema também em “Mentiras de Mulher" e "Mentir" a mentira é destacada como inevitável para a vida em sociedade e uma virtude das mulheres.

Há quem garanta que o samba Mentir foi feito depois de ser apresentado a uma admiradora, numa festinha em casa de família. Conhecendo-o apenas de nome, a moça teria ficado desapontada. Esperava um compositor bonito como suas músicas. Deixou escapar um "oh"! , ao que Noel, sem perder o controle, indagou:

-Sente alguma coisa?

-Sim - respondeu a moça, um tanto embaraçada. - Um apontada aqui, mas já passou. (Máximo \& Didier 1990,p. 480)

Compõe ainda essa seleção de letras sobre mentiras, falsidade da mulher entre elas

45 Carvalho \& Araújo 1999,p. 19 
"Pra que mentir", fruto do seu desabafo sobre Ceci com Vadico ${ }^{46}$, base de diálogo, conforme interpretação de Rodrigues (2003), para a inspiração de Caetano Veloso compor "Dom de iludir" não só pelo estilo coloquial, mas pelos versos livres e metalinguagem, outra composição de mesmo tema é "Já sei que tens um novo amor", "Contraste" e "Ilustre visita" também dedicada a Ceci contendo declarações tão diretas como: não existe nessa vida pessoa mais fingida do que você.

A mulher que engana e trai tem sua representação em "Vai haver barulho no château”. O barulho no título representa o descontentamento pelo comportamento representado na canção; “Uma jura que fiz” em parceria com Ismael Silva. A desilusão o leva a fazer uma jura para não mais amar por afirmar que a mulher vive mudando de ideia. "Não foi por amor" , "Vingança de Malandro" e "Verdade Duvidosa" trazem nestes sambas, a mulher como aquela que é enganada.

É recorrente ainda o tema da confissão do amor à mulher. Assumir-se e declarar-se apaixonado ainda que com resistência a este sentimento, é um dado conferido em alguns dos sambas de Noel. O tema da confissão do sentimento do amor conferindo um tom de autobiografia em alguns momentos e em outros livre criação como em: "Pela primeira vez", "Pela décima vez”, e "Vejo amanhecer" "Três apitos", “Último desejo", "Provei” entre outras.

Sejam elas ficcionais ou não, revelam e encontram, estas e outras personagens um espaço no universo da criação do compositor.

\subsubsection{Noel e o Rio de Janeiro}

Noel de Medeiros Rosa nasceu em Vila Isabel, bairro do Rio de Janeiro, em 11 de Dezembro de 1910 e morreu na mesma cidade, na mesma casa, em 4 de Maio de 1937, com 26 anos de idade. O Rio era a cidade mais importante do Brasil, onde se concentravam o Senado e a Câmara dos Deputados, os órgãos públicos federais e seus funcionários, e onde era mais intensa a movimentação cultural e, especialmente, se referindo à música brasileira. A cidade, por sua importância, atraia uma enorme quantidade de pessoas de todas as partes do país, que vinham migrar ali ${ }^{47}$.

\footnotetext{
$46 \quad$ Máximo \& Didier 1990, p. 449
}

47 Vasconcellos, 2004 p. 13 e 14 
O samba sempre encontrou no Rio um lugar de destaque. Sendo sua terra natal, como cita Jacy Pacheco ${ }^{48}$ em seu breve comentário sobre a vida e os amores de Noel Rosa, foram de fato, as grandes faixas do compositor. Os registros de surgimento do início dos blocos e escolas carnavalescas de bairros, gerou o que se pode chamar de "geografia carioca do samba" título da obra de Luiz Fernando Viana e Bruno Veiga 2004 e claro, a Vila Isabel, não poderia deixar de encontrar um "espaço" entre tais páginas:

A modéstia nunca foi mesmo o forte dos moradores de Vila Isabel. Em seus versos, Noel traduziu o orgulho, a auto-estima do bairro, característica que ainda permanece, apesar de alguns sinais de deterioração física e social. Caminhar pela avenida 28 de setembro é constatar a força desse amor próprio, expresso em cartazes, letreiros e nas calçadas onde se pisa, as "calçadas musicais", pedras portuguesas formando notas e reverenciando a obra de Noel - que também esta sentado, em forma de estátua numa mesa posta no canteiro central do Boulevard.

No bairro também moram outros nomes da música popular brasileira, Francisco Alves, Lamartine Babo, Orestes Barbosa, Nássara, Christovam de Alencar, Evaldo Ruy, Valzinho, Ciro de Souza ... "Sem falar na proximidade que há entre Vila e Mangueira. O cantor Jamelão mora na Jorge Rudge ainda Vila, caminho para a Mangueira, rua que Carlos Cachaça, nos dias de feira aparecia para ver os amigos do bairro vizinho. A musicalidade de Vila Isabel não morreu no bojo do desaparecimento precoce de Noel, a 5 de maio de 1937. (Vianna 2004p. 91)

Fica então justificada a falta de modéstia dos moradores da Vila Isabel, tão famosa no samba, e ao mesmo tempo, tão querida devido aos "frutos" frondosos num verdadeiro berço do samba. Noel Rosa é o cantor da Vila Isabel, cantado em sambas não restringindo somente os famosos bairros do Rio de Janeiro, mas encontra lugar também em melodias em todo o Brasil $^{49}$, o destaque se dá em Noel de fato ser o grande compositor profundamente identificado com o espírito e o charme de Vila Isabel.

Esse bairro de classe média localizado a seis quilômetros do centro do Rio, na área

\footnotetext{
48 A vida e os amores de Noel Rosa, Jacy Pacheco 1976 Editora Cordel

${ }^{49}$ Essa é uma época que se encontram inúmeras as indicações de músicas que se referem positivamente ao Brasil como uma terra musical, como encontramos nas referências de "Aquarela do Brasil" (Aquarela do Brasil Ary Barroso 193978 RPM interpretada por Francisco Alves) já sugerindo a figuração do Brasil como "terra do samba e pandeiro", citando um samba de exaltação do país, encontramos no samba de Osvaldo Silva o samba "Azul e Branco" (Azul E Branco Osvaldo Silva / Benedito Lacerda 193378 RPM) . É interessante mencionar, gravado por Carmem Miranda o samba "Eu gosto da minha terra" assinado por Randoval Montenegro (Eu Gosto da Minha Terra Randoval Montenegro 193078 RPM). Entre todos, são as exaltações do samba feitas na "época de ouro da música popular" e Noel Rosa como um de seus mais geniais criadores. Cf. MORAES \& SALIBA 2010 , p. $306-307$ e 308
} 
oeste da cidade (perto de onde hoje fica o Maracanã). A Vila Isabel, em relação há determinados locais citados por Noel em suas letras aparece próxima: o Centro $(6 \mathrm{~km})$, a Lapa $(5 \mathrm{~km})$, a Mangueira $(1 \mathrm{~km})$, o Salgueiro $(3 \mathrm{~km})$, a Penha $(10 \mathrm{~km})$. Na rua principal do bairro Bolevard 7 de Setembro - , a uma quadra da rua onde morava Noel (Theodoro da Silva), havia uma linha de bonde com ligação com todos estes locais citados, o que facilitava os deslocamentos ${ }^{50}$.

Ainda no que diz respeito ao lado nacionalista da obra de Noel, merece destaque o amor aos bairros que lhe consagraram um poeta-compositor, a exaltação da cidade do Rio de Janeiro e seus bairros e subúrbios, principalmente a sua querida Vila Isabel, referência importante em quatro sambas: "Eu vou pra Vila” (1930), “Bom elemento” (c/ E. Silveira, 1930), "Palpite infeliz" (1935) e o eterno "Feitiço da Vila" (c/ Vadico, 1934), em Noel revela consciência do papel reservado ao Rio de Janeiro como grande centro elaborador e irradiador da cultura nacional, conforme sugerem os versos do samba:

\section{Lá em Vila Isabel}

Quem é bacharel

Não tem medo de bamba

São Paulo dá café

Minas dá leite

E a Vila Isabel da samba ${ }^{51}$

Noel expressa muito carinho por alguns bairros na composição em "Palpite infeliz" (1935), não somente falando da Vila Isabel, o compositor cita ainda outros bairros manifestando também um carinho pela cidade, conhecer lugares e vale destacar que ao falar da questão do samba nesse verso, não são bairros nobres, é a periferia da cidade, o reduto, o lugar que o malandro tem na cidade e onde ele se encontra. Nesse verso, aproveita ainda para homenagear vários outros bairros além da vila:

\footnotetext{
50 VasconcellosS, 2004 p. 13 e 14

* Não é contabilizado pelo autor a kilometragem, mas aparecem também em suas letras bairros distantes da Vila Isabel como a Pavuna.

51 Carvalho \& Araújo, 1999 p. 128
} 


\section{Salve Estácio, Salgueiro, Mangueira, \\ Oswaldo Cruz e Matriz}

Que sempre souberam muito bem

Que a Vila não quer abafar ninguém

Só quer mostrar que faz samba também

Observando a apresentação de Vasconcellos (2004) são registrados 23 bairros em suas músicas. Os mais citados são a Penha (6 músicas) e a Vila Isabel - onde ele nasceu e viveu (4 músicas). As citações sobre a Vila decorrem do orgulho que Noel sentia do seu bairro ${ }^{52}$.

Noel se sente na essência carioca e sabe que é introduzido ali por meio do samba, cobiça o dom de se comunicar e se aproximar do o povo. Sua geografia e seu meio para conhecer, amar e descobrir sua cidade, se sintetizam no samba, esse é literalmente o caminho percorrido por ele "indo pra Vila" e o que lhe permitiu entrar no coração do povo:

\footnotetext{
“Às vezes, eu vinha para casa, alta hora da noite. Nem viva alma. Só a emoção das estrelas no alto. De repente, lá numa esquina qualquer, desembocava um vulto. Assoviava. Era "Eu vou pra Vila". Eu me sentia feliz. Tinha entrado no coração da cidade; compreendia a sensibilidade carioca; sabia comunicar-me com o povo." (Máximo 1990, p. 141)
}

Sua sensibilidade lhe permite descobrir e abraçar o mundo contido dentro da Vila Isabel: suas figuras, seus personagens que retratam e representam toda a cidade do Rio de Janeiro. É partindo desse espaço que ele construiria um novo, no qual as formas se aproximariam do real mas seriam, de algum modo, mais fluidas. O malandro das ruas seria transformado por Noel em símbolo. É o "feitiço" da Vila incorporado a magia dos olhos de artista descobrindo o cotidiano, encontrando ironias, as anedotas, as brincadeiras, os amores e as desilusões de todo dia.

\subsubsection{Noel e a sátira social}

Noel nasceu no ano de 1910, no momento, na noite da Revolta da Chibata, fato que seus pais acreditaram ter ligação com as dificuldades do seu parto difícil e com seu problema no queixo. ${ }^{53}$ Posterior a essa manifestação, deu início a Primeira Guerra Mundial (1914 -

52 Vasconcellos 2004, p. 70

53 Seus biógrafos ao registrar o fato relatam: "O menino nasce nesta manhã de domingo, 11 de dezembro de 
1918), já a década de 1920, Baer (2002, p. 51) atesta ter sido uma época de dinamismo da economia brasileira, destaca o café com crescimento de 56\% na exportação em 1919.

O final da década de 20 e o início da década de 1930 foi um período marcado pela Revolução, para muitos historiadores, pode ser explicada como o movimento mais importante da história do Brasil do século XX, levando ao fim à Primeira República. Para o historiador Fausto, (1972), foi ela quem, acabou com a "hegemonia da burguesia do café, desenlace inscrito na própria forma de inserção do Brasil, no sistema capitalista internacional"1.

O quadro nacional comporta ainda questões de crescimento da indústria, a política de grandes estados, assim denominada por Srour (1987,p. 241) ou popularmente conhecida como “política do café com leite", manifestação da hegemonia São Paulo e Minas Gerais.

Com a crise mundial do capitalismo em 1929, a economia cafeeira não conseguiu manter-se. O Presidente Washington Luís (1926- 1930), tentou conter a crise no Brasil, mas em vão. A partir de 1930, a sociedade brasileira viveu importantes mudanças. Acelerou-se o processo de urbanização e a burguesia começa a participar cada vez mais na vida política. Com o progresso da industrialização, a classe operária cresceu muito. Vargas, adotando uma política de governo dirigida aos trabalhadores urbanos, tentou atrair o apoio dessa classe que era fundamental para a economia, pois tinha em mãos o novo motor do Brasil: a indústria.

Nascido com o dom de compor tanto melodia como letra, Noel, tinha imensa facilidade para transformar em música e letra suas emoções e seus julgamentos, suas reflexões sobre a sociedade carioca dos anos 20 e 30. Suas letras revelam uma representação do humor , mas também registram o humor seco e sarcástico, como comentaremos posteriormente, Noel é um analisador de sua época.

Em suas letras, são apresentadas denúncias compostas com as mazelas nacionais, uma postura que revela a preocupação com o país e muitos vão chamá-lo por tal fato de nacionalista. Comprova-se a postura citada no samba "Onde está a honestidade?"54. A apresentação de um discurso contra a um oportunismo político referente ao governo da 1910. A cidade já está calma, a revolta dos marinheiros sufocada, o azul substituindo as nuvens de fumaça que ontem obscureciam o céu. (...) Por muito tempo, aliás haverá quem associe as dificuldades do parto ao clima de guerra que inquieta a população. Um parto tão difícil que o médico chamou outro para ajudá-lo, este se decidindo pelo emprego do fórceps. Um menino extraído a ferro, penosamente. Tudo muito complicado, sofrido, longas horas de espera madrugada a dentro. Máximo \& Didier 1990, p.19

(...) Algumas pessoas da família acharão que foi um erro seu não ter notado, senão meses mais tarde, que o menino nasceu com um problema no maxilar inferior, o fórceps usado pelo outro médico pegando-o de mau jeito, fraturando-lhe o osso num ponto vital, deformando-o para sempre. Martha e Neca, contudo, têm grande carinho por Graça Mello, jamais o culparão de coisa alguma. Quem sabe não foi mesmo o canhoeiro? Máximo \& Didier 1990, p.26

54 Noel Rosa 193378 RPM interpretado por Noel Rosa (1930) Parlophon 13.245-a - Fonte impressa Araujo1999, p. 130 
época, e também aos revolucionários de 1930, recém-chegados ao poder. Se faz perceber nos versos:

Você tem palacete reluzente

Tem jóias e criados à vontade

Sem ter nenhuma herança nem parente

Só anda de automóvel na cidade...

E o povo já pergunta com maldade:

"Onde está a honestidade?"

As críticas aos privilégios sociais, de forma clara e destacada, aparecem em muitos outros versos como em: Quem faz seus versos/ E no morro faz visagem / Leva sempre desvantagem / Dorme sempre no distrito / Entretanto quem é rico / E faz samba na avenida / Quando abusa da bebida / Todo mundo acha bonito, na letra da canção "Se a sorte me ajudar". ${ }^{55}$

Fatos muito interessantes são citados por Vasconcellos (2004) como os problemas vividos por Noel na infância mediante as dificuldades financeiras do pai - figura que ele associou à honestidade exagerada - e a convivência constante com os problemas de dívida e de falta de dinheiro enfrentados pela família.

Posterior a esse fato, a sua carreira de compositor, não lhe deixou em condição confortável. Acredita-se que o fato da necessidade de coisas materiais tenha se refletido na grande quantidade de músicas que fez falando do dinheiro (ou de sua falta) e em letras ou versos criticando a falta de honestidade no país $^{56}$ e na sua amizade e identificação com o malandro, que não se preocupava exageradamente com o trabalho desgastante e excessivo.

Noel Rosa era um jovem fascinado pela malandragem. Convivia com malandros, era parceiro de vários, fez sambas enaltecendo-os. Ou entendendo sua resistência ao batente...

Enquanto existir o samba Não quero mais trabalhar A comida vem do céu Jesus Cristo manda dar

...ou lamentando não ser um deles...

Tu podes guardar o que eu te digo

55 Se A Sorte Me Ajudar Noel Rosa / Germano Augusto 193478 RPM Aurora Miranda / João Petra de Barros (1934) Odeon 11.130-a Fonte impressa: Araujo1999, p. 131

56 Vasconcellos 2004, p. 18 
Contando com a gratidão

E com o braço habilidoso

De um malandro que é medroso

Mas que tem bom coração

... ou ainda lhes reconhecendo a esperteza:

Muito mais que a canoa

O malandro em terra joga

A canoa afunda à toa

Ele vira e não se afoga

(Máximo 2010, p. 59)

Talvez suas próprias dificuldades tenham sido um fator determinante para atentar-se ainda mais para os problemas sociais vividos pelos mais carentes representados em sua música.

Carvalho \& Araújo (1999) encontram no compositor um outro postulado modernista: a consciência crítica da realidade. Os autores afirmam que embora não fosse um panfletário (não era seu estilo e, além disso, havia a censura) algumas de suas letras apresentam, ainda que sutilmente, um tom de denúncia e de inconformismo. Outras, por meio do humor e da sátira,parecem em conformidade com o sentido geral de sua obra, marcada toda ela, sobretudo, pelo anticonvencionalismo e pela irreverência, justamente os dois signos mais fortes do Modernismo. Não só questões sobre modernismo, modernidade estão presentes em suas canções. Ele tem visão da situação exata ao comentar o subdesenvolvimento no quadro de 1930, com a letra originalíssima e tipicamente brasileira chamada "São coisas nossas":

Baleiro, jornaleiro,

Motorneiro, condutor e passageiro,

Prestamista e vigarista,

E o bonde, que parece uma carroça,

Coisa nossa, muito nossa ${ }^{57}$

É bem verdade que a magia do samba é destacada como essência da brasilidade. Conforme Fenerick (2005, p. 254), o brasileiro possui apreciação a arte de fazer o samba se torna-o um feitiço, destacando sua beleza. Dessa forma, uma apresentação musical fora do Brasil, o samba tocado por estrangeiros, fica descompassado e sem valor. O autor apresenta por exemplo a letra do samba "Samba da minha terra": Sou brasileira, tenho feitiço / Gosto do samba, nasci para isso / O fox-trot não se compara / Com nosso samba que é coisa rara / Eu sei dizer com ninguém / Toda beleza que o samba tem / Sou brasileira, vivo feliz / Gosto

57 Fonte impressa: Carvalho \& Araújo1999, p. 130,131 
das coisas do meu país.

De fato, o país vive um momento de exaltação à pátria, a valorização do nacional não é uma ideia única e inovadora de Noel Rosa, não há como negar seu amor pelo Brasil e pela cidade. Esse cenário the propícia inspiração para criar sobre sua capacidade de observação tanto do que é desajustado, no cenário nacional, quanto a beleza e alegria do país. São muitos os exemplos de sua irreverência e atenção a esse quadro, sem deixar de compor letras de relevância no que se refere ao amor pelo país, aparecem letras onde a situação real do contexto político da época é descrito, um exemplo é:

Quem dá mais

Por um violão que toca em falsete

Que só não tem braço, fundo e cavalete

Pertenceu a Dom Pedro, morou no palácio,

Foi posto no prego por José Bonifácio...

(“Quem dá mais?", 1930; e as riquezas do Brasil continuam "no prego", postas hoje por outros "patriarcas") 58

Segundo Avritzer (2008,p. 314) o debate sobre a corrupção se intensificou mediante a letra apresentada por Noel. Acredita-se ser a primeira vez exposta a ideia da apresentação do que chama de "falta imperdoável à pátria". Avritzer comenta ainda da apresentação da canção em blocos constituídos de um eixo central: a corrupção. É uma narração satírica de um leilão do Brasil:

\begin{abstract}
O jogo da canção combina a brutalidade original de um passado escravocrata que se concentra na raiz da identidade brasileira com o subtrato musical do blues e na longa tradição musical de origem africana o blues é tanto um estado de espírito quanto a expressão do sentimento geralmente de tristeza e depressão. Nesse Brasil em que foi tudo colocado à venda tudo pode ser negociado, tudo depende sobretudo do quando nos disponhamos a pagar a pratica da corrupção esta muito distante a se reduzir à apropriação particular da coisa pública ou ao comportamento desviante de indivíduos.

(...) Como se vê, ao menos no argumento do compositor popular há sempre suspeita prévia de que é difícil desgrudar a corrupção desse enredo problemático em que se constrói a aventura nacional brasileira. (Avritzer 2008, p.317)
\end{abstract}

A força de conscientização política é um utensílio do qual Noel se aproveita e sabe

58 Fonte impressa: Caravalho \& Araújo1999, p. 130 
manejar, Araújo constatam em vários trechos de suas canções: crítica à burocracia da época "Espere mais um ano" Espera mais um ano que eu vou ver/ Vou ver o que posso fazer/ Não posso resolver neste momento / Pois não achei o teu requerimento ${ }^{59}$.

As composições aqui citadas, e outras como: "Com que roupa?", "Prazer em conhecêlo" "Mentir", "Não tem tradução", “Onde está a honestidade?" são as que mostram um perfil da sociedade burguesa da época e apresentam a capacidade de reflexão do compositor ante aos problemas sociais do impacto da modernidade.

Segundo o historiador e pesquisador de música popular brasileira, Renato Vivacqua ${ }^{60}$, os políticos brasileiros sempre serviram de inspiração aos compositores populares. Alguns, como Getúlio Vargas, consagraram este estilo transformando-se em alvo de marchinhas picantes. Outros, sabendo da predileção que a música tem que o povo tem pela música, chegaram a fazer encomendas pessoais. Tudo na surdina. (...) A MPB vem fazendo até hoje eco às versões do poder, com raras exceções.

Nesta sociedade sem referência de verdadeira identidade burguesa, isto é, sem os moldes europeus, pode-se dizer que essa classe média só vai adquirir identidade com a futilidade proporcionada pela mídia impressa, radiofonizada e depois televisiva das décadas de 50 e 60.

\subsubsection{O filósofo do samba}

Mariz (1996, p. 125) afirma Noel ter granjeado tal epíteto, devido a sua originalidade e particularidade de seus sambas, ou, conforme ele mesmo atesta, tal apelido se adequa pela estranha personalidade de seus versos.

Chamado de "filósofo do samba", apelido cunhado por Custódio Mesquita ${ }^{61}$, e apesentado assim em 1934 conforme conta Almirante ${ }^{62}$, conhecido assim popularmente, não sendo difícil compreender o motivo conferido a densidade de suas letras; não só de teor social, por suas reflexões sobre a sociedade, mas também pelas reflexões apresentadas sobre o amor, a vida, as mulheres enfim, pela sua originalidade de fazer samba.

No item anterior, o foco da visão criteriosa de Noel sobre a sociedade, percebe-se por

\footnotetext{
59 Espera Mais Um Ano Noel Rosa Noel Rosa c/ Artur Costa, 1932: LP/CD Noel Rosa: Inédito e Desconhecido Eldorado 79.83.0408 - 1983

60 Escritor, historiador e pesquisador de música popular brasileira.

61 Dantas 2003,p.25

62 Noel é apresentado a plateia com a alcunha de Filósofo do samba. Cf. Almirante,1977,p.119 e 190
} 
sua reflexão sua posição sobre os diversos questionamentos do povo no referente à temática social e sobre o cotidiano; e muitas vezes sobre si mesmo, sobre a sua vida, a vida em si, sobre vida e morte como se nota nas suas letras.

"Filósofo cantor da cidade ${ }^{63}$ " ou "filósofo do samba" são epítetos pelos quais se tornou popularmente conhecido. Conforme o teor encontrado em suas letras, identifica-se interesse e capacidade em expressar-se, é dessa forma que fez amizades e por meio troca de experiências, se enriqueceu de diversas inspirações, muitas reflexões, aprendendo a valorizar e conhecer outros lugares, ritmos e melodias fator proveniente de sua mistura de asfalto e morro conforme comprovamos na canção "Feitio de Oração" (integrante do corpus).

O sambista ainda não havia despertado nele. Era apenas o executor do violão e autor das primeiras emboladas e canções. Era já o filósofo autentico, que dava graças a Deus por ser pobre de bolso e rico de inspiração.(Pacheco 1958,p.60)

Suas letras são pistas por intermédio das quais os pesquisadores de sua obra inferem e tentam desvendar considerações pessoais e reflexões a respeito da sua visão sobre a vida, a época, o mundo sobre sociedade e o amor. Não raro essas pistas se misturaram com referências autobiográficas, não só conferidas em seus estudos biográficos, mas em suas próprias letras comentando sobre o título a ele conferido diz: Eu tenho fama de filósofo amador $^{64}$ Vários exemplos podem ser constatados por exemplo na letra de "Feitio de Oração" presente nas admoestações incorporadas na canção no verso: Quem acha vive se perdendo ${ }^{65}$ ou ainda nas imagens apresentadas na canção intitulada "Mão no remo" e "Silêncio de um minuto" onde a reflexão sobre a vida e sobre o amor.

Às reflexões noelinas, em âmbito social, não afirmam o dinheiro pelo valor em si, envolvem algo maior que o valor material: o caráter de personalidade, de quem o possui. Muitas vezes ao se referir a uma musa inspiradora, fixa a ideia da questões do amor e não nas questões da mulher. É se aproximando do sentido lato da palavra "filosofia" o espaço onde se aprofunda a discussão do sentido / valor das coisas, como por exemplo em: Quanto a você da aristocracia / Que tem dinheiro, mas não tem alegria / Há de viver eternamente sendo escrava dessa gente / Que cultiva a hipocrisia.

Rocha (2002), ressalva a importância desse samba ainda para outro compositor:

63 Cf. Moraes \& Saliba 2010, p. 308

64 Com mulher não quero mais nada, Noel Rosa / Silvio Pinto 1983 Noel Rosa Inédito e Desconhecido LP/CD Coisas Nossas

65 Feitio de oração", c/ Vadico, 1933 
Adoniran Barbosa:

\begin{abstract}
"Filosofia" sinaliza um momento importante na carreira de Adoniran. Em 1933, depois de muita insistência, ele consegue não ser "gongado" no programa de calouros da Rádio Cruzeiro do Sul, cantando "Filosofia". Adoniran iniciou sua carreira no rádio através desse samba de Noel. O "manifesto do sambista", aí representado, bem exemplifica a trajetória do compositor de Trem das Onze. Adoniran viveu "escravo dos seus sambas". E , em 1982, quando a imprensa noticiou a sua morte, ele havia cumprido um destino semelhante ao da maioria dos sambistas de sua geração: morreu pobre. (Rocha 2002, p.112)
\end{abstract}

A vida de Noel é lembrada por momentos vividos na boêmia, na companhia dos amigo, sempre alegre, relacionando-se com várias mulheres, porém, sua biografia aponta para suicídios da avó e de seu pai, e sua mãe tem consigo desconfiança de que ele tentará suicídio $^{66}$. A vida lhe era cara, ele gostava da vida. E a dor da morte deixa uma marca, porém lhe rende uma bonita composição refletindo também a questão de o que é visão da sociedade e sobre a distinção de sentimento de natureza pessoal com o falecimento de seu pai em "Silêncio de um minuto" ao dizer: Luto preto é vaidade / E saudade não tem cor.

Essa questão é ainda envolta sobre as considerações influenciadas pelo samba. O samba que é um fator representante de uma filosofia própria: a adequação as figuras do malandro, o contexto social do samba e seus redutos, ambos ligados à periferia, marginalizada e discriminada na época. Em suas composições há respostas e perguntas para a sociedade, questionamentos de culturas, valores da elite, juntamente com observações constituindo fato desabafo. São o fruto de reflexões nas quais muitas vezes frisam-se e cotidiano e sua própria vida. O compositor parece apresentá-la como base e fruto de muitas de suas reflexões. Aprendendo e ensinando sobre a ela e o mundo. Noel não "esconde" a vertente filosófica que possuía.

Neto (1998,p. 140) afirma o fato de Noel ter delineado uma filosofia de vida por intermédio da música popular, provindo daí o fato de ser denominado Filósofo do samba.

São vários os sambas de abordagem dessa perspectiva compostos por Noel e com seus parceiros, citados por Carvalho \& Araújo (1999, p. 145) a saber: "Não faz, amor" (c/ Cartola, 1932), "Rir" (c/ Cartola e Francisco Alves, 1932), "Vitória” (c/ Romualdo Peixoto, 1932), "Esquina da vida” (c/ F. Mattoso, 1933), “Até amanhã” (1932), "Remorso” (1934), “Vejo amanhecer” (1933), “João Ninguém” (1935). O autor não fala de uma filosofia

66 Certa manhã, ouvem -se gritos, correria, confusão no fundo do quintal Noel acaba de rolar do alto do barranco, fere braços e pernas, parece muito machucado. Deve ter pisado em falso na terra úmida, escorregado e caído. Portanto, um acidente. Mas Martha, mortificada, teme que não. Em sua cabeça - muito sugestionada pela tragédia que se abateu sobre a família neste mesmo quintal - ficará a certeza de que o filho, inconformado com o fracasso nos exames, quis se matar. Cf. Máximo e Didier 1990, p. 79 
idealizada e abstrata, Noel parte de algo que conhece, tendo autoridade para falar de si próprio, de seus questionamentos. Usa o caráter filosófico que encontra no samba e se torna um destaque e referência com seus sambas em primeira pessoa. ${ }^{67}$

\subsubsection{O espaço da comicidade na obra de Noel Rosa}

Mulher indigesta, Coisas nossas, um dos traços marcantes de Noel Rosa é o tratamento que ele destinava à corrupção e a pobreza no Brasil. Suas músicas têm uma atualidade assustadora, levando-se em conta que elas foram elaboradas nas primeiras décadas do século passado. Muitas vezes faz comentários com uma ironia ferina no tratamento de diversos assuntos.

Um dos traços marcantes do estilo de Noel é o humor. O filósofo do samba gostava de rir da sociedade em suas letras. Com ironia e malícia, satirizava fatos, pessoas e instituições, no melhor espírito da máxima latina Ridendo castigat mores (rindo castiga os costumes). Nas letras de fundo amoroso, ria-se também do amor, como que numa adaptação zombeteira da referida máxima, reescrita a seu modo: Ridendo castigat amores. Amores que, no seu caso, não foram poucos. (Carvalho \& Araújo 2001, p. 54)

Dantas (1988,p.113) sobre seu espírito satírico, irônico, mordaz, coloca-o como um observador de seu tempo. Refere-se aos seus sambas, terem atuado como uma espécie de fotógrafo-poético-musical, retratando o humor e ironia, tipos, lugares, ambientes, coisas, situações, tudo isso visto sob sua ótica boêmia, com seu jeito peculiar de dizer e compor. Dessa forma, fazendo a paródia e a sátira, veículos de crítica e suas grandes armas.

O humor tem um espaço de grande presença em todo o conjunto de composições de Noel Rosa. Destacado como um ponto forte aparece relacionado ao amor, a crítica, na sua expressão autobiográfica rindo de si mesmo e do cotidiano. Há os que atestam encontrar presente em Noel Rosa a mistura de poesia e humor ${ }^{68}$ :estes são de fato os elementos que ele usa para compor toda sua obra.

\footnotetext{
67 Há comentários mais detalhados amente sobre o legado que deixou entre de seus sambas e quase sempre na $1^{\text {a }}$ pessoa ao citar outras informações sobre seus sambas autobiográficos ao longo do trabalho com destaque na discussão apresentada sobre "Noel por ele mesmo".

68 Procedimento irreverente que mistura poesia e humor. Nos primeiros modernistas, tinha a finalidade de chocar de agredir o convencionalismo acadêmico. Em Noel, cuja obra satírica pode ser considerada como um grande poema - piada, o objetivo não chega a ser propriamente o de chocar, mas antes o de fazer blague, com muito humor e ironia. cf. Carvalho \& Araujo 1999, 137,138
} 
Para além da crítica social, a obra de Noel está cheia de signos pessimistas. Mesmos nas canções compostas com certo humor, percebe-se o crescente uso de temas como tristeza, pobreza, felicidade, infelicidade, saúde, paixão, etc. O defeito físico de Noel - o queixo afundado - ficava mais notável com a fase adulta e, por isso, evitava grandes reuniões sociais. Entretanto, ele tornava-se cada vez mais conhecido pelas suas músicas. Aos 22 anos já era uma figura pública. (...)buscava nos bares, botequins e cabarés, cada vez mais, seu refúgio. (Monteiro, 2001)

Na opinião de João Máximo e Carlos Didier69 ${ }^{69}$ a primavera de 1934 talvez tenha sido o último capítulo feliz da vida de Noel Rosa e o motivo que se alega é sua paixão por Ceci, consagrada em sua obra como : a dama do cabaré... Esse fato, seja coincidência ou não, influenciou em sua produção e período de farta produção. De um lado, o humor sobre a sua situação, de outro a crítica à sociedade de então, notadamente aos espertos, que filavam cigarros, almoçavam de graça, viviam de carona e de quebra emprestavam dinheiro e não pagavam...

Da "cidade maravilhosa" registra-se que era uma capital de muitas festas. Festas e feriados anuais, fossem ou não religiosos, envolviam de alguma maneira ou contavam de certa forma com a participação dos compositores de música popular, exemplos disso são: o Carnaval, a folia de reis, as noites de junho, a festa da Penha em outubro.

Recordando a figura da pessoa do próprio Noel Rosa, nós o encontramos na boêmia, gostava de comemorações, e como uma coisa esta intimamente ligada a outra; os amigos, a alegria da festa confraternização com todos através de um brinde, ou seja: beber. São palavras do poeta da vila sobre a cerveja: "Loura como as louras espigas de milho, falsa como as falsas mulheres... Eu bato com ela no bucho, ela bate comigo no chão". ${ }^{70}$

Tomo vinho, tomo leite,

Tomo a grana da mulher,

Tomo bonde, e automóvel,

\section{Só não tomo Itararé ${ }^{71}$}

Não só a alegria e o bom humor compreendem a tópica do humor em Noel, há em sua obra um destaque realçando um "tipo" de humor que revela ironia um tanto cruel, satírico. Carvalho \& Araújo referem-se a apresentam Noel Rosa como aquele que usou e abusou do humor e à semelhança dos modernistas, lançou mão da paródia, da sátira, do poema - piada,

\footnotetext{
${ }^{69}$ Autores da série: Noel Rosa, as histórias e os sons de uma época

70 Cf. Noel Rosa, uma biografia - João Máximo \& Carlos Didier, 1990

71 cf. "Escola de malandro" , c/ O Machado e Ismael Silva, 1932: ref. A Itararé, a batalha que não houve na Revolução de 30; v. Máximo \& Dideier, p. 276
} 
do nonsense $^{72}$, do duplo sentido.

Os autores apresentam um foco de passagens de uma trinca de paródias em que o poeta da Vila brinca com a morte.

\section{Ensinei meu cachorrinho}

A passar sem ver comida:

Quando estava acostumado,

Ele disse adeus à vida. ${ }^{73}$

\subsubsection{A crônica musical}

Haussen (2001,p. 67) vê na expressão "Coisas nossas" de Noel Rosa o culto do momento, assim como as manifestações folclóricas, identificadas por Mário de Andrade como a própria cultura popular. ${ }^{74}$

Noel foi um homem daqueles que se encanta, desses que param e ficam atentos à observação e se aproximam da magia do que é considerado simples, do assemelhado ao, e tudo que lhe sirva de inspiração. O tempo, a vida, o samba e o morro, uniram dois grandes sambistas: Cartola e Noel Rosa. Essa amizade fenomenal frutificou e Noel subia o morro quase diariamente e passava horas ao lado do amigo. Com essa experiência ele adquiriu a poesia do morro, que fala do cotidiano. Cartola adquiriu a sofisticação e enriqueceu as palavras e expressões que utilizava em suas letras. Tal amizade frutificou o samba e a música. Levou a poesia cotidiana e seu valor para seus amigos intelectuais, que apreciaram e passaram a valorizar mais aquela forma de canção. No que se refere a Cartola, este tinha não só dom, mas também experiência de vida no morro, experiência para guiar o leme da música

\footnotetext{
72 Um dos recursos usados pela poesia modernista foi a da imagem ilógica, absurda, na linha do nonsense (ausência de sentido) surrealista. Em Noel, esse recurso está a serviço do humor, da irreverência e da ironia. Algumas pérolas do nonsense produzidas pelo poeta da Vila são de fazer inveja a muito modernista. Por exemplo: Quem dá mais? / Por um violão que toca em falsete / Que só não tem braço, fundo e cavalete ("Quem dá mais?", 1930) Quero que o sol / Não invada o meu caixão / Para a minha pobre alma / Não morrer de insolação ("Fita amarela", 1932) Ser palpiteiro neste mundo é tua sina / Vendeste o carro pra comprar a gasolina ("Palpite", c/ Eduardo Souto, 1932) Mais exemplos : Estátua da paciência (c/ J. Cabral, 1931) "Sem tostão" (c/ A . Costa, 1932), "Prato fundo" (c/ João de Barro, 19333), "Marcha da prima... Vera" (1934), "Precaução inútil” (1935), "Que a terra se abra" (1935), "De babado” (c/ João Mina, 1936), “Que baixo!” (c/ Nássara, 1936), “A. B. SURDO” (c/ Lamartine Babo, 1930) Cf.: Carvalho \& Araujo, p. 130 e 140

73 “Sem Tostão” Noel Rosa / Artur Costa 193278 RPM

${ }^{74}$ De fato, Mário de Andrade propôs e experimentou o encontro com a cultura popular de modo fortemente ambivalente. Numa variação do evolucionismo, a cultura popular apresenta-se em sua obra como valorização do primitivo, num confronto entre identidade e alteridade por meio de grupos humanos distintos. Acrescenta-se ainda, bem ao gosto romântico, a idéia de que a força nutriz da originalidade cultural brasileira está nas criações artísticas populares (Cavalcanti et al., 1992).
} 
popular brasileira e, sem dúvida, se tornou uma das maiores expressões artísticas do Brasil.

Leitão (2009, p.110) retrata o interessante trabalho de Noel a crônica e a poesia ocupam posição bem distintas. Ambas, porém, nos revelam desde logo as preservações do eterno da linguagem humana.

Dantas (1988,p. 113) o vê no bar, na rua , nas serestas, esquina, festas, com sua vocação de observador e crítico, muitas vezes provoca dor. A relevância abribuída pelo compositor ao cotidiano se destaca pelo valor que ele dá a vida, possui um desejo de viver e não se preocupa muito com o amanhã, fator facilmente constatado a sua pouca dedicaçao para evitar a boêmia quando se encontra com estado de saúde agravado em grau avançado de sua tuberculose. Valoriza a cidade do Rio de Janeiro, a beleza da mulher, do morro, das situações que o cercavam.

Os seus sambas registram seu tempo e são verdadeiras crônicas. Alguns retratam um olhar presente e atento a sua época e contexto social. Cotidiano, humor e criatividade, esta é a receita até mesmo para sua sobrevivência: afinal de contas, em meio às sucessivas crises do capitalismo periférico tupiniquim, que o brasileiro mais humilde ignora essa terrivel verdade de que "o dinheiro não é fácil de ganhar"?(Leitão, 2009p.141)

Muitas questões de cotidiano se incorporam em suas letras representando questões do povo, da sua atualidade e claro sem esquecer de seu nacionalismo, da sua importância para a valorização de algo tão popular quanto o samba. Seu destaque na música popular brasileira se fundamenta também na sua visão e consciência crítica e nesse espaço, enfatiza também problemas e questões do povo.

Nas suas "crônicas musicais", por exemplo, comparecem os personagens comuns da vida brasileira, os objetos e coisas que compõem a realidade moderna, os novos costumes e moralidade; enfim, a vida moderna com suas máquinas, tecnologia, espaço público e sua velocidade. Mas as suas composições não perderam o lirismo, a musa e o ser humano e suas questões vitais que se manifestam através de uma repetição constante.

\section{2 "É brasileiro já passou de português"}


“O samba é a voz do povo. Sem gramática, sem artificio, sem preconceito, sem mentira. É malicioso e ... ingênuo. O povo carioca sente a alma do samba." (Noel Rosa) ${ }^{75}$

Severiano (2008, p. 136) distingue Noel dos letristas de seu tempo (abre exceção de Lamartine Babo) com destaque a frequente utilização de rimas ricas, extravagantes, inesperadas, como as que misturam palavras portuguesas e estrangeiras citando como exemplo o samba "Dama do Cabaré”: você - soirré. Define todas essas características desenvolvidas num estilo enxuto, realista, de grande poder de síntese, que valoriza a língua do povo e desperta exageros românticos, jamais mitificando o amor ou a mulher.

São atribuídos a Noel Rosa vários destaques, uns fazem destacar o humor, assegurando que de tudo, Noel, ou ironiza ou faz humor, de alguma maneira suscita um motivo para o riso. Outros destacam-no como "Poeta da Cidade", ou ainda "Poeta da Vila" por sua maneira de "cantar" a cidade e sua amada Vila Isabel de modo sem igual; encontra-se em Noel a postura de pensador e filósofo no sentido de questionador social e político de sua época, os costumes, a vida. Mas há um foco de convergência por meio do qual se conhece Noel partindo de qualquer uma das citadas vertentes, e esse caminho é a linguagem de usada por Noel Rosa.

\footnotetext{
"foi um poeta popular de versos livres, cujas rimas se enquadravam dentro do ritmo dos acordes, arpejos e tons do seu violão querido". (...) É muito grande, muito grande mesmo, este pequeno Noel! ( Pacheco 1958, 31)
}

O poeta da Vila apresenta sua poesia como um transbordamento do cotidiano: no apito da fábrica, na conversa em um botequim, numa reflexão sobre a política da época entre rimas e justaposições inusitadas, nos provérbios deformados, na conversa com o positivismo e a filosofia popular.

Como afirmam Carvalho e Araújo (2001) o compositor apresenta letras que falam por si mesmas, em estilo direto e, em certos casos, até agressivo,em sua obra, há um conjunto identificado entre poesia e melodia elementos quase absolutos nas composições. As palavras, na fonética construída, se fundem como as notas musicais, costuradas por talentosa harmonia.

Leitão $(2009,83)$ afirma que Noel acolhe o que se vê como erros da gramática popular, para destacar a relação do sentimento e o samba, com efeito, facilmente se confere, não ter tradução, os versos metalinguísticos da composição "Mulata Furzarqueira":

\section{Mulata, vou contar as minhas mágoa}

\footnotetext{
75 Noel Rosa: Poeta da Vila e Cronista do Brasil 2009, p.80
} 


\author{
Meu amor não tem $R$ \\ Mas é amor debaixo d'água \\ Não gosto de te ver sempre a fazer certos papel \\ A se passar pros coronel \\ Nasceste com uma boa sina \\ Se hoje andas bem no luxo \\ É passano a beiçolina ${ }^{76}$
}

Evidenciando o humor e a reflexão da sociedade : haverá acaso amor mais legítimo do que este, que mesmo sem $R$ vale até debaixo d'água?

A sociedade carioca da época é diretamente influenciada pela cultura internacional, fato não o compositor em questão, não permite tal fato passar desapercebido, conforme observamos na reflexão do samba "Não tem tradução", porém, a mensagem apresentada por Noel Rosa, é para a compreensão de todos: o bamba, o bacharel, a moça do cabaré, o malandro, quem vive no morro, no asfalto, não há seleção criteriosa e nem escolha de público restrito como foco.

O processo de criação de Noel Rosa é uma das características marcantes de suas canções, a maneira pela qual se desenvolve suas inovações linguísticas e estilísticas, sempre priorizando a compreensão popular sua matéria temática, de mesma maneira, a inovação vocabular na valorização dos recursos dos recursos de rima favorecendo a melodia, a capacidade do improviso em seus versos, as gírias. É o fortalecimento do processo comunicativo, do coloquialismo em atividade na música popular brasileira.

Para Leitão (2009p. 82), a exaltação rural ou urbana do repertório de Noel sempre esteve atenta à linguagem popular, cuja sintaxe e fonética, além da própria essência rítmica, busca mimetizar, à maneira do programa modernista de 1922. Um princípio que ele explicitará com enorme convicção e lucidez mais tarde, quando já for um nome reconhecido, prestando inestimável contribuição à luta do samba contra o preconceito e criminalização que este ainda padecia no Brasil dos anos 1930:

A princípio o samba foi combatido. Era considerado distração de
vagabundo. Mas estava bem fadado. Desceu do morro, de tamancos,
com o lenço ao pescoço, vagou pelas ruas com um toco de cigarro
apagado no canto da boca e, de repente, ei-lo de fraque e luva branca
nos salóes de Copacabana. Mas o companheiro do samba é o violão,
que já obteve também a sua vitória definitiva. O samba é a voz do

76 Beiçolina: calote Cf. Grande enciclopédia portuguesa e brasileira Editorial Enciclopédia, limitada 2001 
povo. Sem gramática,m sem artifício, sem preconceito, sem mentira. ( "Meia hora com Noel Rosa" Entrevista dada a O Debate, Belo Horizonte, 9 de março de 1935.)

Carvalho \& Araújo (1999,p 78) fazem observações a respeito da maneira muito brasileira da adequação dos pronomes átonos em suas construções, um modo do português falado no Brasil, mais um destaque à moda brasileira. Sem esquecer da influência e poder de comunicação do rádio, pela novidade e força de comunicação, um fator de intensidade sobre a receptividade dessa brasilidade e auto afirmação nacional no contexto de toda influência internacional injetada no Rio de Janeiro.

Como cenário de capital cultural brasileiro, é a expressão da força renovadora da palavra, especialmente aquela das ruas, do cotidiano, da população, dos malandros, da vizinha, do botequim e dos espaços de convivência populares, conforme as reflexões apresentadas a respeito da canção "Conversa de Botequim", a capital fluminense tem a peculiaridade da valorização dos espaços de bares, cafés como referência de samba, de boêmia e consequentemente de integração.

"Olhe aqui, ô Nássara, esse sujeitinho é um danado, ele é o maior poeta popular do Brasil. Ouve só estes dois versos: 'tudo aquilo que o malandro pronuncia, com voz macia / é brasileiro, já passou de português'. Mesmo que esse sujeito tivesse escrito só esses dois versos seria o maior poeta popular do Brasil."

Isso dito por Orestes Barbosa - um talento fora do comum e, mais ainda, um homem sério - tinha peso de lei. ${ }^{77}$

Orestes Barbosa ${ }^{78}$, nascido no mesmo bairro de Noel, era apaixonado pelo pensamento nacionalista; seu interesse concentrava-se na luta pela oficialização de uma língua brasileira que traduzisse a identidade do povo.

Em muitos versos de Noel, Orestes ve presente a questão de seu grande interesse nos

77 Antônio, João 1982, p.03 literatura comentada

78 Uma das manchetes criadas por ele, a pedido de Rui Barbosa, tornou-se célebre: "Cortou o mal pela raiz", anunciava um caso policial em que a esposa cortara o órgão sexual do marido que a havia traído. Trabalhou nos periódicos "A gazeta de Notícias", "A Manhã", "O Radical", "Opinião", "O Mundo", "O Avante", "A Folha", "A Noite", "O Dia", "O Globo" e "A Imprensa"entre outros. Em 1913, quando trabalhava para o jornal "A Noite", de Irineu Marinho, liderou um grupo de repórteres na instalação, no Largo da Carioca, de uma roleta de papelão com o seguinte cartaz: "Jogo é franco - Roleta com 32 números - só ganha freguês". O jornal fazia campanha contra a jogatina desenfreada que ocorria na capital do país, insinuando a conivência das autoridades. Foi esse episódio que inspirou a famosa letra do samba "Pelo telefone", de Donga e Mauro de Almeida: "O Chefe da Polícia pelo telefone mandou avisar/ Que na Carioca tem uma roleta para se jogar...". Foi um jornalista destemido, escrevendo artigos sobre acontecimentos e críticas aos políticos de então. Por causa disso, esteve preso várias vezes. Em 1933, fundou, junto com o amigo e parceiro Nássara, o jornal "A Jornada", que tinha a seguinte epígrafe: "Não quero saber quem descobriu o Brasil; quero saber quem é que bota água no leite." O jornal, que durou poucos meses, dedicava-se a artigos sobre a língua brasileira e a campanhas contra a Light, empresa canadense de energia elétrica. Noel Rosa inclusive, compôs o samba "Não tem tradução", inspirado em uma crítica publicada em "A Jornada", que falava das particularidades do idioma falado no Brasil. Cf. http://dicionariompb.com.br/orestes-barbosa/biografia acesso 15 de junho de 2011 
debates do modernismo: a busca da valorização da linguagem coloquial e a diminuição do distanciamento entre a língua falada e a língua literária. "Orestes Barbosa realiza a associação entre a língua brasileira, o linguajar carioca e o samba, colocando a cidade do Rio de Janeiro como a matriz da nacionalidade brasileira, a cidade-síntese da brasilidade."79

Segundo as considerações de Jorge Caldeira, em suas composições Noel apresenta uma solução estética mais referenciada ao imaginário urbano, incorporando temáticas relacionadas à vida cotidiana da cidade, voltavam-se para maiores audiências. As músicas de Noel eram produzidas para um público anônimo, amplo e impessoal, ou seja, para as massas urbanas. Em samba Noel é simplesmente o músico completo ${ }^{80}$ :

Noel produz muito. Mas tudo que ele faz é bom. Os motivos da correspondência epistolar; os defeitos, os tiques como no "Gago Apaixonado"; as definições científicas; os termos jurídicos e comerciais como no Leilão, surgem nos seus poemas de chefe de escola. É completo. (Barbosa, Orestes, 1978,p. 82)

\subsection{A contribuição de Noel para o samba e o amor pelo Rio de Janeiro}

Considerações de Luiz Tatit $(1995,29)$ sobre Noel e o samba mostram que a canção para Noel era o samba. E samba não era apenas um gênero, um ritmo, uma batida. Tatit concentra-se na análise das criações de Noel encontrando a definição de que para Noel: samba era uma conciliação de tendências opostas: de um lado, a complexidade da vivência pessoal e seu relato preciso e aperiódico, de outro a pulsação regular e os apelos reiterativos das melodias visando a memória do ouvinte e à ginga do corpo.

O desafio de fazer samba era atingir a particularidade das experiências com manobras, sem perder as constâncias musicais do gênero, sobretudo a pulsação periódica da batida. Noel agia como se o samba já existisse plenamente definido. Não se sentia fundador e muito menos inovador. Sentia-se um "bacharel". Diplomado em samba, sem freqüentar escolas de samba. Noel impressiona pela altivez com que tratava o samba. Nunca pôs em dúvida o valor do sambista. Seu orgulho vaza pelos textos e convence o ouvinte pela compatibilidade que mantém com as respectivas melodias. (Tatit,1995,29)

Noel Rosa e Ismael Silva - seu parceiro mais constante - contribuíram significativamente para a evolução formal do gênero. O samba que passaram a fazer, no início dos anos 30 , se distinguiu do samba amaxixado ${ }^{81}$ dos anos 20 , representado sobretudo por

\footnotetext{
79 Barbosa, 2006 p. 7

80 Caldeira, Jorge apud Napolitano, M. Wasserman, M.C. Op. cit., 2007 p. 184

81 Adjetivo: que tem características de maxixe. Cf. Dicionário Unesp de português contemporâneo 2005, p. 60
} 
Sinhô. Esta forma nova, mais domada e refinada - ritmicamente mais próxima do que hoje se reconhece como samba - nasceu entre os sambistas do bairro carioca Estácio de Sá e se espalhou pelo Rio de Janeiro graças, em grande parte, pela dupla de compositores ${ }^{82}$ Dessa forma, consequentemente, ao compositor-letrista, foi concedido ser reconhecido como o primeiro dos nossos cancionistas a desfrutar do status de poeta. De sua maestria e propriedade no uso da linguagem vieram os epítetos com que o batizaram ainda em vida: "filósofo do samba ${ }^{83 "}$ e "poeta da Vila" em referência ao seu bairro, a Vila Isabel.

Noel tratou da identidade nacional e, por extensão, do Brasil. Só que, ao contrário de um mestre do samba-exaltação como Ary Barroso (o autor de “Aquarela do Brasil”), ele nunca foi exaustivo, mas crítico, chegando ao irônico e ao satírico. De olhar aguçado para as mazelas da nação, inaugurou a linha da música de cunho social entre nós (outra razão por que é considerado predecessor de Chico Buarque).

Há autores que o consideram ufanista somente com referência ao seu quintal: a Vila Isabel. Considerando também com grande apreço os bairros: Estácio e Penha, onde o samba (bairro que também tematizado por ele) se desenvolveu e onde e fez vários parceiros na criação de seus sambas. Considerando tais lugares esteticamente privilegiados, Noel fez a apologia da vida dos malandros. A visão que ele passa se alinha com os códigos da malandragem.

Um samba que foi o germe da intensa movimentação que levou Noel Rosa a produzir sambas em louvor a Vila Isabel foi o samba: Na Pavuna ${ }^{84}$. Até o nascimento do Na Pavuna, os bairros e subúrbios não constituíam assunto que interessasse aos compositores. $\mathrm{O}$ êxito do nosso samba despertou a atenção para um novo poético-musical.

Semanas após ter sido lançado, o tal samba sobre a tal bairro do subúrbio, via-se às voltas com vários concorrentes sonoros, que porfiavam em levar para outros bairros as glórias da popularidade maior. Assim surgiu o No Sarguero ${ }^{85}$, de Benedito Lacerda e Ildefonso Norat:

\section{Tava no samba}

\section{Lá no Sarguero}

\footnotetext{
82 No Rio de Janeiro a partir de 1850, mais especificamente nas imediações do Morro da Conceição, Pedra do Sal, Praça Mauá, Praça XI, Cidade Nova, Saúde e Zona Portuária, foi crescendo a população de negros e mestiços oriundos de várias partes do Brasil, principalmente da Bahia, bem como de ex-soldados da Guerra de Canudos. Estes últimos viriam a formar uma comunidade que eles próprios denominaram de "Favela" termo que posteriormente viria a ser usado como sinônimo de construções irregulares das classes menos favorecidas. In vocábulo "samba" - acesso em 14/03/2011 http://www.dicionariompb.com.br/busca

83 Cf. A mpb na era do rádio, Sérgio Cabral 1996, p. 64

84 Na Pavuna Almirante / Homero Dornelas 193078 RPM

85 No Sarguêro Ildefonso Norat / Benedito Lacerda 193078 RPM
} 
Veio a polícia

Me levou no tintureiro.

Outro bairro muito considerado por Noel depois da Vila, ou ainda, um dos mais homenageados por ele, é a Penha, Noel mencionada por ele em oito composições: sete sambas e uma embolada. Eis os títulos: "Cumprindo a promessa" (1929), "Fiquei rachando lenha” (c/ H. Cordovil, 1934) “Meu barração”(1933), “Eu agora fiquei mal” (c/ A Gargalha, 1931), “Chuva de vento" (embolada, 1937) e o clássico "Feitio de oração" (c/ Vadico,1933):

Batuque é um privilégio

Ninguém aprende samba no colégio

Por isso agora

Lá na Penha vou mandar

Minha morena pra cantar

Com satisfação

A cidade do Rio de Janeiro não foi esquecida por Noel que a homenageia com a marcha "Cidade mulher" (1936):

\author{
Cidade notável \\ Inimitável \\ Maior e mais bela que outra qualquer \\ Cidade sensivel \\ Irresistivel
}

Cidade do amor, cidade mulher

No que toca aos Estados, a Bahia recebeu a homenagem de Noel em dois sambas: "Dona do lugar" (c/ I. Silva e F. Alves, 1933) e o singelo, mas significativo "Na Bahia" (c/ Zequinha de Abreu, 1936), gravado somente em 1983 pelo Conjunto "Coisas Nossas":

Aonde é que o nosso grande Brasil principia? 
Na Bahia! Na Bahia!

Aonde foi que Jesus pregou sua filosofia?

Na Bahia! Na Bahia! ${ }^{86}$

$\overline{86}$ Cf. Carvalho \& Araujo 1999, p. 128 


\section{O SAMBA NÃO TEM TRADUÇÃO}

\subsection{O corpus da pesquisa}

Concentra-se neste capítulo o grupo de canções escolhidas para a análise dos temas citados anteriormente. Este é o corpus da pesquisa selecionado mediante as considerações de adequação as especificações temáticas. As observações dos pontos denominados como facetas de Noel Rosa, nos serviram de introdução para a apresentação das canções separadas em sete grupos temáticos: autobiografia,retratos de mulher, o carinho de Noel pelos bairros do Rio de Janeiro e sua amada Vila Isabel, o observador atento da sociedade, sobre as questões que lhe conferem o epíteto de filósofo do samba, sua posição humorista e satírico em muitos momentos e por fim a crônica representada na sua composição.

A opção por Noel Rosa se justifica por sua diversidade temática, da importância e riqueza de sua música para a época para a música brasileira. Sendo Noel um compositor da chamada fase áurea da música no Brasil, ele se destaca por seus muitos temas destacando o talento no número de suas quase 300 canções registradas legalmente em cartórios, e conforme Máximo \& Didier (1990) a ele se confere a o título de maior compositor do Brasil.

Sua obra abrange vários aspectos, toda essa diversidade propícia ainda espaço para a descoberta de outros temas e tantas especificações. Para uma fundamentação metodológica mediante o tempo de pesquisa para a elaboração deste trabalho, o processo de execução fixou a análise dos temas apresentados partindo da seleção das composições escolhendo-as com foco temático.

Os textos escolhidos, são todos da autoria do compositor. Alguns em parceria com outros sambistas, porém todos registrados no nome de Noel Rosa. Outro fator sobre o critério de escolha, sobre os temas, se percebe em muitas canções que Noel fala de política, do cotidiano, de si mesmo com humor, revelando assim uma fusão do que a pesquisa compreende como temas.

Para a elaboração do corpus, com intuito de conhecer um pouco mais sobre o cenário que os textos apresentam, sobre as personagens que neles figuram, o cenário que apresentam e algumas questões da época que mencionam, partindo da biografia apresentada, com destaque ao referencial teórico da elaboração dessa pesquisa: João Máximo e Carlos Didier, seus biógrafos mais completos. A relação que apresentam permite fazer descobertas de relação apresentada pelos autores ligando "vida e obra" do compositor em questão, auxiliando 
compreender muitos dos temas expostos por Noel em suas letras.

Para favorecer a compreensão dos textos aqui mencionados, e o quanto revelam sobre as diversas questões da realidade da capital fluminense na década de 1920 / 30 o contexto apresentado, a visão política de Noel aparecendo na base do que é apresentado como pensamento do povo, os problemas da vida cotidiana, analfabetismo, jogo do bicho, bebida, fumo, a fome e as dificuldades do baixo salário.

A apresentação desse cenário, chega na música brasileira, consequentemente para no rádio ganhando assim a identificação do povo, se sente representado na expressão de suas composições. Para a época, para a música e para o samba, que vive o momento de sua consolidação, a compreensão da música de Noel mistura costumes da sociedade e do morro, sempre dando destaque na valorização do cotidiano.

As composições do corpus deste trabalho, apresentam seus registros referentes a: gravação, datas, número de registro de LP's e demais dados conforme constam os registros, seguidos pelo Instituto Memória Musical Brasileira (IMMUB) e Impressa Oficial disponibilizados no site http://www.memoriamusical.com.br/. Situado no Rio de Janeiro capital, o Instituto é uma organização sem fins lucrativos e conta com fidedigna fonte para estudos de música brasileira sendo seu destaque o acervo de discografia. A orientação para obter tais dados obtive do acervo do Museu da Imagem e do Som (MIS) capital fluminense que tem por fonte de informações os registros do mesmo site.

Há lançamentos no mercado fonográfico de gravações de sucessos de Noel Rosa, tanto da década de 1920 / 30 como também de composições póstumas, esse fato leva muitas pessoas a entrem em contato com Noel Rosa, e representam uma oportunidade de conhecê-lo por meio da gravação dos interpretes contemporâneos.

Essas novas regravações, propagam a lembrança e a mensagem de Noel, as canções selecionadas para fazer parte do corpus do trabalho, discutem principalmente os pontos relevantes do conjunto da obra noelina, mostra os temas mais relevantes no que se refere a sua biografia e suas características mais marcantes: o a observação do cotidiano e seu humor.

A seguir, a apresentação das vinte e uma canções que compõem o corpus desta pesquisa: 


\section{Pela décima vez ${ }^{1}$}

Jurei não mais amar pela décima vez

Jurei não perdoar o que ela me fez

O costume é a força que fala mais forte do que a natureza

E nos faz dar prova de fraqueza

Joguei meu cigarro no chão e pisei

Sem mais nenhum aquele mesmo apanhei e fumei

Através da fumaça neguei minha raça chorando, a repetir:

Ela é o veneno que eu escolhi para morrer sem sentir

Senti que meu coração quis parar

Quando voltei e escutei a vizinhança falar

Que ela só de pirraça seguiu com um praça ficando lá no xadrez

Pela décima vez ela está inocente nem sabe o que fez

Pela décima vez Noel Rosa /1935

78 RPM - Aracy de Almeida

(1947) Odeon 12.804-a

Fonte impressa: Chediak 1991, p. 88 


\section{Eu sei sofrer ${ }^{1}$}

Quem é que já sofreu mais do que eu?

Quem é que já me viu chorar?

Sofrer foi o prazer que Deus me deu,

Eu sei sofrer sem reclamar.

Quem sofreu mais que eu não nasceu,

Com certeza Deus já me esqueceu.

Mesmo assim não cansei de viver,

E na dor eu encontro prazer.

Saber sofrer é uma arte

E pondo a modéstia de parte,

Eu posso dizer que sei sofrer.

Quanta gente que nunca sofreu,

Sem sentir, muitos prantos verteu.

Já fui amado, enganado,

Senti quando fui desprezado,

Ninguém padeceu mais do que eu.

$1 \quad$ Eu sei sofrer Noel Rosa /1937

78 RPM - Aracy de Almeida

(1936) Victor 34.176-a . Samba

Fonte impressa: Máximo \& Didier 1990, p. 450 


\section{Fita amarela ${ }^{1}$}

Quando eu morrer

Não quero choro nem vela

Quero uma fita amarela

Gravada com o nome dela

Se existe alma

Se há outra encarnação

Eu queria que a mulata

Sapateasse no meu caixão

Não quero flores, Nem coroa de espinho Só quero choro de flauta, Com violão e cavaquinho

\section{Estou contente}

Consolado por saber

Que as morenas tão formosas

A terra um dia vai comer

Não tenho herdeiros

Não possuo um só vintém

Eu vivi devendo a todos

Mas não paguei nada a ninguém

Meus inimigos

Que hoje falam mal de mim

Vão dizer que nunca viram

Uma pessoa tão boa assim

Quero que o sol

Não visite o meu caixão

Para a minha pobre alma

Não morrer de insolação ${ }^{2}$

$1 \quad$ Fita Amarela Noel Rosa 1933

78 RPM Francisco Alves / Mário Reis.

(1933)Odeon 10.961-a - Samba

Fonte impressa: Máximo \& Didier 1990, p. 254

2 Quadrinhas muitas vezes improvisadas em bares e programas de rádio, uma ou outra fadada a permanecer esquecida. 


\section{Dama do cabaré 1}

Foi num cabaré na Lapa ${ }^{2}$

Que eu conheci você

Fumando cigarro,

Entornando champanhe no seu soirée ${ }^{3}$

Dançamos um samba,

Trocamos um tango por uma palestra

Só saímos de lá meia hora

Depois de descer a orquestra

Em frente à porta um bom carro nos esperava

Mas você se despediu e foi pra casa a pé

No outro dia lá nos $\operatorname{Arcos}^{4}$ eu andava

À procura da Dama do Cabaré

Eu não sei bem se chorei no momento em que lia

A carta que recebi, não me lembro de quem

Você nela me dizia que quem é da boêmia

Usa e abusa da diplomacia

Mas não gosta de ninguém

Foi num cabaré na Lapa...

1 Dama do Cabaré Noel Rosa 1936

78 RPM Orlando Silva .

(1936) Victor 34.085-a . Samba

Fonte impressa: Máximo \& Didier 1990, p. 316

2 Bairro boemio do Rio de Janeiro, autentico reduto de boemios, malandros sambista, mulheres famosas artistas e intelectuais, principalmente na época de Noel. Famoso por seus cabarés hoje extintos e vida noturna.

3 nf. Noitada, serão. Reunião social, ou de outro tipo, que ocorre à noite. Cf. Dicionário Michaelis ,2004

4 Arcos da Lapa. Famoso arqueoduto carioca, construído entre 1719 e 1723 e reformado em 1750. Somente em 1896 foi transformado em viaduto por onde correm os bondinhos de Santa Tereza. Um dos maiores monumentos arquitônicos do Rio de Janeiro. 


\section{Três apitos ${ }^{1}$}

Quando o apito

Da fábrica de tecidos

Vem ferir os meus ouvidos

Eu me lembro de você

Mas você anda

Sem dúvida bem zangada

E está interessada

Em fingir que não me vê

Você que atende ao apito

De uma chaminé de barro

Por que não atende ao grito tão aflito

Da buzina do meu carro?

Você no inverno

Sem meias vai pro trabalho

Não faz fé com agasalho

Nem no frio você crê

Mas você é mesmo

Artigo que não se imita

Quando a fábrica apita

Faz réclame de você.

Sou do sereno

Poeta muito soturno

Vou virar guarda-noturno

E você sabe por quê

Mas você não sabe

Que enquanto você faz pano

Faço junto do piano

Estes versos pra você

Nos meus olhos você vê

Que eu sofro cruelmente

Com ciúmes do gerente impertinente

Que dá ordens a você.

1 Três Apitos Noel Rosa 1951

78 RPM Roberto Paiva

(1951) Sinter 00-00.076-a

Fonte impressa: Máximo \& Didier 1990, p.184 


\section{Último desejo $^{1}$}

Nosso amor que eu não esqueço, e que teve o seu começo

Numa festa de São João

Morre hoje sem foguete, sem retrato e sem bilhete, sem luar, sem violão

Perto de você me calo, tudo penso e nada falo

Tenho medo de chorar

Nunca mais quero o seu beijo mas meu último desejo

você não pode negar

Se alguma pessoa amiga pedir que você

lhe diga

Se você me quer ou não, diga que você

me adora

Que você lamenta e chora a nossa separação

Às pessoas que eu detesto, diga sempre que eu não presto

Que meu lar é o botequim, que eu arruinei sua vida

Que eu não mereço a comida que você pagou pra mim 


\section{Eu vou pra Vila ${ }^{1}$}

Não tenho medo de bamba

$\mathrm{Na}$ roda de samba

Eu sou bacharel

(Sou bacharel)

Andando pela batucada

Onde eu vi gente levada

Foi lá em Vila Isabel

$\mathrm{Na}$ Pavuna tem turuna

$\mathrm{Na}$ Gamboa gente boa

Eu vou pra Vila

Aonde o samba é da coroa.

Já saí de Piedade

Já mudei de Cascadura

Eu vou pra Vila

Pois quem é bom não se mistura

Quando eu me formei no samba

Recebi uma medalha

Eu vou pra Vila

Pro samba do chapéu de palha.

A polícia em toda a zona

Proibiu a batucada

Eu vou pra Vila

Onde a polícia é camarada.

1 Eu vou pra Vila Noel Rosa 1931

78 RPM Almirante

(1931) Parlophon 13.256-a

Fonte impressa: Máximo \& Didier 1990, p. 137 
Feitiço da Vila ${ }^{1}$

Quem nasce lá na Vila

Nem sequer vacila

Ao abraçar o samba

Que faz dançar os galhos,

Do arvoredo e faz a lua,

Nascer mais cedo.

Lá, em Vila Isabel,

Quem é bacharel

Não tem medo de bamba.

São Paulo dá café,

Minas dá leite,

E a Vila Isabel dá samba.

A Vila tem um feitiço sem farofa

Sem vela e sem vintém

Que nos faz bem

Tendo nome de princesa

Transformou o samba

Num feitiço descente

Que prende a gente

O sol da Vila é triste

Samba não assiste

Porque a gente implora:

"Sol, pelo amor de Deus,

não vem agora

que as morenas

vão $\log o$ embora

Eu sei tudo o que faço

sei por onde passo

paixão não me aniquila

Mas, tenho que dizer, modéstia à parte, meus senhores,

Eu sou da Vila!

1 Feitiço da Vila Noel Rosa / Vadico 1934

78 RPM João Petra de Barros

(1934) Odeon 11.175-a

Fonte impressa: Máximo \& Didier 1990, p.329 


\section{Palpite infeliz ${ }^{1}$}

Quem é você que não sabe o que diz?

Meu Deus do Céu, que palpite infeliz!

Salve Estácio, Salgueiro, Mangueira,

Oswaldo Cruz e Matriz

Que sempre souberam muito bem

Que a Vila Não quer abafar ninguém,

Só quer mostrar que faz samba também

Fazer poema lá na Vila é um brinquedo

Ao som do samba dança até o arvoredo

Eu já chamei você pra ver

Você não viu porque não quis

Quem é você que não sabe o que diz?

A Vila é uma cidade independente

Que tira samba mas não quer tirar patente

Pra que ligar a quem não sabe

Aonde tem o seu nariz?

Quem é você que não sabe o que diz? 


\section{Onde está a honestidade? ${ }^{1}$}

Você tem palacete reluzente

Tem jóias e criados à vontade

Sem ter nenhuma herança ou parente

Só anda de automóvel na cidade...

E o povo já pergunta com maldade:

Onde está a honestidade?

Onde está a honestidade?

O seu dinheiro nasce de repente

E embora não se saiba se é verdade

Você acha nas ruas diariamente

Anéis, dinheiro e felicidade...

Vassoura dos salões da sociedade

Que varre o que encontrar em sua frente

Promove festivais de caridade

Em nome de qualquer defunto ausente...

1 Onde Está a Honestidade Noel Rosa 1933

78 RPM Noel Rosa

(1933) Odeon 10.989-a . Samba

Fonte impressa: Máximo \& Didier 1990, p. 242 


\title{
O orvalho vem caindo ${ }^{1}$
}

\author{
O orvalho vem caindo,
}

vai molhar o meu chapéu

e também vão sumindo,

as estrelas lá do céu...

Tenho passado tão mal:

A minha cama é uma folha de jornal!

Meu cortinado é um vasto céu de anil

E o meu despertador é o guarda-civil

(Que o salário ainda não viu!)

A minha terra dá banana e aipim

Meu trabalho é achar quem

[descasque por mim

(Vivo triste mesmo assim!)

A minha sopa não tem osso e nem tem

[ sal,

Se um dia passo bem, dois e três

[passo mal

(Isso é muito natural!)

1 O Orvalho Vem Caindo Noel Rosa / Kid Pepe 1934

78 RPM Almirante

(1934) Victor 33.734-a

Fonte impressa: Máximo \& Didier 1990, p. 272 


\section{Samba da boa vontade ${ }^{1}$}

(Campanha da boa vontade)

Viver alegre hoje é preciso

Conserva sempre o teu sorriso

Mesmo que a vida esteja feia

E que vivas na pirimba ${ }^{2}$

Passando a pirão de areia

Gastei o teu dinheiro

Mas não tive compaixão

Porque tenho a certeza

Que ele volta à tua mão

Se ele acaso não voltar

$\mathrm{Eu}$ te pago com sorriso

E o recibo hás de passar

(Nesta questão solução sei dar)

Neste Brasil tão grande

Não se deve ser mesquinho

Quem ganha na avareza

Sempre perde no carinho

Não admito minharia ${ }^{3}$

Pois qualquer economia

Sempre acaba em porcaria

(Minha barriga não está vazia)

Comparo o meu Brasil

A uma criança perdulária

Que anda sem vintém

Mas tem a mãe que é milionária

E que jurou batendo o pé

Que iremos à Europa

Num aterro de café

(Nisto eu sempre tive fé)

1 Samba da Boa Vontade Noel Rosa / João de Barro 1931

78 RPM Noel Rosa / João de Barro

(1931) Parlophon 13.344-a

Fonte impressa: Máximo \& Didier 1990, p. 170

2 Gíria da época hoje equivalente ao sentido de pindaiba: falta de dinheiro Cf. Ferreira, 2004

3 Gíria da época hoje equivalente ao sentido de ninharia: coisa sem valor, insignificância. Borba, 2004 


\section{Feitio de oração ${ }^{1}$}

Quem acha vive se perdendo

Por isso agora eu vou me defendendo

Da dor tão cruel desta saudade

Que, por infelicidade

Meu pobre peito invade

Batuque é um privilégio

Ninguém aprende samba no colégio

Sambar é chorar de alegria

É sorrir de nostalgia

Dentro da melodia

Por isso agora

Lá na Penha vou mandar

Minha morena pra cantar

Com satisfação

E com harmonia

Esta triste melodia

Que é meu samba

Em feito de oração

O samba na realidade

Não vem do morro nem lá da cidade

E quem suportar uma paixão

Sentirá que o samba então

Nasce do coração.

1 Feitio de Oração Noel Rosa / Vadico 1933

78 RPM Francisco Alves / Castro Barbosa

(1933) Odeon 11.042-a Samba

Fonte impressa: Máximo \& Didier 1990, p. 267 


\section{Silêncio de um minuto ${ }^{1}$}

Não te vejo e não te escuto,

O meu samba está de luto.

Eu peço o silêncio de um minuto,

Homenagem a história.

De um amor cheio de glória

Que me pesa na memória.

Nosso amor cheio de glória,

De prazer e de ilusão,

Foi vencido e a vitória

Cabe à tua ingratidão.

Tu cavaste a minha dor

Com a pá do fingimento

E cobriste o nosso amor

Com a cal do esquecimento.

Teu silêncio absoluto

Obrigou-me a confessar

Que o meu samba está de luto,

Meu violão vai soluçar.

Luto preto é vaidade,

Neste funeral de amor,

O meu luto é saudade

E saudade não tem cor.

1 Silêncio de Um Minuto Noel Rosa 1940

78 RPM Marília Batista

(1940) Victor 34.604-a . Samba

Fonte impressa: Máximo \& Didier 1990, p. 366 


\section{Filosofia $^{1}$}

O mundo me condena,

e ninguém tem pena

Falando sempre mal do meu nome.

Deixando de saber

se eu vou morrer de sede

Ou se vou morrer de fome.

Mas a filosofia

Hoje me auxilia

A viver indiferente assim.

Nesta prontidão sem fim,

Vou fingindo que sou rico,

Pra ninguém zombar de mim.

Não me incomodo

Que você me diga

Que a sociedade é minha inimiga.

Pois cantando neste mundo

Vivo escravo do meu samba,

Muito embora vagabundo.

Quanto a você

Da aristocracia,

Que tem dinheiro

Mas não compra alegria,

Há de viver eternamente

Sendo escrava dessa gente

Que cultiva hipocrisia.

1 Filosofia Noel Rosa / André Filho 1933

78 RPM Mário Reis

(1933) Columbia 22.225-B

Fonte impressa: Máximo \& Didier 1990, p. 259 


\section{Não tem tradução ${ }^{1}$}

O cinema falado

é o grande culpado

Da transformação

Dessa gente que sente

Que um barracão

Prende mais que o xadrez

Lá no morro, seu eu fizer uma falseta,

A Risoleta

desiste logo do francês e do Inglês.

A gíria que o nosso morro criou

Bem cedo a cidade aceitou e usou.

Mais tarde o malandro deixou de sambar,

Dando pinote

Na gafieira dançar o Fox-Trot! ${ }^{2}$

Essa gente hoje em dia

que tem a mania

Da exibição

Não entende que o samba

Não tem tradução

No idioma francês.

Tudo aquilo que o malandro pronuncia,

Com voz macia,

É brasileiro, já passou de português.

Amor, lá no morro, é amor pra chuchu,

As rimas do samba não são "I love you".

E esse negócio de "alô", "alô , boy"

"Alô Johnny"

Só pode ser conversa de telefone...

1 Não Tem Tradução Noel Rosa 1933

78 RPM Francisco Alves

(1933) Odeon 11.057-a . Samba

Fonte impressa: Máximo \& Didier 1990, p. 243

2 Dança e gênero de música dos negros americanos que se popularizou um tempo no Brasil, em compasso quaternário, movimento rápido e aparentada com o Jazz. O foxtrote execssivamente rápido para dançar foi também conhecido como stomp. Andrade, 1999 


\section{Seu Jacinto ${ }^{87}$}

O que eu sinto e não consinto

É seu cinto se afrouxar

Seu Jacinto aperta o cinto

Bota as calças no lugar.

O seu Jacinto tinha que comprar feijão

Mas não tinha um só tostão

E o caixeiro estava duro

Ele não gosta de pagar feijão à vista

Porque sendo futurista

Paga sempre pro futuro.

O seu Jacinto que é cheio de chiquê

Eu não sei dizer por que

Dorme de cartola e fraque

Anda dizendo que o seu sonho dourado

É morrer esmigalhado

Por um carro Cadillac

O seu Jacinto já arranca a sobrancelha

E só bebe mel de abelha

Para ser um doce amor

A tia dele que até hoje é melindrosa

Quer ser leve e vaporosa

E tomar banho de vapor.

Quando tem baile lá na casa da Teresa

Ela faz pano de mesa

Com o lençol que cobre a cama

Bota nos copos água usada na banheira

Depois diz à turma inteira

Que é cerveja lá da Brahma

87 Seu Jacinto Noel Rosa 1933

78 RPM Noel Rosa / Ismael Silva

(1933) Odeon 10.953-a . Samba

Fonte impressa: Máximo \& Didier 1990, p. 231 


\section{Gago apaixonado ${ }^{1}$}

Mu-mu-mulher, em mim fi-fizeste um estrago

$\mathrm{Eu}$ de nervoso estou-tou fi-ficando gago

Não po-posso com a cru-crueldade da saudade

Que que mal-maldade, vi-vivo sem afago

Tem tem pe-pena deste mo-moribundo

Que que já virou va-va-va-va-ga-gabundo

Só só só só por ter so-so-sofri-frido

Tu tu tu tu tu tu tu tu

Tu tens um co-coração fi-fi-fingido

Mu-mu-mulher, em mim fi-fizeste um estrago

Eu de nervoso estou-tou fi-ficando gago

Não po-posso com a cru-crueldade da saudade

Que que mal-maldade, vi-vivo sem afago

Teu teu co-coração me entregaste

De-de-pois-pois de mim tu to-toma-maste

Tu-tua falsi-si-sidade é pro-profunda

Tu tu tu tu tu tu tu tu

Tu vais fi-fi-ficar corcunda!

1 Gago Apaixonado Noel Rosa 1931

78 RPM Noel Rosa

(1931) Columbia 22.023-B

Fonte impressa: Máximo \& Didier 1990, p. 166 


\section{Século do progresso ${ }^{1}$}

A noite estava estrelada

Quando a roda se formou

A lua veio atrasada

E o samba começou

Um tiro a pouca distância

No espaço, forte, ecoou

Mas ninguém deu importância

E o samba continuou.

Entretanto, ali bem perto

Morria de um tiro certo

Um valente muito sério

Professor dos desacatos

Que ensinava aos pacatos

$\mathrm{O}$ rumo do cemitério

Chegou alguém apressado

Naquele samba animado

Que cantando assim dizia:

"No século do progresso

$\mathrm{O}$ revólver teve ingresso

Pra acabar com a valentia."

1 Século do Progresso - Noel Rosa 1938

78 RPM Aracy de Almeida

(1938) Victor 34.296-a

Fonte impressa: Máximo \& Didier 1990, p. 295 


\section{Rapaz folgado ${ }^{1}$}

Deixa de arrastar o teu tamanco

Pois tamanco nunca foi sandália

E tira do pescoço o lenço branco

Compra sapato e gravata

Joga fora esta navalha que te atrapalha

Com chapéu do lado deste rata

Da polícia quero que escapes

Fazendo um samba-canção

Já te dei papel e lápis

Arranja um amor e um violão

Malandro é palavra derrotista

Que só serve pra tirar

Todo o valor do sambista

Proponho ao povo civilizado

Não te chamar de malandro

E sim de rapaz folgado

$1 \quad$ Rapaz Folgado Noel Rosa 1938

78 RPM Aracy de Almeida

(1938) Victor 34.368-a

Fonte impressa: Máximo \& Didier 1990, p. 292 


\section{Conversa de botequim ${ }^{1}$}

Seu garçom, faça o favor

De me trazer depressa

Uma boa média que não seja requentada,

Um pão bem quente com manteiga à beça ${ }^{2}$,

Um guardanapo

Um copo d'água bem gelada.

Fecha a porta da direita

Com muito cuidado

Que eu não estou disposto

A ficar exposto ao Sol.

Vá perguntar ao seu freguês do lado

Qual foi o resultado do futebol.

Se você ficar limpando a mesa, Não me levanto nem pago a despesa.

Vá pedir ao seu patrão

Uma caneta, um tinteiro,

Um envelope e um cartão.

Não se esqueça de me dar palitos

E um cigarro pra espantar mosquitos.

Vá dizer ao charuteiro

Que me empreste uma revistas

Um isqueiro e um cinzeiro.

Telefone ao menos uma vez

Para 344333

E ordene ao Seu Osório

Que me mande um guarda-chuva

Aqui pro nosso escritório.

Seu garçom me empresta algum

[dinheiro

Que eu deixei o meu com o bicheiro,

Vá dizer ao seu gerente

Que pendura essa despesa

No cabide ali em frente.

1 Conversa de Botequim Noel Rosa / Vadico 1935

78 RPM Noel Rosa

(1935) Odeon 11.257-a

Fonte impressa: Máximo \& Didier 1990, p. 398

2 Expressão da época, gíria equivalente a muito, bastante. 


\section{2 Análise do corpus}

A análise do corpus segue a ordem da apresentação das canções, o critério estabelecido se concentra nas questões temáticas.

\subsubsection{Noel por ele mesmo: os traços biográficos na música de Noel Rosa}

As letras escolhidas para propor uma reflexão sobre o tema "Noel por ele mesmo", são as seguintes canções: "Pela décima vez", "Eu sei sofrer" e "Fita amarela". Apresentam a primeira pessoa e além disso descrevem sentimentos, passagens biográficas tais como mencionam as referências de suas entrevistas e depoimentos, ou seja é "Noel por ele mesmo", pelas suas próprias declarações.

\section{Pela décima vez.}

É a reflexão sobre o amor e sobre o erro enfatizando o fato de o ser humano insistentemente cometê-la ao longo de uma vida. Utilizando a imagem de um homem que sofre por esse sentimento. O compositor apresenta um homem sem domínio de si por duas forças avassaladoras: amor e natureza. Em rimas AABB a construção acentuou a contraposição central da letra da canção: natureza $x$ fraqueza. Apontado como uma grande armadilha, tal sentimento o leva a admitir a repetição de um erro - a quebra de um juramento que comete pela décima vez.

O homem segue, cumprindo seu destino ao lado da mulher enganadora. Agora tem consciência das traições e aceita, repetindo o erro, que revela o sintoma de sua angústia. Repetindo o erro "pela décima vez", porque mudar está acima do cogito iluminista da razão. A palavra-chave do texto é a repetição, que já no título, define o seu destino trágico, num movimento, sem possibilidades de alteração. Romântico, irônico e desenganado, ele vai ao inconsciente, para dar o jeito de perdoar porque ela "Não sabe o que fez", porque também não é consciente da repetição do ato de trair: são dois personagens trágicos que se encontram. (Monteiro 2000, p.37)

Julinha, Josefina - Fina, Clara, Lindaura, Ceci. Estes nomes apontam alguns dos vários casos de amor nas estórias do compositor. A letra faz referência a uma pessoa que tem 
consciência de que lhe faz mal, sobrepondo-o a fraqueza, resignando-o a uma natureza dominante que aparece na voz da canção. Segue em busca do que reconhece ser o veneno de sua escolha.

Pouco antes, ao Jornal de Rádio de $1^{\circ}$ de Janeiro de 1935, Noel tinha sido claro ao apontar "Pela décima vez" seu samba favorito: "É a melodia que fala mais à minha alma, que me sugestiona mais poderosamente a imaginação, que acorda em mim o desejo do sonho. Fiz "Pela Décima Vez" com verdadeiro cainho artístico, procurando fixar, malgrado a aparente leveza do tema, um verdadeiro drama do coração" (Máximo \& Didier 1990, p. 359)

A reflexão do amor como fraqueza humana é utilizada para sintetizar um fato constante e muito presente em Noel: a contradição. As mostras de fraqueza da personagem que retrata se acentuam nas cenas apresentadas.

O que Noel tem de mais universal, não está na descrição dos tipos de sua cidade, todos eles dados históricos, mas a formulação musical e poética, dos paradoxos do amor, seus gestos inconsequentes, suas idiossincrasias, suas paixões.

( Neto 1998, p. 140 )

O amor em todo contexto e logo de princípio aparece como vício de Noel e este vício traz o registro da limitação do ser humano ante algo que, no segundo momento, se concentra no cigarro. Essa tendência e propensão ao mal, faz com que a personagem se sujeite a não ter força mais uma vez, sentindo-se dominado. A fraqueza, agora materializada em um objeto, passa a ideia de que o homem se submete a qualquer coisa pela força do costume, como cita no terceiro verso.

\section{Eu sei sofrer}

Há inferências de um registro do compositor relatando suas desventuras sobre si mesmo. Seus problemas no queixo gerando embaraço em relações pessoais e amorosas, as dificuldades financeiras registradas em tantos momentos de sua vida em suas letras e biografia, seus conflitos amorosos e sua saúde afetada pela tuberculose custando-lhe noites de boêmia em sacrifícios para sua recomposição.

"Eu sei sofrer" é uma narrativa de antíteses: sofrer e prazer. Dor e alegria são faces de uma mesma moeda. A dor aparece como a companheira mais contumaz, como aquela que 
melhor ensina ao homem a reflexão mas, sem medo de um diálogo em que a condição para se aprender é a aproximação. Sem dor não existiria felicidade, que é o ponto de chegada de quem vai ao encontro de qualquer questão de vida. Sofrer para Noel representa o contexto de um jogo: vida e sorte. Em ambos esta o sofrer. $\mathrm{O}$ seu problema físico: ocasionando vários problemas de mastigação, a deformação de seu queixo, a vergonha do deboche na infância, o medo ao desprezo na adolescência, amores e paixões mal compreendidas, e a moeda sempre lhe cai na mão na face visível da dor.

Noel entra em cena, miúdo, magro, aparência insignificante de sempre. Põe o pé na cadeira, pega o violão e começa a cantar. Lá das torrinhas, novo grito:

“- Cuidado para não cair do queixo!”

Gargalhadas. Noel para. Espera que o silêncio se restabeleça e só então continua. É animada a viagem de volta ao Rio, a bordo de uma bordejante barca da Cantareira. Uns cantam, outros conversam, todos riem. Newton Teixeira nota que Noel se afastou, foi lá para a popa, sozinho, olhar o mar que a embarcação deixa para trás num rastro de espuma. Pensa em se aproximar, mas desiste. Noel está triste, não é o mesmo da viagem de ida. Se foi o grito da arquibancada que o perturbou("Cuidado para não cair do queixo"), Newton não tem coragem de perguntar. $\mathrm{O}$ fato é que, depois desta noite, nunca mais um circo - cujo público dá tanta alegria a tanto artista - terá de novo o privilégio de contar com o canto de Noel.

Às vezes se importa, às vezes não. Suas reações às referências e eventuais brincadeiras que se fazem ao queixo defeituoso também são imprevisíveis. Pode ser que não ligue ou até participe delas, usando a boca torta para bancar o ventríloquo como nos tempos de ginásio e assim mexer com os amigos, os músicos, os garçons. (Máximo \& Didier 1990,p.419)

Vasconcelos (2004), soma a estes fatos que influenciaram sua vida: as dificuldades financeiras, dia a dia enfrentadas por seu pai com muita honestidade até sua morte (suicídio) precedida de crises de depressão e desanimo, em decorrência de desgostos enfrentados pelas irregularidades com as quais ele não concordava em seu emprego. Vasconcelos cita também compra do carro apelidado de "Pavão" e com a dívida contraída, acelerou de sua produção musical.

Noel em Friburgo, tomado pelas dificuldades que a doença lhe traz: a falta de ar, longe da Lapa, dos amigos, da cidade do Rio de Janeiro, não se nega a cantar um samba aos que lhe visitavam, mesmo com a voz muito fraca, sem sair da espreguiçadeira, num samba triste, banhado em dor, de acordo com os relatos de seus biógrafos. 
Os pronomes: eu e meu juntamente com os verbos: deu, cansei, posso dizer são os distintivos de sua própria vida destacando-se aquele que é identificado pelo seu sofrimento. Noel utiliza-se de uma identificação de “esquecido por Deus” e nisso sintetiza a sua personalidade na canção.

Apontado como um poeta da alegria, do deboche, da ironia, do sarcasmo, da irreverência e do humor, traz a alma profundamente dorida. Outra marca que o persegue são suas desventuras amorosas e sobretudo, com a boêmia, a vida na noite, no sereno o levam a ficar doente do pulmão. Vitima da tuberculose, numa época em que ainda não havia penicilina. A cerveja, o amor, a paixão e a lua, que iluminam o Rio e convidam ao samba.

Máximo \& Didier (1990) mostram que não há de fato uma representação de Noel reclamando, manifestando-se a alguém com indignação ou alteração, surtos de cólera ou algo parecido, ao contrário:

\footnotetext{
"Tenho pena daqueles que estou incomodando com a minha mercida moléstia. Confesso que não sei agradecer a tanta bondade . Era mais negócio vocês me deixarem morrer, como eu mereço. Não quero mais amolar.." (Máximo \& Didier 1990, p. 451 apud No Tempo de Noel Rosa, primeira edição. 201 e segunda 211)
}

\section{Fita amarela}

A ilustração encontrada em "Fita amarela" é a junção do paradoxo: vida e morte presente em todas as estrofes por meio da citação de elementos que se contrapõem. É um autor anunciando a descrição do desejo de não deixar tristeza em sua despedida dessa vida e uma carta de recomendação para seus amigos de como proceder no momento de sua partida desse mundo.

Remetendo a ideia de um testamento, "Fita amarela" tra ironia, bom criatividade e destaque pela sua originalidade em relação a época. $\mathrm{O}$ uso do futuro do subjuntivo é recorrente na época com a assimilação de pensamento da morte:

Os sambista, principalmente os dos morros, sempre foram muito ligados ao tema, simulando diante da morte mais coragem do que realmente têm, fingindo-se superiores a ela, salpicando-a de humor como se isso, afinal, pudesse mantê-la longe. São inúmeros os exemplos de estribilhos criados a partir destes testamentos poéticos, em torno dos quais os sambistas improvisam interminável versalhada. (...) Tema muito explorado, seja por poetas conhecidos, seja por sambistas anôni, é um mote, pode-se dizer, de domínio público. (Máximo \& Didier 1990 p. 255)

Há uma marca de contraste na junção de elementos metafísicos apresentados como: 
alma, encarnação, a reflexão da própria morte, porém, há uma imagem construída de consolo e alegria por meio da consciência da efemeridade atestando a fugacidade da beleza.

\author{
Alegria \\ sapateado da mulata \\ choro de flauta, violão e cavaquinho
}

\author{
Tristeza \\ morte, choro, vela,caixão \\ flores / espinho
}

E o que Noel pensava da beleza? No referente a beleza das mulheres, encontram-se muitas em suas canções e também em biografia. Ele as exalta com galanteios: "as morenas tão formosas a terra um dia vai comer", por elas ele repudia o sol em "Feitiço da Vila": "Sol, pelo amor de Deus, não vem agora que as morenas vão logo embora”. A beleza da vida, concentrada na boêmia, presente na roda de samba, numa simples conversa no botequim com amigos e entre tantas coisas na madrugada que sintetiza todos esses momentos.

Contudo a reflexão sobre a morte se estende a respeito do questionamento e sobre a finalidade da vida; dúvida e certeza se misturam para responder se há outra encarnação fato que lhe traz um grau de contentamento: "Estou contente / consolado por saber /que as morenas tão formosas / a terra um dia vai comer" e aqui o verbo saber não expressa dúvida de que seremos alimento da terra e ainda com realce ao destaque de saber que o que se acha belo (as morenas) será decomposição. Admira a beleza sem esquecer do perecível e da fugacidade da vida. Noel usa o contexto da morte para mostrar a parte daquilo que é transitório, e se apresenta sincero na questão da falsidade, tão presente na sociedade humana, acompanhando o homem julgamento póstumo.

Noel fala ainda de dívidas, e juntamente aos seus problemas de finanças apresenta a questão de não ter herdeiros, mais uma descoberta de mestre, uma vez que se realiza no testamento a partilha dos bens e as questões financeiras ficam esclarecidas: aos herdeiros, parentes, amigos e aos demais. É aí então feita a afirmação da criação de rimas a/b/a/b apresentada a declaração vintém/ ninguém, levando a afirmação de não pagar um vintém a ninguém. 


\subsubsection{Retratos de mulher}

A presença da figura feminina nas letras de Noel aparece muitas vezes atrelada ao tema do amor e, pode-se constatar no conjunto de sua obra várias ocorrências destes pontos no conjunto de sua obra. Ainda que apontado como antiromântico, são relatados em sua biografia vários amores, muitas mulheres e inclusive, casos com mulheres casadas. Esses "casos" são parte integrante do cenário que Noel apreciava muito: a boêmia, a noite, amores sem compromisso e sem comprometimento, mas isso vem mostrar a postura de uma geração, uma influência e expressão de um estilo de vida ligado ao que o samba representava para um grupo.

Para discutir a questão em destaque a escolha das músicas: "Dama do Cabaré”, "Três apitos" e "Último desejo" concentram o foco. São latentes os temas referentes ao amor ao amor e a marcante presença de mulher. Aqui na verdade, uma mulher em especial: Ceci.

\section{Dama do Cabaré}

"Dama do Cabaré” é uma apresentação da noite carioca da época; uma narração constituída de riqueza de detalhes. Há ênfase não só na figura feminina, mas também nos costumes; um "retrato" do cenário é expresso em detalhes registrando o primeiro momento de aproximação na noite relatada, até o dia seguinte à procura da mulher com quem esteve. É a história do primeiro encontro, de amor a primeira vista regado a música, dança e os elementos do cabaré.

A letra conta a história do primeiro encontro de Noel e Ceci. Ele situa lugar, descreve hábitos do ambiente típicos do comportamento social da época, classifica ritmos que dançaram, contudo, Ceci é o centro de todo o cená

rio apresentado, e de seu sentimento de rejeição resultante daquela noite de São João.

Há bebida, cigarro, festa e em destaque, até mesmo no título da canção aparece o ambiente onde se conheceram: foi num cabaré... no bairro da Lapa, já de fato na época centro e reduto dos boêmios. Mas é de fato para Noel uma paixão marcante e conhecedores da música, da pessoa e da biografia de Noel atestam a questão de seu amor por Ceci. É uma demonstração de como fazer samba partindo dos elementos que remontam à crônica, uma narrativa construída para contar a história de um relacionamento, de um encontro e de uma paixão que nasce na boêmia.

O texto remonta elementos de crônica e autobiografia, em estilo memorialista e, em 
certo sentido, saudosista, se levarmos em conta os dois anos que separaram a composição da gravação. Como a letra se refere aos primórdios da relação amorosa Noel-Ceci, não apresenta ainda os conflitos e o amargor decorrentes do ciúme e da desconfiança, característicos de outros sambas a ela dedicados posteriormente. Há destaque para momentos centrais: o encontro (uma breve descrição do tempo que ficaram juntos) uma despedida, (o que faz crer que o breve tempo em que estiveram juntos foi positivo) e termina narrando uma frustração por não haver um retorno positivo do sentimento creditado a Ceci que envia-lhe uma carta enquanto ele a procura.

As imagens construídas nesta composição revelam de primeiro momento uma aproximação, essa é a história do primeiro encontro, Noel avista Ceci e relata sua imagem em meio aos prazeres da noite, da vida boêmia: Lapa, cigarro, champanhe, música esses são os elementos do cenário onde se dá a aproximação: “dançamos um samba” essa afirmação deixa claro que houve relação de proximidade entre ambos, ou seja, se conheceram, conversaram e o próximo cenário mostra que naquela noite, apreciaram um a companhia do outro até o momento em que deixaram o recinto. E o prazer da companhia de Ceci é expresso claramente, uma vez que ele foi procurá-la no dia seguinte. Na "cena" final uma carta é recebida essa leva-o a concluir quem a mulher que ele conhecera e reafirma sua posição como dama do cabaré, ela usa e abusa da diplomacia mas não gosta de ninguém.

\section{Três apitos}

A canção apresenta a relação de uma tecelã, marcando então o processo de industrialização nacional, com um homem enciumado, sismado de sua obediência e prontidão ao apito da fábrica, questionando sua demora a atender seus chamados. Em contrapondo a sirene da fábrica, ele apresenta a buzina de um automóvel, outra marca da modernidade e de progresso. O texto registra elementos com mistura de crônica narrativa, remete a valorização / observação do cotidiano. É também uma revelação do cotidiano como um detentor da arte, revelando poesia e a música.

Katia Abud, professora pesquisadora enriquece essa paráfrase comentando que:

No Brasil, o período posterior a primeira guerra mundial foi marcado pela expansão industrial e, nos anos 1930, as fábricas apareciam como contraponto do mundo rural, como a principal característica do mundo urbano. A posição entre o urbano e o rural no século XX se expressaria por meio de diferentes elementos, dos quais um dos mais significativos se encontra já no próprio título da música: o apito da fábrica que disciplina o 
tempo do trabalho, relacionando-o ao relógio e não ao tempo da natureza. (Abud2005, p.309-317)

Ainda como estudante de Medicina, em 1931, Noel Rosa estava dividido entre dois amores. Clara, a Clarinha, do bairro de Vila Isabel, e vizinha do jovem sambista. Noel e Clara há quatro anos tinham um relacionamento que agradava muito a mãe do jovem sambista, porém, esse relacionamento indefinido, deixava-o confuso, e Clara por sua vez, sabia da existência de Josefina, a mais ciumenta das duas, se irritava com os famosos "sumiços" do compositor pela capital fluminense. Enquanto Clara suportava Noel com uma paciência de Jó, "Fina" ameaçava quebrar o violão de Noel se não se explicasse. Porém, nesta letra a musa inspiradora é "Fina".

A apresentação da mulher nesta letra se mostra singular mediante as outras canções do corpus, o texto tem como personagem uma operária de fábrica de tecidos e pode ser associada ao período de industrialização da era Vargas:

As fábricas de tecidos foram um dos primeiros tipos de indústria a se estabelecerem nas cidades brasileiras. Nessas fábricas, o operariado era predominantemente feminino. Não causa estranheza portanto que ele se dirija a uma moça que "faz pano". (Abud2005, p.309317)

A mulher submissa ao chefe, ao pai, ao marido, a igreja, ao homem e essa qualidade de reforçar submissão aparece em "Três apitos" quando Noel se mostra indignado e imperativo, e apresenta o motivo da sua indignação justificada pela a pela opção - na verdade condição - da sua atenção ao trabalho, chamada pelo apito da chaminé deixando assim Noel a esperar.

Os elementos introduzidos: a indústria e a modernidade evocados no apito da fábrica, ainda que haja uma interessante discussão da probabilidade da fábrica não ter apito:

Há muita confusão em torno deste samba, em especial sobre quem seria sua inspiradora. Mas é certo que foi mesmo Fina. Diria Noel em entrevista ao Diário Carioca 4 de janeiro de 1936: "Três apitos" resume o romance mais sincero de minha vida gloriosamente romântica..." Que outra operária de fábrica se encaixaria nessa declaração? A confusão parece ter crescido quando se sabe que nem a América Fabril nem a Hachiya tinham apito, enquanto a Confiança, perto da casa de Noel, esta sim emitia nada menos de sete silvos diários. Esses detalhes, porém, não mudam nada. Não significam que a musa de Noel trabalhasse na Confiança. Apenas, como está claro na letra, ao ouvir o apito da fábrica, ferindo seus ouvidos, ele se lembrava da amada. Quando 
aos "três apitos" do título, eram os primeiros que a Confiança fazia soar de manha, um às 5 horas e 45 minutos, para despertar os operários que moravam nas redondezas; outro às $7 \mathrm{~h}$, longo, de uns 20 segundos de duração marcando a hora de entrada; e o terceiro às 7horas e 45 minutos, curto, a que chamavam de "pu". Queria dizer que quem chegasse depois dele perdia o dia. (Máximo \& Didier 1990 , p. 185)

Uma junção da questão do apito transcende a discussão da sua efetiva existência ou não, realça temas da modernidade, Tota (2001), aproxima Noel a uma proposta oswaldiana, apresentando o boêmio (sou do sereno) como o contrário do burguês e não o proletário clássico, expropriado da mais valia marxista justificando assim o automóvel, como um ícone da modernidade individualizadora, símbolo da velocidade amorosa dos modernistas/futuristas, usado contra os apitos das chaminés que ferem os ouvidos do homem sensível às transformações anti-lúdicas amorosas.

Uma das grande criações de Noel, inspirada em sua
namorada Josefina, a Fina, que trabalhava numa fábrica
de botões. O compositor pensava, inicialmente, que ela
trabalhasse na fábrica de tecidos, daí a citação de tal
indústria na letra (um detalhe a mais no conflito entre a
arte e a realidade. Afinal, ele também não escrevia
versos "junto ao piano", como diz a letra) Os últimos
versos ("Nos meus olhos você lê / Que eu sofro
cruelmente / Com ciúmes do gerente / Impertinente /
Que dá ordens a você") foram escritos de pois da obra
pronta, quando soube, pela própria Fina, que ela era
cobiçada pelo contramestre da fábrica, Jerônimo
Feliciano da Encarnação. (Chediak 1991 vol. I, p. 127)

Seus biógrafos apresentam ainda outro elemento objeto de ciúmes de Noel um contramestre fazendo transparecer que a fidelidade de Fina ligada ao apito da fábrica maior que seu desejo de atender a buzina de seu carro revelando em todo esse conjunto as figuras da modernidade, assim como o comentário referente ao vestuário feminino em alteração por questões de valorização do corpo, marcam a emancipação da mulher.

“O comentário sobre a ausência de meias, mais do que o frio que possa sentir a personagem, liga-se a mudanças no comportamento feminino. No final da segunda década daquele século, nas grandes cidades brasileiras, especialmente na capital da República, as mulheres abandonavam o uso das grossas meias de algodão que escondiam suas pernas."

(Abud, 2005, 317)

Ao advertir Fina sobre sua decisão em tornar-se guarda noturno, ele a faz compreender seus motivos: o ciúme. Para vigiá-la em seu período de trabalho e aproveita para atestar o fato 
de ela ser a musa da sua canção. Nesse conjunto as palavra-chave é modernidade.

\section{Úlimo desejo}

O fim de um amor, esse é o tema central da canção. Essa é a marca e a palavra-chave do registro de "Ultimo desejo". A voz que fala apresenta-se em terceira pessoa, dando a possibilidade de ser compreendida tanto de um homem para uma mulher ou vice versa.

Esta é a terceira canção que apresentada priorizando o enfoque ao tema do amor na letra de Noel é "Último desejo”. O final de relacionamento que se iniciou numa noite de São João, em 1934, no Cabaré Apolo, conforme se registara na canção “Dama do Cabaré”. Noel fora forçado por sua família a casar-se com Lindaura e seguiram então para uma temporada em Belo Horizonte, na tentativa de curar a tuberculose. Quando regressam a capital fluminense, soube que Ceci havia encontrado um novo amor: Mario Lago. Como se pode conferir pelo título da canção, o pedido derradeiro é expressos por sentir que lhe resta pouco tempo de vida.

A letra desta cançao é apontada como "Canto de Cisne" e obra-prima para Máximo (2010 p. 54). Por meio de metáforas há uma aproximação da alegria na noite de São João, (noite em que se conheceram $^{88}$ ) com a tristeza expressa por motivo do fim de um relacionamento de um sentimento forte: sem foguete, sem retrato, sem bilhete, sem luar, sem violão elementos que remetem à festa e grande alegria, ausentes agora nesta noite em que tudo se apresenta como contraposição da alegria.

Essa música é a narrativa do romance de Noel com Ceci. Um final de relacionamento como o pedido derradeiro de um condenado, como sem dificuldades, se pode conferir pelo título da canção um pedido ser expresso por meio de uma indicação de pouco tempo de vida. Como remonta o que se encontra em Máximo \& Didier (1990), Noel procura Ceci na noite do seu aniversário, eles se encontram, ele porém já está doente e ele propõe que passem à noite juntos.

De madrugada, quase amanhecendo, ela desperta. Abre os seus olhos aos poucos, vê que ele não está a seu lado. Vira a cabeça, assusta-se ao encontrá-lo na mesma posição em que o deixara ao adormecer, sentado numa cadeira aos pés da cama, imóvel, os olhos fixos nos seus. Os primeiros raios de soletram pela janela do quarto de hotel. E Noel ali, imóvel, como uma pedra olhando para ela. Há muito de adeus nesse olhar. Um adeus, porém, quase parece significar mais do que uma simples separação amorosa (Máximo \& Didier, 1990, p. 446).

88 Conforme conta a letra de "Dama do Cabaré" 
As marcas de antíteses acentuam a expressão dos sentimento, estes se apresentam desnudos, fator que acentua e consegue apresentar o amor entre Noel e Ceci: calo / falo tudo / nada. O amadurecimento e o adoecimento por tuberculose trouxeram-lhe dois novos temas, geralmente entrelaçados: amor e morte. Era como se toda paixão fosse marcada por um desfecho trágico e inevitável.

A combinação poderia se tornar algo pesado demais, não fosse Noel o autor. Seu bom humor, afinal, continuou infalível até o último instante, pedindo à amada que fale bem dele fazendo assim prevalecer sua dose de bom humor: às pessoas que eu detesto, diga sempre que eu não presto.

\subsubsection{A expressão de amor pelo Rio de Janeiro e pela Vila Isabel}

O olhar apaixonado de Noel pelo Rio de Janeiro e seus bairros se revelam em várias de suas composições, foram escolhidas para representar esse conjunto as canções: "Eu vou pra Vila", "Feitiço da Vila" e "Palpite infeliz".

\section{Eu vou pra Vila}

A primeira delas, "Eu vou pra Vila”, revela um passeio, um diálogo com outros bairros do Rio de Janeiro funcionando como interlocutor de outros sambas apresentando a cidade: a Pavuna, a Gamboa e não só citando-os nas letras mas valorizando a construção de rimas: $\mathrm{Na}$ Pavuna tem turuna / na Gamboa gente boa e juntamente sua construção depois de citar os encantos dos bairros mencionados, fala da Vila Isabel onde Noel faz a apresentação da Vila como um denominado reduto do samba justificando assim o fato de esse bairro possuir uma “polícia camarada".

A feliz referência ao nome do bairro e aos tempos de outrora onde se localizava a sede da coroa não passam despercebidos e indicam a Vila como um lugar de excelência do samba.

Ou seja, o caráter lúdico e religioso contido no samba tradicional (ainda não moderno), juntamente com sua associação ao universo negro - que por esse tempo era visto como um atentando à civilização -, em Vila Isabel não seria reprimido pela polícia. A repressão ao universo não civilizado (ao samba) não existindo em 
Vila Isabel (ainda segundo a letra da canção de Noel), transformava esse novo reduto de samba em algo atrativo para os demais sambistas, pois continha um elemento diferente (no caso: a não repressão), na elaboração do espaço ideal para o sambista atuar, especialmente num momento de transição da repressão policial para a aceitação social do samba. (Fenerick 2007, p. 23)

Sua autoria se destaca em vários elementos, porém aqui em especial nos componentes que conferem o tom biográfico como: não tenho medo... eu sou... eu vi gente... eu vou... recebi uma medalha... mas também narrativos e por ser a composição que rende seu primeiro tributo ao bairro onde nasceu, como comprovamos no relato de seus Máximo e Didier (1990), Noel apresenta aqui um dos primeiros registros de que se tem notícia de um dos mais marcantes aspectos dessa fase pioneira da história de nossa música popular: a perseguição policial aos batuqueiros, aos compositores e cantores de samba. O compositor conta de si e fala do que gosta: de samba e do domínio que tem sobre tal, da "segurança" que sente na companhia da roda de samba e do seu amado bairro.

Com “Eu vou pra Vila”, Noel Rosa não só rende seu primeiro tributo ao bairro onde nasceu, como também faz um dos primeiros registros de que se tem notícia de um dos mais marcantes aspectos dessa fase pioneira da história de nossa música popular: a perseguição policial aos batuqueiros, aos compositores e cantores de samba. (Máximo \& Didier 1990, p. 138)

É bem verdade que a capital fluminense perdeu um médico, mas para compensar a perda do médico carioca, o Brasil ganhou um dos maiores sambistas de todos os tempos. Se com seus estudos de medicina não Noel não obteve êxito, no samba a situação é bem diferente como assume em sua composição: "na roda de samba eu sou bacharel”.

\section{Feitiço da Vila}

Um hino, uma declaração de amor à Vila Isabel, nisso se sintetiza a canção "Feitiço da Vila”. A voz da canção apresenta-se em terceira pessoa como narrador onipresente e somente nos últimos versos se revela a primeira pessoa. A prosopopeia permite aos galhos, lua e 
arvoredo na Vila (que abraça o samba ) a dançar ao longo de toda a noite enquanto dura o samba de onde o sol é expulso. A letra da canção confere a identificação da Vila no Brasil como a fonte do samba.

"Feitiço da Vila" apresenta o bairro querido de Noel Rosa descrevendo suas atratividades e destacando o samba da vila, mas toda a construção tem sua origem revelada na linha final na exclamação: "eu sou da vila". Essa expressão apresenta-o como aquele que pertence ao subúrbio do Rio e do samba, uma identificação de boêmio.

\begin{abstract}
Noel Rosa, no entanto, lançaria uma ponte entre bairros e segmentos sociais diversos, e transitaria muito à vontade entre os bambas do Estácio. "Poeta da Vila", ele reconhecia como ninguém o "Feitiço da Vila" (Isabel) nos versos com os quais deu voz à sofisticada melodia de Vadico: "Quem nasce lá na Vila/ nem sequer vacila/ ao abraçar o samba/ que faz dançar os galhos do arvoredo/ e faz a lua nascer mais cedo." Não era para menos. A Vila Isabel de fins dos anos 20 e início dos 30 transpirava musicalidade. (Paranhos, $1981-113,2003)$
\end{abstract}

O malandro, com referência no corpus nas letras "Não tem tradução" e "Rapaz folgado" aparece como um personagem distinto na cultura carioca conforme as observações de Sandroni 2001, destacando não só a exaltação a Vila, mas percebe ainda uma menção de enaltecimento à música negra apontando o samba como instrumento para quebrar as barreiras entre o "bamba e o bacharel" comprovado em: Lá na Vila Isabel, quem é bacharel não tem medo de bamba/São Paulo dá café, Minas dá leite, e a Vila Isabel dá samba.

O bacharel - no Brasil, um símbolo da cultura letrada, branca, europeia. O bamba - seu equivalente na cultura mestiça carioca. A Vila aparece como um espaço utópico de confraternização dos dois, espaço que é logo projetado na cultura do país: o samba é apenas um "produto"a mais, mais uma riqueza que se soma ao café e ao leite, principais produtos de Minas e São Paulo. Ele defende seu direito de participar do mercado, de entrar nas prateleiras do mercado nacional...(Sandroni 2001)

Em feitiço da Vila o compositor usa da prosopopeia personificando os elementos da natureza que não resistem se entregar ao ritmo do samba fazendo: "dançar os galhos do arvoredo e a lua nascer mais cedo". Difícil é não ser diferente, a Vila Isabel na década de 20 a 30 transpirava musicalidade, espaço privilegiado de muitas atividade cultural, a Vila, bairro da classe média, deixou para o cenário cultural/ musical brasileiro dando foco ao samba 
fazendo ecoar no rádio os nomes de Almirante , João de Barro, Francisco Alves, Nássara, Orestes Barbosa, J. Cascata, Lamartine Babo e as amizades "estranhas" de Noel recrutadas entre "gente do morro" entre outros frutos frondosos da fase áurea do rádio. Outra particularidade desta composição é a polêmica "briga" de Noel com Wilson Batista na qual se fazia a apologia a malandragem.

\section{Palpite infeliz}

A letra da canção se dirige a uma terceira pessoa, formando assim um diálogo percebido já no título da canção. O foco se concentra na qualidade/ modo de fazer samba na Vila Isabel e no bairro em si.

"Palpite infeliz” apresenta o ápice da discussão, literalmente, terminada em samba entre Wilson Batista e Noel Rosa. Noel destaca a Vila com predileção, mas não descarta gostar muito de outros celeiros do samba, citando-os na letra e quem não aprecia tais redutos do samba, é anunciado como alguém no qual não se pode confiar, aquele que desconsidera coisas importantes, ou seja, uma pessoa que "não sabe o que diz".

\footnotetext{
“Obra-prima da música carioca, o samba ficará gravado para sempre na memória do povo. E muito especialmente na do jovem, talentoso Wilson Batista (já em seu primeiro verso Noel nos chama a atenção para este detalhe: Quem é você ...?). Porém, mais do que um contra-ataque, um fim de duelo, um desfecho de polêmica, "Palpite infeliz" é obra sutilmente integradora, promove a confraternização do mundo do samba, defende Vila Isabel com elegância, sem situá-la a cima do Estácio de Sá, Salgueiro, Mangueira, Oswaldo Cruz, Matriz. Sutileza de Noel Rosa que, ao comentar uma partícula, atinge todo um universo." (Máximo \& Didier 1990, p. 372)
}

Wilson Batista, com a apresentação da canção "Lenço no pescoço", apresenta o desejo de vida dos malandros, gerando então oportunidade para a inspiração de Noel manifestar-se com o samba "Rapaz Folgado", que por sua vez faz uma crítica àquele estilo de vida citado em "Lenço no pescoço". A resposta de Wilson vem em seguida com "O Mocinho da Vila", que incitou Noel gravar uma das composições que dizem ser a obra-prima de Noel: "Feitiço da Vila". Sem dar-se por satisfeito Wilson grava "Conversa Fiada", todos acompanhavam a discussão musicada até que finalmente vem de Noel lançamento de "Palpite Infeliz", que obtém sucesso inesperado. Há uma regravação de Wilson, irritado com o sucesso da canção 
de Noel ele hostiliza o Poeta da vila apontando falhas referente ao físico de Noel, mas ele não retruca a provocação. Há ainda outras provocações não mais revidadas agora fazendo dessa forma um silenciar da polêmica.

"Palpite infeliz" mostra claramente um diálogo: informal e sem agressividade. Porém fica visível e claro o seu carinho, o seu amor e sua preferência pela Vila e a supremacia do lugar como o lugar do melhor samba:

"Quando penso no Boulevard, nas ruas pacatas que guardam os meus melhores segredos, nas esquinas prediletas para as reuniões da turma que aprendeu a fazer samba vendo sambar o arvoredo, o meu coração, incuravelmente tamborim tocado por estrangeiro. E eu vou alongando o pensamento e vou pensando que a cidade inteira é Vila Isabel..." (Máximo \& Didier 1990,p. 38)

\subsubsection{O olhar voltado a sociedade de 30}

Rocha (2002,p. 112) indica que Noel Rosa era aquele que usa o samba para sustentar a "filosofia", sintetizando uma crítica incisiva aos preceitos da sociedade burguesa e uma opção categórica pelo samba como expressão de sua liberdade tal ideologia confere-se nos sambas "Onde está a Honestidade?", "O orvalho vem caindo" e o "Samba da boa vontade" são as canções que escolhidas para a faceta que se volta a um contexto do olhar mais social do compositor em questão.

\section{Onde está a Honestidade?}

A letra desta canção aponta para reflexões do cenário político da época. O povo é a voz que faz a pergunta originando o título de tal composição indagando a figura do político que se beneficia e se promove com o dinheiro da sociedade.

O sucesso da canção na época se dá por meio da identificação do povo com a letra, infelizmente tão atual. Não é difícil imaginar qual é a mensagem da música Onde está a honestidade? Fruto da originalidade de Noel e uma proeza de sua época, uma infelicidade é constatar o mesmo fato tão presente na atualidade de nosso país, a composição corresponde ao ano de 1933, fato que justifica lamentar conferir sinais de atualidade em tal letra. Lamentavelmente pode-se considerá-la atualíssima porque a realidade do país, tantos anos depois, apresenta os memos problemas contemplados diariamente nos jornais, conforme o assunto da canção. 
A enfermidade que preocupava o espírito de Noel era a de seu pai, conforme se vê na carta dirigida à minha prima Célia. Grande homem o pai de Noel! Na Prefeitura do Distrito Federal, propôs medidas de combate à exploração de preços, defendeu o povo do assalto dos gananciosos. Por isso foi caluniado e perseguido até adoecer gravemente, fato que inspirou o samba de Noel intitulado "Onde está a honestidade?" (Pacheco 1958,p.121)

A letra da canção infere a postura dos políticos usando o dinheiro público em busca de autobenefício fazendo o que Noel chama de vassoura dos salões da sociedade. É aquele soma: joias, criados, anéis, dinheiro enquanto o povo vive o que é narrado em "O orvalho vem caindo". Contrapondo as duas canções, "Onde esta a honestidade?" é a apresentação da vida social dos políticos da época e "O orvalho vem caindo" é a voz do povo.

As referências, claras ou não, ao "país de tanga", soma de preocupação com a pobreza e certeza de que pouco se fazia para combatê-la, já estavam em Noel Rosa muito antes de Vagas embarcar no trem revolucionário. E seguiram com ele vida afora. Por exemplo, três anos depois, faria um samba supostamente dirigido a uma grã-fina ("Vassoura dos salões da sociedade, que varre o que encontra pela frente"), mas na verdade endereçado aos corruptos em geral. A mensagem caberia perfeitamente no Brasil de sempre e não apenas no daqueles dias. A começar pelo refrão:

E o povo já pergunta com maldade:

"Onde está a honestidade?

(Máximo \& Didier 2010, p.18)

O contraste social apresentado na voz do povo, admirando-se da condição na qual se encontram, contemplam seus governantes sem ter nenhuma herança nem parente apresentarse ao assumir a liderança de seus cargos com um dinheiro que nasce de repente.

De modo bastante incisivo, Noel mostra a população atenta a condição de individualismo onde o malandro aqui, na forma mais propícia pela qual era compreendido na época, se destaca na figura do político, capaz até mesmo de promover: festivais de caridade em nome de qualquer defunto ausente fazendo constatar a frequência de corrupção entre aqueles que mais podem fazer pela igualdade do país. Ao que percebemos na atualidade o problema não se modificou; só mudaram os protagonistas e segue o cenário: desigualdade, fome, desemprego, baixos salários, a justiça apresenta-se de forma injusta. Máximo \& Didier (1990) explicam a canção, como inspirara na perseguição de Manuel Medeiros Rosa, seu pai. Motivo? Era um homem honesto em suas decisões optando por não prejudicar o povo.

Durante dois anos - de 1930 a 1932 - estes documentos sé tratam de promoções e elogios ao servidor público Medeiros. Por exemplo, no dia 8 de outubro de 1932, o 


\begin{abstract}
diretor interino Annibal Martins Ferreira agradece-lhe "pela colaboração que the prestou durante sua interinidade como diretor-geral, no desempenho das funções de ajudante, cargo que ocupou com manifesta competência". Pois bem. Dois dias depois, 10 de outubro, o capitão Luiz Ceso Uchôa Cavalcanti, recémnomeado nomeado diretor-geral titular da mesma Inspetoria, dispensa Medeiros como ajudante. O que se segue é uma clara divergência entre os dois. Sobre várias questões administrativas, principalmente a que trata do reajuste dos preços dos produtos alimentícios. O capitão é a favor dos aumentos. Medeiros, contra. Relatórios de um não deixam nada satisfeito o outro. $\mathrm{O}$ ex-ajudante demostra não haver necessidade de se onerar ainda mais a população, já sendo tao altos os lucros de produtores e comerciantes. Uchôa, por algum motivo, pensa diferente. E resolve afastar Medeiros, colocá-lo longe de tudo que diga respeito ao tabelamento de preços, são aumentados. Por mais de um ano o funcionário antes merecedor de elogios e promoções fica fora de cena. Máximo \& Didier 1990, p. 241
\end{abstract}

Que compositor foi mais oportuno, mais contundente e mais verdadeiro na denúncia dos pecados da nossa sociedade? No ano em que este samba foi lançado, já começavam a mostrar a cara os primeiros beneficiários da nova situação política, surgida com a vitória dos chamados revolucionários de 1930. Os novos-ricos apareciam aqui e ali e uma nova classe preparava-se para ocupar as colunas sociais. Sem dúvida, era a essa gente que Noel se referia na sua obra.

Outro fator interessante para propor pensar sobre é a questão da letra ser tão adequada, tão atual para a época de hoje - início do século XXI - uma vez que sua composição é de 1933.

\title{
O orvalho vem caindo
}

A canção trata de problemas sociais: os sem-teto, sem lar, se apossam para fazer de cama de um banco na praça e dessa forma, eles tem por despertador o guarda-civil cujo salário estava atrasado. Com essa letra, Noel mostra sua consciência sobre as condições de distância entre o povo das ruas e a ordem oficial da política brasileira conforme a reflexão de Cunha (2010) Noel deixa transparecer em muitas de suas composições a ideia de que mesmo os representantes dessa ordem vigente - policiais, autoridades, funcionários públicos e dessa forma, há representação de parte da imensa quantidade de gente que não compreende a complexidade do sistema, suas corrupções, seus conchavos e, portanto, também são vítimas da exploração econômica e ideológica.

São apresentadas não uma, mas várias questões sociais: os salários baixos, o problema 
da fome, com relação a moradia e sobre as difíceis soluções da atualidade. Oliven apresenta a ideia de que a marginalidade:

\begin{abstract}
"Nesse sentido cabe relembrar quanto o trabalho manual no Brasil tem historicamente sido considerado uma atividade não - dignificadora, algo reservado somente para os escravos...

Como se sabe, o fim da escravidão no Brasil não significou o surgimento de uma sociedade mais aberta, mas a continuidade do padrão de dominação oligárquica. Mesmo com a intensificação da industrialização, o trabalho assalariado não se tornou uma fonte de qualificação, pois a ordem social continua sendo fortemente excludente. Assim, a malandragem, ao recusar o trabalho assalariado, se configura numa alternativa transformada em estratégia de sobrevivência numa sociedade que marginaliza o trabalhador, não the assegurando condições de viver decentemente do fruto de seu labor." (Oliven2010 p. 24)
\end{abstract}

Oliven aponta assim para compreensão de que a malandragem ganha então se cria e se concentra na nossa música popular nesse momento de fase de conflito nas décadas de 1920 a 1940. Esse pensamento é reforçado nessa canção nos versos que mostram uma posição retratando o trabalhador como aquele que trabalha e nada tem enquanto o malandro, não trabalha e enfrenta os mesmos problemas apontados pelo trabalhador: "que o salário ainda não viu” uma vez que o malandro, apresenta-se como se pode contemplar até mesmo em melhor posição do que o trabalhador que se submete ao sistema: a minha terra dá banana e aipim /meu trabalho é achar quem / descasque por mim/vivo triste mesmo assim.

Máximo \& Didier (1990) veem nessa composição um samba perfeito e acreditam ter vindo desse samba sua imagem e apresentação de sambista popular, fato natural se ao considerar o quanto este samba tem grande identificação com o povo mediante ao humor registrado na letra.

De certo modo, o samba é uma retomada de Com que roupa? Sem o caráter formalmente revolucionário daquele, mas outra vez falando de um "Brasil de tanga" 89 , de brasileiros cuja sopa não tem osso nem tem sal, de um solo fértil onde nascem banana, aipim, tudo, e mesmo assim do homem do povo passando bem um dia, mal dois e três. Há até referência aos servidores públicos que ganham pouco e não recebem pontualmente, representados pelo guarda-civil transformado em despertador de pobre, sua atenção se estende a esses fatos por amar os subúrbio, a vida simples e a gente humilde que o habita. No fundo,

89 Expressão usada por Noel sobre a situação do povo brasileiro na difícil época da quebra da bolsa de 1929 
e é tão ou mais urbano que de Vila Isabel.

Neste dias em que fazem cada vez mais frequentes as migrações dos moradores lá de longe para o Centro (ou deste para os bairros litorâneos) movidos quase sempre pela necessidade de mostrarem o quanto melhoram de vida, ou o quanto ascenderam socialmente, Noel prefere a direção oposta. São sedutoras mas enganosas mas enganosas as luzes da cidade. Já o subúrbio é ambienta de completa liberdade. Como o próprio Noel nos garante no lindo samba intitulado Voltaste, cronica carioca da melhor feitura, o malandro de volta ao subúrbio depois de constatar que não há nada de novo lá no centro da cidade. (Máximo \& Didier 1990, p.272 )

A década de 30 apresenta muitas marcas na vida política brasileira, foram muitos fatos marcantes: deposição do presidente Washington Luís, por Getúlio Vargas, com a ressalva de que Getúlio assumiu o governo em (1930) com poderes ditatoriais. Dois anos depois (1932), iniciou-se a Revolução Constitucionalista de São Paulo, dando a vitória a Getúlio Vargas; no ano seguinte (1933), foi criado o Partido Integralista Brasileiro, de uma clara inspiração fascista. No ano de 1935 conheceria a chamada Intentona- Comunista, esta fora esmagada também por Getúlio, e ano da morte de Noel - (1937) o ditador desfechou outro golpe, implantando o Estado Novo.

Nesse período, (todos esses sete anos), a censura à informação e às artes foram exercidas rigorosamente pelo DIP (Departamento de Imprensa e Propaganda), para Noel, uma preocupação que gostava de julgar com sátira e às vezes até sarcasmo.

\section{Samba da boa vontade}

Típico registro do estilo "noelina" envolvendo a sátira na visão de seu olhar atento à sociedade da época, para uma composição de resposta às convocações do Governo Provisório de Getúlio Vargas para que o povo mantivesse o otimismo, mesmo enfrentando sérias dificuldades. E mesmo sendo datada de 1931, é lamentavelmente como a letra comentada anteriormente de extrema adequação com a atualidade. É uma recomendação ao povo que adote o fingimento, é recomendado fingir contentamento e alegria, ainda que em tempos de crise.

Era na época, muito conhecido, um verso que se cantava: "é melhor apertar agora para que a fartura venha depois" conforme diziam os governantes. Como dizem Máximo \& Didier (1990), o grau de perenidade deste samba é notável e o chamam de aula de economia 
nas considerações de Noel sobre o que pensa do capitalismo.

Em suas canções Noel aparece com a postura de um enunciador preocupado com a vida das pessoas e com o quadro da injustiças social no Brasil de sua época, e não se pode dizer que ele não tenha coragem de dizer o que pensa e sua bandeira é a música. Ela é a arma que tem em punho, uma semente plantada que pode protagonizar outras ideias, somar com pessoas que partilham do mesmo pensamento e segue fazendo seu trabalho deixando clara sua posição filosófica, fazendo quem esta a sua volta refletir e examinando a realidade de sua época. Noel cria um meio de expressar-se por meio da música.

A mistura e o preparo de sua criação melódica e simples se concentra no povo para quem compõem e cria, deixando claro existir um sistema onde os ricos podem gastar seu dinheiro à vontade, pois ele sempre acaba voltando às mãos de políticos desonestos que não precisam economizar. "Gastei o teu dinheiro | Mas não tive compaixão | Porque tenho a certeza $\mid$ Que ele volta a tua mão”.O anúncio, na primeira frase , revela e funciona como um pedido. Getúlio Vargas, conservando seu sorriso exige de seu povo não apenas sacrifícios, mas acima de tudo boa vontade.

O sorriso de Getúlio Vargas podia não fazer o povo se animar, como diria a marcha carnavalesca que saudaria sua volta ao Catete dali a 20 anos, mas era um dos muitos meios de o novo presidente conquistar a simpatia do carioca. E não apenas ele. Todos, em seu governo ainda provisório, deveriam se deixar contagiar pelo caráter populista que os novos tempos exigiam no contado com o brasileiro, o carioca em particular. Sorrir era a palavra de ordem. (...)

Pelo menos por duas razões talvez não fosse hora de o presidente sorrir. A primeira, sua chegada ao Catete ter sido precedida por um mês de violência - tiros e bombas, mortes e baixas graves, prisões e deportações. A segunda, ele assumir em meio à crise agravada pela quebra, um ano antes, da Bolsa de Nova York. (Máximo\& Didier 2010, p 12)

Foi com a "quebra" da Bolsa de Valores americana em 1929 o momento em que o Brasil teve a primeira grande crise de superprodução do café, esse fato obrigou o governo brasileiro promover a queima de estoques para tentar segurar os preços, posterior a essa fase, o Brasil superou a crise e voltou a ser o maior produtor mundial de café, a apresentação para os versos "comparo meu Brasil a uma criança perdulária / que anda sem vintém / mas tem a mãe que é milionária" se justificam assim no conjunto da letra irônica, mostrando atualidade em tempos de escândalos do meio político social e econômico do país.

Tecnicamente, a crise que já ocorreria por aqui tinha a mesma causa da de lá: a desvalorização, no mercado internacional, dos produtos de exportação. No caso brasileiro, do café. A produção 
excessiva, imprevidente e descontrolada, dos cafezais de São Paulo, somada à má qualidade que o grão brasileiro adquirira (pedra, feijão, terra e até graveto eram adicionados ao café de modo a tornar mais pesadas a sacas mandadas para o exterior), reduziu de dois terços para menos de um décimo o café brasileiro consumido pelo europeu. (...)A situação agravou-se durante todo 1930 e, se ajudara Vargas na vitória sobre a política do café com leite, não deixava de ser uma dor de cabeça. (Máximo \& Didier 2010, p. 12)

Compreender estes fatos são fundamentais para decifrar o que se "esconde" no verso "que iremos a Europa num aterro de cafép" contrapondo-se a pobreza de grande parte da população "mesmo que a vida esteja feia / e que vivas na pirimba / passando a pirão de areia.

Um estranho país que espera alcançar o grau de desenvolvimento dos europeus atirando seu café ao mar. Em "Samba da boa vontade", há referência de riqueza foca o país e não um sujeito e daí vem a possível interpretação de construir um aterro de café possível de ser construído entre a Europa e o Brasil” (Jubran, 2000 p.24 ) o país revela na herança da colônia uma riqueza monocultural.

\subsubsection{O Filósofo do samba}

São muitas as letras de perfil satírico de Noel, porém "Feitio de oração" aponta para contraposições apresentadas neste samba que concentram: achar e perder, a dor e a alegria, a melodia e a nostalgia, o morro e a cidade e tantos outros paradoxos, nos aproxima a visão da vida que se levava na periferia, onde o samba se fazia, se criava no seu berço dando alegria a quem vivia na tristeza, afinal a letra diz claramente: sambar é chorar de alegria. As referencias de Máximo \& Didier (1990) revelam dados de venturoso encontro de Vadico e Noel citado por seus biógrafos como um encontro abençoado, mas Sandroni 2001 encontra muitos elementos para dialogar com a música "Feitio de oração".

Sandroni (2001) apresenta reflexões sobre o morro e a cidade. Noel faz uma reflexão sobre de onde vem o samba destacando no registrado desse antagonismo um retrato do perfil carioca, do perfil da configuração da capital fluminense sendo o morro parte da geografia da cidade um lugar de destaque de referencia tanto de paisagem, e já nos anos de 1930 o morro é a favela, a periferia.

“....morro e Estácio versus Copacabana, está expressa em

90 A crise do café, com a queima ou lançamento ao mar de milhões de sacas com as quais a superprodução abarrotara os armazéns de São Paulo. (Máximo 2010, 12) 
outro samba, dos mais famosos de Noel, cujo título evoca mais um paradoxo, pois ali se trata de um samba em "Feitio de oração"

(Sandroni 2001, p. 174 e 175)

\section{Feitio de oração}

Em primeira pessoa: alegria, tristeza, saudade somam a mistura que sintetiza uma forma de oração. O samba é apresentado como o elemento principal que está em toda parte, ou ainda, superando a discussão da propriedade do samba como elemento do morro ou da cidade, é apresentada como fruto daquele que "suporta uma paixão" experimentando seus resultados, será concedido a esse conhecer o elemento essencial para se compor um samba.

A música "Feitio de oração" celebra justamente esse encontro, diferente de todos os outros que o poeta da Vila mantinha com o sambistas de morro. Vadico, com seu sambacanção, criou condições para a poesia de Noel afirmar que " o samba na realidade, não vem do morro no lá da cidade / e quem suportar uma paixão / sentirá que o samba, então, / nasce no coração...” Estava justificada a parceria.

\footnotetext{
O "morro" e a "cidade" : esta oposição reaparece, em incontáveis outros sambas, antes e depois de "Feitio de oração" desde já citado "A favela vai abaixo" de (Sinhô, 1927) até "O morro não tem vez" ( Jobim e Vinícius, 1963) Ela aparece também na famosa manchete com a qual o jornal $O$ mundo Sportivo anunciava em 1932 a realização do primeiro concurso oficial de escolas de samba - "A alma sonora dos morros descerá para a cidade".

Se o samba "não vem do morro nem da cidade" é porque existe um lugar que não é nem uma coisa nem outra, ou é as duas ao mesmo tempo ; um lugar onde finalmente essa oposição tão obvia - infelizmente - para os cariocas 1933 como para os de hoje, deixa de fazer sentido. Este lugar é por um lado a Vila, não a Vila real, mas a utópica que Noel inventa na letra de seus sambas... ..o samba, então, nasce no coração

(Sandroni 2001, p. 174 e 175)
}

Desse encontro com Vadico e a partir dele, suas composições ficaram ainda mais melancólicas e pessimistas. É o que acontece com "Feitio de oração", a primeira canção que fizeram juntos, música de Vadico e letra de Noel: Quem acha vive se perdendo/ Por isso agora eu vou me defendendo/ Da dor tão cruel desta saudade/ Que por infelicidade/ O meu peito invade. A cada dia Noel consumia mais álcool. Essa letra mostra para um discurso para a identidade do Brasil, um revelando um diálogo de abrangência sócio-cultural. A marca do humor aqui aparece e espraia entre a ironia fina juntamente com o lirismo doce no que se 
refere a crítica social, o conjunto aponta para uma representação do Brasil na imagem de país orgulhoso por de suas grandezas, mas com uma alegria que não se manifesta completa compondo "esta triste melodia".

"Feitio" como um todo: quer me parecer que o "Feitio" mas triste das discussões (nacionalidade) sobre a origem do samba (feitas por estrelas), inventando o Brasil na tristeza, na saudade e na melancolia da paixão suplicante, uma tristeza, uma saudade e uma melancolia, no entanto, elegantemente contidas, sorridentes, cortesãs ("cariocas").

O que a análise do "Feitio" parece indicar - estando eu convencido de que se está aqui, face a essa canção, à frente de um discurso absolutamente fundante sobre o que seja o Brasil - o país tem consistência, merecendo, contudo, considerações que a retirem da ambiguidade com que pode eventualmente ser lida. O "Feitio" claramente recusa a discussão sobre a origem do samba, metáfora do Brasil. Ele não somente a recusa, mas a vê com escárnio, desenhando-a como uma discussão feita pelas elites, por ele construídas como ignaras. As elites aqui - recordo - são como o cantor que não sabe "pegar o tom". Desejo referir que Noel Rosa parecia estar muito bem informado sobre toda a polêmica acerca das origens do Brasil - e particularmente da música brasileira - que se passa no cenário intelectual do país a partir da célebre Semana de Arte Moderna, de 1922 ( Bastos, 1994)

\section{Silêncio de um minuto}

A ausência, e o distanciamento e posterior a esse quadro, a razão dessa distância: o luto. $\mathrm{O}$ amor pela escolha daquele que quis partir, fora silenciado, acabado. Em seu lugar fica a dor, de tão grande, capaz de silenciar o samba. Em "Feitio de oração", tristeza aparece como elemento necessário pra se fazer um samba, aqui o silêncio deixado pela pessoa que se foi é maior, é silêncio absoluto. O discurso direto, mostra o que se vai como causador consciente da dor de quem fica: tu cavaste a minha dor.

Uma letra apresentada por seus mais completos biógrafos como um samba que beira a perfeição. Partindo de um tema universal, recorrente em todas as culturas, Noel cria partindo da imagem do amor acabado, da dor do amor que se acabou. O sentimento de perda, revela a lacuna deixada pela mulher amada que se vai, assemelha-se a morte na co-relação de ambos que deixam a vida de alguém sem repor "nada" no lugar: um amor acabado parecendo-lhe tão irremediável quanto a morte. 
Dessa associação amor X morte, vem a imagem criada com a associação ao luto e aqui um registro convencional social do uso da cor preta como luto, já no caso irremediável da perda do amor, toda e qualquer cor não tem significado especial demonstrando assim a dor da perda do amor quase ou mais dolorosa que a perda ocasionada pela morte.

A força de um epitáfio conforme citam Máximo \& Didier (1990) se podem constatar ao observar a letra, um pesar de dor e lamento, mas confrontando o momento vivido por Noel como apresenta sua mais completa biografia, encontramos um florescer de amor em sua vida afetiva: casamento com Lindaura, uma oportunidade para reatar seu romance com Ceci e a marca do epitáfio vem da lapide de seu pai que cuja a morte foi de suicídio.

No episódio, Noel procura o médico para saber se o suicídio é um mal hereditário: Pois eu não vou deixar que isso me aconteça! - diz com firmeza como se para convencer. - Eu quero viver. Não deixarei que aconteça comigo o que aconteceu com meu pai!. Noel aqui experimenta a tristeza, vê uma pessoa amada em silêncio absoluto, e essência de sua vida se abala levando-o a afirmar "meu samba esta de luto" e o motivo da tristeza vem do interlocutor da canção ${ }^{91}$.

A composição contém harmonia na rima simples e na mistura com elementos de uma composição que possui uma linguagem informal em discurso direto com um interlocutor.

\section{Filosofia}

Na canção "Filosofia", pode-se perceber a imagem de um enunciador representandose condenado, estigmatizado pela sociedade ou ainda por parte dela. Ele se apresenta protestando uma dor existencial, ou ainda um filósofo existencial na condição daquele que está descontente com a sociedade e com a realidade do seu insucesso econômico.

A origem desse fato pode-se encontrar nas considerações de Vasconcelos (2004), o autor mostra como sua convivência na Vila Isabel, apresentando-o como frequentador de vários grupos e classes sociais, sem escolhas demonstrar preferências, a informação presente no capítulo 42 de Máximo \& Didier (1990) nas seguintes palavras: “Ceci nunca viu Mário sentar-se com um daqueles mendigos que tantas vezes aliviaram o estômago com pratos de sopa pagos por Noel ("Vem cá, come com a gente ..." em vez de mandá-lo embora, a consciência tranquilizada por dois ou três tostões depositados no fundo de um velho

$91 \quad$ Máximo \& Didier 1990, p. 367 
chapéu)."

Rocha (2001,p.112) no seu "Adoniran Barbosa : o poeta da cidade : trajetória e obra do radioator e cancionista, os anos 50" explica que tomando como uma espécie de manifesto, esta letra de Noel Rosa, coloca o samba como sustentação de sua "filosofia", que sintetiza uma crítica incisiva aos preceitos da sociedade burguesa e uma opção categórica pelo samba como expressão de sua liberdade frente a tal ideologia. É certo que , novamente aqui, observase um sentido de oposição ente dois mundos.

De um lado, o mundo que é desdenhado pelo compositor, ou seja, a sociedade "hipócrita" pautada pelo código burguês, de outro lado, o mundo do próprio cancionista que resiste em seus propósitos ao ironizar a sociedade que o ignora. Outra vez, o samba é evocado como um elemento de contraposição entre dois universos.

Noel se sente reprimido por uma classe social, que dita quais são os valores que devem ser apreciados. Diante das dificuldades que abatiam o país, o cidadão deveria passar uma imagem de progresso em sua vida pessoal, seu emprego, seu dinheiro, sua ânsia de erguer a pátria. É sem expressar grande contentamento ante a realidade que vive, com a situação de sua condição social, faz colocações expondo suas dificuldades que enfrente em contexto social. $\mathrm{O}$ sua composição expressa descaso, não quer se incomodar com a imagem apresentada pela sociedade: "não me incomodo que você me diga que a sociedade é minha inimiga".

Mayra Pinto (2010) discute a a posição apresentada dos "personagens" apresentados nas letras das canções: "Conversa de Botequim" e "Filosofia". A pessoa que figura em narração nas letras, mostra-se como aponta Mayra uma "máscara satírica". As duas canções refletem posicionamentos cobrados pela sociedade, para manter a aparência, ainda que esta seja ilusória.

Por intermédio da análise de duas canções, "Filosofia" e "Conversa de botequim", propõe-se que, pela abordagem frequente do tema do fingimento, Noel fala ora criticamente, ora num tom debochado da necessidade de uma máscara social como uma estratégia para sobreviver em sociedade. Nesse sentido, propõe-se outra filiação para a obra noelina: a ironia romântica que confrontava os valores do mundo burguês como uma estratégia discursiva recorrente. (Mayra Pinto p. 17,2010)

Outra questão para a qual se deve atentar é que a figura do malandro, tem sua representatividade não só de modo negativo, mas também se incorpora a essa imagem o fracasso, o descaso com o trabalho, não se pode esquecer que os olhares da sociedade se voltam sempre para as apreciações do capitalismo, a década de 30 não era diferente.

Aqui se manifesta claramente a questão: a malandragem $x$ valores. A malandragem 
nega o que a sociedade e os valores sociais prezam a valorização do trabalho, do dinheiro, dos "bons costumes", em contrapartida às ideologias de malandragem e boêmia, numa palavra a oposição aos bons costumes. A malandragem é exatamente a forma de romper com os paradigmas da sociedade.

Noel, com a experiência que teve de ver seu pai trabalhar tanto, apreciar demasiadamente a honestidade, e em decorrência disso, vi-o ser levado pelo à depressão e à morte. Revela nesta letra não ter nenhum apreço para ser notado, desejando uma posição que lhe dê um destaque social. Aqui ele expressa estar indiferente ao desprezo e que sua posição de boêmio, malandro e vagabundo o conduziu.

A filosofia traz o auxílio desejado para viver livre. Livre de quê? Do sistema criado pela sociedade, livre de ter que se adequar aos moldes sociais. Mas há um traço de personalidade que é preciso para seguir contra os ditames sociais, é nisso que a filosofia lhe ajuda e lhe faz legitimar sua existência.

Aqueles que não se adaptam a essa realidade da sociedade, a sua forma de ação e pensamento, estão em desacordo com a harmonia social, sendo, portanto, marginalizados, deixados de lado. Veja-se os versos de Noel que mostram isso: "deixando de saber se eu vou morrer de sede ou se eu vou morrer de fome". Ou seja, o representante da elite, rico, entregue à ilusão do sucesso através do status, vivia tão impregnado dos valores que lhe eram impostos sem contestá-los, que não lhe sobrava tempo para compreender o que é a felicidade, coisa que, aliás, não poderia comprar: "Quanto a você da aristocracia/ Que tem dinheiro mas não compra alegria". Noel mostra consciência dessa cituação. 


\subsubsection{O espaço da sátira na obra de Noel Rosa}

Há diversos os compositores que tratavam da presença do humor na música brasileira entre eles se encontram: Bastos Tigre parceiro de Lamartine Babo no final dos anos 20 e início dos anos 30 , período no qual o humor do país foi em grande escala influenciado pelas questões que apareciam no emergente cinema falado americano, Vadico e Noel Rosa, e outros, tomaram como alvo de paródias situações apresentadas.

\section{Não tem tradução}

A letra da canção infere uma grande valorização do nacional ante o estrangeiro e o estrangeirismo. É comentando situações, linguagem, comportamentos e danças, que se estabelece a supremacia do nacional ante o estrangeiro. A linguagem do morro, do malandro, nossa gírias, são consagradas no verso: "é brasileiro , já passou de português". O samba, o supra-sumo do produto nacional, não tem tradução.

Segundo as considerações de seus atenciosos biógrafos, Noel Rosa tinha avessia a estrangeiros e estrangeirismos. Fidedignos a vida do compositor, fizeram observações sobre sua infância consultando registros de sua má impressão deixada por prestamistas ${ }^{92}$. Essa má impressão é fator resultante do que seus biógrafos descrevem como pavor do moradores da Vila Isabel, cena que Noel viveu em sua casa, assistindo a vizinhos fingirem não estar em casa e se esconder para não serem cobrados:

O pai tantas vezes endividado, apelando para os emprestadores de dinheiro. Quando a importadora faliu... Dramas, tragédias, farsas. Em tudo isso o prestamista há de ser sempre o vilão de sua história. A menos romântica e a mais constante musa de seus versos. (Máximo \& Didier 1990, p.42)

Máximo \& Didier (1990) não apresentam Noel como um xenófobo e sim como um nacionalista intransigente, afirmam sobre não combinar com o jeito de ser de Noel, de fato, a identificação de suas letras visa aproximação com o povo, o morro, os seus citados bairros cariocas onde não se encontra valorização e apreço por estrangeirismos e nem mesmo conhecimento destes. Seus biógrafos o apresentam como quem da valor ao nacional, ou como ele mesmo chamou seu apreço é sempre maior com as “coisas nossas”"em lugar do fox-trot e

92 Emprestadores de dinheiro: poloneses, húngaros, belgas, romenos. E até portugueses. Vêm de todos os pontos da Europa. Há também os sírios, árabes, libaneses. Os europeus, tenham a origem que tiverem, são conhecidos genericamente por "judeus". Os outros venham de Beirute, Cairo ou Marrocos, são simplesmente "turcos". Judeus, turcos, portugueses, não importa quem sejam. Noel aprende muito cedo a ver no prestamista o fantasma que transforma em pesadelo os sonhos dos moradores do bairro. Cf. Máximo \& Didier 1990, p.42 
o mesmo fazem suas letras retratando um grupo de personagens incluindo: a mulata, o malandro, a mulher que trabalha na fabrica de tecidos, a do cabaré, os bairros do Estácio, Matriz, Pavuna, Vila Isabel apresentando satisfação em estar na periferia, como já foi mencionado, sem fazer acepção de pessoas.

De 1920 a 1931, Máximo \& Didier (1990), registram a marcha intitulada Good-bye de Carmem Miranda, a chegada do cinema falado ao Rio de Janeiro e o nosso primeiro talking film fonte motivadora do samba Coisas Nossas, acompanhando todos esses fatos, registram mudar a moda feminina nos trajes e penteados e a masculina registrada nos bigodes e costeletas, esses fatos revelam ainda a pressão da indústria cultural com seus valores alastrando-se na sociedade da atual capital do Brasil, de todos os lados se fazia sentir a forte influencia estrangeira:

O teatro, como a boêmia, sofria influência parisiense, só que com escala em Lisboa. Confeitarias e café, também com jeito europeu, recebiam os homens e as mulheres de melhor condição social para, em volta de uma mesa, conversarem sobre trivialidades ou coisas sérias: poetas, romancistas, doutores, funcionários públicos, políticos, industriais, banqueiros, o Rio mais chique frequentava os cafés. Era difícil encontrar, no que esses personagens diziam uns aos outros, sinais da arte do bem-conversar na qual o carioca - com espírito, malicia, inventiva, humor - se tornaria único. Se algum sinal já havia, era no botequim de esquina, barato, aberto a todos geralmente escondido sob o nome de "café", como se o de "botequim" lhe negasse classe e respeitabilidade. (Máximo \& Didier 2010, p. 9)

Patindo de tais considerações, ao longo deste estudo percebe-se na obra de Noel Rosa, a presença de valorização do nacional em detrimento de influencias apresentadas para a época, recorrendo a expressão "fazer uma falseta", que pode ser interpretada como uma traquinagem, um charme do sambista para encantar "Risoleta", viabilizando a possível interpretação da identificação feminina, dada a nação brasileira, que se deixa seduzir pelo falseta do malandro e logo "esquece do francês e do inglês". Outro fruto da influência do cinema era a presença do inglês incorporando-se no teatro, linguagem dos jornalistas chegando aos sambistas: até o malandro aderiu ao hellos e bybies" incorporação nos cumprimentos.

Sem ser dado a compartilhar de qualquer ufanismo tolo supondo-se, é claro, a possibilidade de existir ufanismo que não seja tolo - Noel Rosa era um dos que compactuavam, no entanto, com as restrições feitas ao modismo do fox-trot. $\mathrm{Na}$ verdade, com frequência ele torcia o nariz diante do que lhe parecesse americanizado, da mesma maneira como achava deplorável ver brasileiros cantando em outras línguas. Nas palavras dos seus melhores biógrafos, "os 
estrangeirismos simplesmente não combinam com seu jeito de ser. São chiquês de grã-finos e intelectuais enfatuados, pura moda, mania de exibição". Sob a ótica de Noel, o Brasil está aqui perto, na cidade do interior, no morro, no bairro, na esquina. Ou mesmo no botequim, na gafieira, na pensão de mulheres, no carnaval, na roda de jogo, nos lugares, enfim, onde todos os brasileiros se igualam. (Mesquita, 2003, $\mathrm{p} 45)$

Os relatos de sua mais completa biografia apontam sua alegria ao ouvir Ismael Silva dizer "me faz carinhos" contrapondo "faz-me carinhos", forma correspondente a Portugal, há destaque à linguagem do malandro, a linguagem e a do morro verdadeiro "pólo de identidade nacional e faz valer os produtos culturais do povo, tais como o samba, a figura do malandro e o morro . Ele afirma a independência cultural do Brasil, diante da hegemonia do cinema americano." 93 nas gírias usadas na letra, seu jeito de pronunciar como "coisas nossas" declarando originalidade completamente nacional.

Desde o título, primeira mente pensado como "Sem tradução" apresenta-se uma identidade única, uma consciência de nacionalidade justificada dentro de um cenário político, como ele mesmo enfatiza em sambas como "Samba da boa vontade" um nacionalismo instigado a população, mas em Noel, não é fruto de uma pressão de fora e sim gosto pelo nacional.

Há pesquisas que buscam aproximação entre essa visão de Noel ao desejo de Mário de Andrade:

\footnotetext{
Como se sabe, Mário de Andrade nutria o desejo de captar a fala que nasce do Brasil popular, do "Brasil brasileiro", como que a saborear o coco que o coqueiro dá. Nessa perspectiva, a sintaxe é submetida a um processo de abrasileiramento em busca de uma língua brasileira. E essa sintaxe,musicalmente falando, para Noel era o samba. (Mesquita, 2003, p45)
}

\section{Seu Jacinto}

"Seu Jacinto" é um dos tipos noelinos. Integra sua galeria de personagens: vagabundos, malandros, pedintes, pães-duros, marginalizados da sociedade. Seus personagem apresentam um tempo, um espaço de representatividade justificando e destacando a linguagem coloquial, as gírias e os modismos vocabulares, revelando o quadro de uma época, e ao mesmo tempo se mostrando atento a mudança ao que surge de novidade no mundo da cultura.

Uma brincadeira para o carnaval de 1933, revela segundo seus mais dedicados

\footnotetext{
93 Sociedade Brasileira de Estudos de cinema - Socine Vol. II e III p. 111
} 
biógrafos um brasileiro que vive de aparências, esconde a fome "afrouxando o sinto" expressão recorrente na atualidade para expressar economia, apuros, contenção de despesas, revelando na condição do seu Jacinto o perfil de muitos brasileiros nas condições apresentadas nessa letra.

\footnotetext{
Vai provocar $\mathrm{m}$ protesto pela impressa assinado por Jota Tojeiro, pianista e compositor que em carta aberta refere-se à campanha liderada por Renato Murce pela moralização e restauração do bom gosto nas letras da música popular brasileira. (Máximo \& Didier, 1990 p. 231)
}

$\mathrm{Na}$ verdade, como em outras reflexões se pode perceber o olhar fixo de Noel Rosa sobre a sociedade, pode se encontrar já no primeiro verso, ele claramente se diz adverso à situação de seu Jacinto, mediante as dificuldades de fome e necessidade experiência de muitos brasileiros da época de sua composição (presente na atualidade). E mesmo enfrentando dificuldades "ele gosta de comprar a vista" fato que expressa ausência de problemas financeiros, e por que ele é chique? Essa questão de fato aparece como um questionamento e uma afirmação, ele tem consiência de sua realidade, é pobre, mas opta pela ilusão, somente a morte pode lhe render um comentário de real contato com o que é de fato chique.

A vida de aparências e o ato de ludibriar frequentadores de um recinto,como se pode conferir há alguns elementos: a malandragem e a aparência; esses dois elementos compõem um cenário de mentiras o que gerou pesados comentários como:

\footnotetext{
"o final da letra desta marcha é bem desagradável para quem tem família e tem a infelicidade de ter um rádio em casa ligado para qualquer das nossas estações" (Diário Carioca, 5 de janeiro de 1933, apud Máximo \& Didier 1990 p. 239)
}

\section{Gago apaixonado}

Em primeira pessoa, o discurso de um homem apaixonado se dirige a uma mulher e lhe confessa um sentimento desmedidamente intenso, dizendo que suas mentiras estão por abalar seu sistema nervoso. Em lugar de deseja que ela fique com ele, encontrando nela grande falsidade, ele roga-lhe uma praga.

A construção apresentada usa como base o amor reflete a criação para a composição de um quadro onde aparecem amor e sentimento de desprezo contrapostos, tornando o homem gago e agressivo, diante da falsidade, e mais como ele mesmo coloca, diante da crueldade da figura feminina a quem ele sempre manifestou carinho, agora ele roga uma praga e não mais pede sua volta. Esse conjunto faz resgatar a lembrança dos elementos de em 
"Pela décima vez", em ambas as canções aparecem um motivo justificado pela força da natureza se sobrepondo ante a fraqueza humana, é o coração rendendo-se ao sofrendo por escolha própria, por predestinação. Monteiro (2000 p. 38), identifica o espaço que seria concedido ao romantismo dando lugar ao efeito do amor e da saudade, tornando o homem, por motivo expressamente afetivo: gago e agressivo, e deixando claro o motivo de jogar a praga na mulher: a falsidade. Esse é o motivo da súplica de "volte" ter se tornado praga.

Mesmo neste samba singular a mentira não deixa de estar presente, num processo de repetição constante. (Monteiro 2000 p. 38)

O humor em Noel aparece como uma qualidade, e o destaque a criatividade nessa letra por ele interpretada é incontestavelmente original, se tornou uma canção obrigatória no repertório de Noel onde quer que ele estivesse apontado como imortal sucesso:

Em entrevista que concedeu a um jornal carioca, Noel Rosa assim respondeu ao repórter que queria saber a sua música preferida: "É "Gago apaixonado", porque além de ser original, os meus vizinhos e os seus papagaios não conseguem cantá-lo." É, sem dúvida, um dos melhores exemplos do humor e da criatividade de Noel. A gravação, feita pelo próprio autor, é histórica, pois apresentava, além de Napoleão Tavares no pistom com surdina e Luiz Americano no clarinete, o extraordinário cantor Luiz Barbosa não cantando, mas fazendo o ritmo com lápis batendo em seus dentes. (Chediack 1991, p. 16)

A mulher aparece como a personagem que finge - a ela pertence o dom de iludir, de dissimular, causando o então chamado: estrago. Mas Noel Rosa sempre transformou desgraças em melodia. Deixou histórias impagáveis, em muitas composições, por diversos motivos, a mulher aparece como uma constante em diversas letras de muitos cancionista, ora sujeito da traição, ora como a que sofreu a desilusão, a traição, mas uma coisa é certa, ela é sempre a culpada pela dor do sujeito, a responsável pela dor de um sambista que sofre e chora. A novidade aqui é a dor transformada em piada na brincadeira com o gago. 


\subsubsection{A crônica em função da música brasileira}

Foi Noel quem demonstrou - com suas letras inspiradas no linguajar do povo, nos episódios do dia-a-dia, nos personagens de sua cidade, nos temas de sua época, como os maus governos, a falta de dinheiro, a fome, o crime, a marginalidade, a boêmia - que tudo cabe numa canção séria, ainda que haja lugar para o humor e a crítica irreverente.

Os elementos da modernidade: a eletricidade, gramofones e rádios são, o bonde, apitos de fábricas, chaminés madrugadoras, não são desprezados por pelo olhar de Noel atendo ao cotidiano. Essa época, uma possível interpretação dos anos de 1930, momento em que o país vive em busca de raízes, se abraça e procura algo de frutuoso no campo das artes da literatura, ou do pensamento, a música floresce: “já se multiplicava pelo advento do rádio. E para ocupar as ondas sonoras era preciso acasalar letras e agrupar notas musicais novas todos os dias. "94 Para representar o olhar cronista de Noel Rosa as canções são: Século do progresso, "Conversa de botequim" e "Rapaz folgado".

\section{Século do progresso}

A letra da canção conta sobre a brutalidade da violência e de suas novas formas no século do progresso. Um valente morto por um revólver. A canção fala de um homem bruto, assassino aparecendo ali então vítima de algo que ele tanto fez, morto por um tiro. Os acontecimentos são registrados perto da roda de samba, onde há harmonia e clima de amizade, sentimentos contrários a motivação do clima, são interrompidos pelo infortúnio.

Apresentado por seus biógrafos como "soberba crônica da vida carioca, do mundo dos malandros, do sinal dos tempos" e comentada por Vasconcellos (2004) como apresentação desta canção revelando-a uma música-símbolo, a canção apresenta um retrato no qual aparece a entrada do revólver a violência urbana como se observa, acentuando a violência a seu limite: a morte.

Sandroni 2001, observa os elementos que ele considera formadores para a concentração do samba-folclórico: noite, ar livre, luz da lua como aponta, os versos feitos na roda de samba justificando a ocasião do encontro, amizade e proximidade favorecendo o clima de alegria entre os presentes, inferindo, sobre os não presentes não serem próximos.

94 Leonel Kaz e Nigge Loddi na organização de textos da obra de Máximo 2010 O morro e o asfalto no Rio de Noel Rosa, p. 7 
Os eufemismos empregados nos versos professor dos desacatos / que ensinava aos pacatos / o rumo do cemitério inferem o caráter do homem morto, conforme a voz descritiva crônica da canção que na última estrofe, traz um sujeito identificado como "alguém" e fica a pergunta, pelos versos que esse "alguém” canta na roda de samba, não seria então o assassino trazido a um lugar livre das suspeitas?

Um ponto triste de reflexão sobre a questão da chegada do novo século é a marca da violência acentuada. Violência essa motivadora da criação desse samba, mais um episódio registrado por seus atentos biógrafos, explorado mais detalhadamente por Elias 2005, em seus comentários sobre parcerias no mundo do samba. É por motivo de um desentendimento entre Zé Pretinho e Noel, o surgimento desse samba como resposta pelo envolvimento de Zé Pretinho com Kid Pepe ${ }^{95}$.

Rocha (2004) afirma que em briga de malandros, a navalha, instrumento empunhado com valentia para enfrentar o outro, se usava numa luta corpo-a-corpo, cara-a-cara, a navalha não exatamente funciona como arma letal, mas para deixar marcas. O revólver revela a atitude tão covarde quanto a interpelação de Zé Pretinho a Noel Rosa; Pretinho, surpreendendo Noel de costas com um tapa e atirando-o assim ao chão,atitude tão covarde quanto ao uso do revólver.

\section{Rapazfolgado}

Um conjunto de recomendações sobre comportamento, porte de objetos e comentários sobre itens de uso pessoal formam a letra desta canção de advertência a valorização do sambista.

Essa letra é a volta da reflexão sobre a divergência de Noel Rosa com Wilson Batista mediante a figura do malandro apontado em Sandroni (2001), identidade do sambista. Aberto a contato com todos, Noel não era uma pessoa que discriminava alguém por sua condição social, ao contrário, como reforçam Máximo \& Didier (1990) e em inúmeras de suas citações mostram sua amizade, parceria e visita aos morros da capital fluminense daí vem sua triste surpresa com a letra de Lenço no pescoço.

95 (...) nascido de uma "vingança" que Noel faria a um, como se dizia na época , "valente". Kid Pepe, expugilista, se passava por compositor e parceiro de várias músicas, inclusive de Noel, mas na verdade, seu nome era imposto nas parcerias. Noel só conseguiu se livrar dele porque contou com a ajuda de um outro valente, o Zé Pretinho. Mesmo assim, isso não impediu que Kid Pepe desse uma bofetada em Noel. Com a brilhante fase: "no século do progresso, o revolver teve ingresso para acabar com a valentia", Noel se defendia, ao mesmo tempo em que preconizava o fim da guerra das navalhas entre os malandros. 
Se em sua utopia, a circulação entre o Estácio e Copacabana, deve ser de mão dupla e aquela entre o morro e a cidade, livre e desempedida; se o bacharel se o bacharel não teria medo do bamba (que como vimos é o outro nome do malandro), e a identidade deste último não devia ser afirmada como provocação mas como um feitiço sutil - não é de se espantar que não tenha gostado do samba de Wilson Batista. Neste o malandro prefere a etiqueta de "vadio" a de compositor profissional, e não porta apenas chapéu, tamanco e lenço, mas também uma navalha pronta a se dirigir contra o primeiro bacharel que cruzar seu caminho. (Sandroni 2001)

A parceria de Noel com seus amigos do morro, transformaram o que era refrão em sucessos do rádio chegando na indústria através dos discos, essa amizade, esse caminho, de acordo com Sandroni 2001 e os biógrafos de Noel, são exatamente o que ele traduz no verso: "já te dei papel e lápis" e para contrapor a violência de quem leva uma navalha: arranja um amor e um violão" é uma postura de repúdio a agressividade deixando clara dessa forma suas impressões sobre a figura apresentada em Lenço no pescoço: "joga fora esta navalha que só atrapalha". Porém, fica explícito não haver ressentimento da parte de Noel e no mais, há sobretudo um desejo de preservar a boa imagem do sambista e boa referência para o samba, perseguido pela polícia, como fica claro em: "da polícia quero que escapes”. A apresentação da contraposição dos elementos: tamanco $x$ sandália, o lenço branco $x$ gravata, são todos elementos reunidos para apontar o ápice da letra centrado nas diferenças entre o malandro e o sambista: malandro é derrotista que só tira o valor do sambista.

\section{Conversa de botequim}

O informal ambiente de bar, na verdade um café, apresenta como personagem protagonista um cliente já conhecido do estabelecimento, por essa razão, pedindo somente uma média e um pão com manteiga e trata o garçon como se esse fosse seu empregado exclusivo sobrecarregando-o de diversas solicitações e posterior a tudo, avisa que não tem dinheiro para pagar a conta.

João Máximo, ressalta sobre a vida de Noel, uma frase que sintetiza sua vida e sua obra: "Noel teve uma importância que pode ser resumida em duas palavras: transformação e integração. "96 A explicação para tal, se aplica em no fato de se poder afirma a transformação por ser Noel uma pessoa que demonstrou com sua obra, com suas letras, com sua criatividade e inspiração na fala popular, como ele mesmo afirma, partindo do cotidiano, dos episódios do dia a dia, nos personagens de sua cidade, nos temas de sua época, como os governos, a falta de dinheiro, a fome, a mendicância, a boêmia:

$$
\text { (...) que tudo cabe numa canção "séria" ainda que haja lugar também }
$$

\footnotetext{
96 Máximo 2010, p. 7
} 
para o humor e a crítica irreverente. E integração porque, num tempo em que parcerias intersociais praticamente inexistiam, o jovem culto de Vila Isabel, com formação universitária, se uniria a nada menos que 13 sambistas de morro (entre os quais Cartola, Bide e Antenor Galharda) para enriquecer a música deles e , principalmente a sua própria. (Máximo \& Didier 2010, p. 7)

Considerado um de seus sambas imortais, conforme as referências de sua biografia mais completa, uma prodigiosa crônica dos cafés, "ambiente que o autor conhecia como ninguém (...) a crônica tem como personagem principal um freguês desabusado que, ao preço de uma simples média com pão e manteiga, acha-se no direito de agir como se estivesse em sua casa...”, com fina ironia e observação na apresentação dos personagens, um exemplo bastante interessante é o do malandro da época que "conseguia" quase tudo através de conversa fiada, retrata em versos as principais características populares do Rio de Janeiro do início do século passado:

"Conversa de botequim”, uma prodigiosa crônica dos cafés cariocas e seus folgados frequentadores. Um irretocável retrato da cidade e de alguns de seus tipos, o garçon que passa o pano na mesa como se a dizer ao freguês que este já lhe roubou tempo demais, o sujeito que gasta seu último níquel apostando no jogo do bicho, o interesse um tanto vago pelo futebol (como o de Noel). Quem se lembrar bem dos tempos do Carvalho, em a Isabel, e do papel comunitário que o botequim então - como ainda hoje - se poderá concluir que tudo aquilo, o espírito de se tirar do botequim tudo que ele tem par dar (o cigarro filado, o cartão , a revista, o cinzeiro, o tinteiro, o dinheiro emprestado, o telefone, o recado, a despesa pendurada ficou guardado no coração do poeta.

Mas não é apenas por isso que "Conversa de botequim" pode se incluir entre as mais notáveis peças de toda a história da música popular brasileira. Em nenhuma outra é tão harmonioso o casamento da melodia e letra, pontuação perfeita, acentuação irrepreensível (nem todos têm muito cuidado para com esse detalhe técnico de uma letra, a acentuação da palavra tendo de coincidir com a acentuação musical, isto é , a sílaba mais forte correspondendo à nota sobre a qual recai o acento melódico, do que "Conversa de botequim" é o exemplo definitivo) Um samba que se acaba se convertendo num desafio aos estudiosos. Sendo feito de parceria com Vadico, a questão se põe em dois pontos: ou Vadico fez toda a melodia e Noel criou para ela os mais exatos versos de toda a canção brasileira, ou p próprio Noel teve alguma participação na construção da música - escorregadia como a de um choro. O que é mais provável. ( $C f$. Máximo \& Didier 1990, p. 398)

Cabe ainda a observação das expressões da época na linguagem informal e nas gírias apresentadas acentuados pelo ambiente de descontração apresentado no estabelecimento do botequim. A informalidade desse lugar e a identificação da sociedade carioca pelo espaço fortaleceram o poder de sociabilidade e de musicalidade. 
Na definição de Máximo \& Didier (1990), o botequim aparece como uma verdadeira fonte de entidade integradora. É uma bonita e sincera definição do que realmente o botequim representa. Destacam também seu caráter altamente democrático, uma vez que sua função é cumprida mediante a sua abertura receptiva a todo o público do bairro, os autores afirmam qeu é "a instituição que mais serviços comunitários presta aos homens do bairro. Mais que a igreja, o clube, a delegacia." Há que se concordar, pois não há realmente nenhum exagero nas constatações alegadas pelos autores: "De modo algum. Vendendo refeições fiado, em prestando dinheiro, fixando em suas paredes anúncios manuscritos pedindo ou oferecendo empregos, pondo seu telefone à disposição dos que não o têm..." 97

$\mathrm{O}$ botequim tem sua variação apresentada entre os distinguidos por seus frequentadores e os chamados "pés-sujos" o que Menezes (2004) apresenta em suas considerações o estado natural do botequim: sem sofisticação , mas com fiéis clientes e em suas afirmações, constata a mistura de lar e bar, não com a intenção de jogo de palavras, mas pela intensidade de convívio sem restrições de limite e sensação de prazer da presença, uma vez que não se escolhe um lugar que não se gosta para frequentar, levando a observação dos ambientes como "a fonte do discurso e aquilo que ele engendra" (Maingueneau apud Menezes 2007). 


\subsection{A composição de Noel Rosa}

A parceria, a originalidade, a observação do cotidiano, a adequação da linguagem do povo a suas letras, e ainda outros pontos, Noel Rosa soube trabalhar em suas letras. O lugar onde convive lhe inspira seus personagens, a sociedade da época, os problemas políticos, seus casos de amor, a cidade do Rio de Janeiro e seus bairros, a boêmia do lugar, tudo lhe acrescenta.

Conceber nova linha melódica, escrever sobre um tema qualquer, terminar uma canção compondo sua segunda parte ou a letrando, é tarefa para a qual está afiado o garoto de Vila Isabel. Assuntos diversos causam-lhe interesse e inspiração em seus versos, alguns só serão mesmo compreendidos depois, muitos anos depois de sua morte.

Noel conhece o início do que hoje é denominado indústria cultural: os primeiros anos do processo de registro fonográfico, o advento da gravação elétrica com o uso do microfone e do rádio. Participa das primeiras experiências dos programas radiofônicos com música ao vivo, realizados em estúdios com a presença de público. Nesta época a "máquina da cultura" em formação ainda respeita o criador, a criação e admite a diversidade. Hoje talvez não conseguisse mostrar seu trabalho.

As oportunidades são incentivos inspiradores que Noel aproveita para desenvolver brincando, sem imaginar a importância e significação de suas construções. Compor é falar do que vê, do que o mundo lhe oferece, do que vivem seus amigos, de seus sentimentos. De encantos e desencantos. Tem o olhar atento. E com a facilidade de se expressar melodicamente, de criar versos e rimas com originalidade, garante destaque em seu meio. E, para si, o encantado olhar feminino.

Rapaz de paixão fácil, sonhador, vai fazer do samba, apaixonadamente, motivo para registrar as experiências amorosas que lhe aparecem. A estas vai dedicar boa parte do que realizou na música. Mulheres terão lugar controverso em sua obra e seus amores serão tema obrigatório. Cidadão do mundo, traz o coração aberto ao amor idealizado, o qual nunca conseguirá viver em plenitude. Vai persegui-lo sem descanso, até seu final. 


\section{CONSIDERAÇÕES FINAIS}

A riqueza temática de Noel, a grandeza de sua obra harmoniosa pode suscitar muitos trabalhos. Sua sensibilidade é um destaque do homem de visão da vida urbana, moderna e humana. Inteligente e hábil para a sátira, Noel perpassa do humor ao afeto, do amor a paixão de modo que alcança todas as matizes da vida humana.

Estudar Noel Rosa por subsídio de tais categorias temáticas, além de contribuir melhor conhecê-lo, proporciona descoberta de quanto sua obra está ligada à sua vida e como Noel foi importante para o prenúncio da era de comunicação e faz compreender o quão valorosa foi sua contribuição para o surgimento da indústria cultural, fortalecida posterior a sua morte. $\mathrm{O}$ conjunto de canções exploradas no corpus desta pesquisa apresenta muitas informações sobre a época: linguagem, influência de línguas estrangeiras, a sociedade de 1930 por meio das letras que revelam seu pensamento sobre o governo, comportamento, mulheres e valores.

As letras apresentam uma fecunda fonte de criatividade retirada do meio em que o compositor se faz presente, por isso os temas registram sua vida, como se pode comprovar em letras que conversam entre si apontando uma relação forte com o ambiente social e artístico, com destaque em letras como: "Palpite infeliz" e "Rapaz folgado" - diálogo com Wilson Batista na briga que deu samba. "Não tem tradução" e "Três apitos" - são sambas que falam das transformações culturais da época e as inovações. A interação entre realidade e situação política da época é descrito em "Onde está a honestidade?". Um ponto de discussão encontrase apontado por Mayra Pinto (2010p.18), sobre a irônica máscara social e o fingimento necessário para se manter entre os burgueses mencionados nas letras de "Filosofia" e "Conversa de botequim".

O conjunto de canções exploradas no corpus da pesquisa contribui com o desenvolvimento de novas pesquisas, e até mesmo de práticas pedagógicas ligadas à linguagem, em razão de disponibilizar informações sobre o contexto social de uma época como a linguagem, influência de línguas estrangeiras, as tensões da sociedade de 1930. As composições revelam o pensamento de Rosa sobre política, comportamento social e a mulher.

Partindo de temas universais, o compositor parte da exploração do cotidiano e, com isso , alcança seu sucesso por obter identificação com o povo que se encontra representado em 
suas letras, uma vez que a visão social do povo,não é muito lógico mas pode naquele momento, está na voz de Noel. E não só este fato lhe consagra a popularidade, suas reflexões sobre o amor e a mulher, o humor acima de tudo, registro de uma marca brasileira presente em sua época. O manancial inesgotável de Noel é sua vida, seu bairro, sua cidade, seu mundo, de modo que lhe são assim assegurados sempre temas novos, interessantes, com senso de humor e pelo mesmo motivo se encontra também até o nonsense, como se observou no "Seu Jacinto."

A análise temática da pesquisa, enriquece estudos sobre não sobre Noel e sim do que ele tratou: da cidade, do amor, da mulher, do cotidiano e do samba. Os núcleos temáticos de valorizam o seu talento, contam sobre os costumes da época e da política de um período.

Em núcleos temáticos, Noel revela sua contribuição para a música brasileira em uma obra para se cantar, tocar e fazer pensar, rir, questionar, refletir o contexto da sociedade local e do país.

Sua contribuição para a música brasileira é uma obra para se cantar, tocar e fazer pensar, questionar, refletir o contexto da sociedade local e do país. Grande para o país, para a cultura, para o samba e para a música e rico de elementos para se explorar no meio acadêmico, Noel, chegando a uma marca de quase 300 músicas, se destacou rapidamente como autor. Tornou-se mesmo um poeta universal,pois muitas de suas composições, como se observa podem ser consideradas atemporais. Suas letras, muito originais, o fizeram, de modo visível um moderno e sempre atual.

No que se refere a sua visão de país, de política e da sociedade ele estava muito à frente de seu tempo. A sua importância é devida à originalidade do seu jeito de fazer samba. Ele era uma espécie de cronista da época, que falava de vários temas humanos, como da prostituição, da malandragem, do governo que roubava o trabalhador. Enfim, são temas do cotidiano. Noel é aquele que tem autoridade nos assuntos de que tratou em sua composição, sobre autoria e música brasileira, Noel Rosa pôde dizer: na roda de samba eu sou bacharel. 


\section{BIBLIOGRAFIA}

ALBIN, Ricardo Cravo. O livro de ouro da MPB - A História de nossa música popular de sua origem até hoje. Rio de Janeiro: Ediouro, 2003

, Ricardo Cravo. MPB - A História de um século. / Ricardo Cravo Albin. - Rio de Janeiro: Funarte; São Paulo: Atração Produções Ilimitadas, 1997

ALMIRANTE. No tempo de Noel Rosa. Rio de Janeiro: Francisco Alves, 1977

ANTÔNIO, João. Noel Rosa / seleção de textos, notas, estudos biográficos, histórico e exercícios. Abril Educação: São Paulo, 1982.

AVRITZER, Leandro. Outros autores: Leandro Bignotto, Juarez Guimarães e Heloisa Maria Murgel Staling. Corrupção: ensaios e criticas. Editora UFMG, Belo Horizonte: Minas Gerais, 2008

BETHEL, Leslie. História da américa latina - periodo colonial. 2a Edição Edusp: SãoPaulo,1999

BRUHNS, Heloísa Turuni. Futebol e capoeira: Entre as gingas do corpo brasileiro. Papinus: Campinas - SP, 2000

CABRAL, Sérgio. No tempo de Ary Barroso. Rio de Janeiro: Lumiar Editora, 1993 . As escolas de samba do Rio de Janeiro. Sérgio Cabral. Fontana, 1974

2010 . A B C do Sérgio Cabral: um desfile dos craques da MPB. Editora Esteio, Alves: Rio de Janeiro, 1990

No tempo de Almirante: uma história do rádio e da MPB. Ed. Francisco

CALDAS, Waldenir. Luz neon: canção e a cultura na cidade. Livros Studio Nobel Ltda: São Paulo 1995

CALDEIRA, Jorge. Noel Rosa: de costas para o mar. São Paulo: Brasiliense, 1984 . A construção do samba. Mameluco: São Paulo, 2007

CALDEIRA NETO, Jorge dos Santos. Voz macia: o samba como padrão de música popular brasileira 1917 a 1939. Universidade de São Paulo

CARNEIRO, Edison. Samba de Umbigada. Ministério da Educação e Cultura, Campanha de Defesa do Folclore Brasileiro: Rio de Janeiro, 1961 
CASTELAR, De Carvalho \& Antonio Martins de Araújo. Noel Rosa: língua e estilo. Thex Editora: Rio de Janeiro, 1999.

CHEDIAK, Almir. Songbook - Noel Rosa idealizado, produzido e editado por Almir Chediak Vol 1. Lumiar 2a edição: Rio de Janeiro, 2010 . Songbook - Noel Rosa idealizado, produzido e editado por Almir Chediak Vol 2. Lumiar 1 edição: Rio de Janeiro, 1991 . Songbook - Noel Rosa idealizado, produzido e editado por Almir Chediak Vol 3. Lumiar $1^{\text {a }}$ ediçao: Rio de Janeiro, 1991

DOMINGUES, Henrique Foréis. No tempo de Noel Rosa. Livraria Francisco Alves: Rio de Janeiro: 1977

DUARTE, Paulo Sérgio \& NAVES, Santuza Cambraia. Do samba - canção à tropicália. Relume Dumará: Rio de Janeiro, 2003

ELIAS, Cosme. O samba de Irajá e de outros subúrbios: um estudo da obra de Nei Lopes / Cosme Elias. Pallas: Rio de Janeiro,2005

FENERICK, José Adriano. Nem do morro, nem da cidade: a transformações do samba e a indústria cultural - 1920 - 1945. Tese de doutorado. Faculdade de Filosofia, Letras e Ciências Humanas da Universidade de São Paulo, 2002

FREDERICO, Maria Elvira Bonavita. História da comunicação. Vozes : Petrópolis - Rio de Janeiro 1982

FERREIRA, Felipe. O livro de ouro do carnaval brasileiro. Ediouro: Rio de Janeiro, 2004

FROTA, Wander Nunes. Auxílio lucuoso: samba símbolo nacional, geração Noel Rosa e indústria cultural. Annablume: São Paulo, 2003

GUGA, Domenico. O jovem Noel Rosa. Coleção Jovens sem fronteira, Editora Nova Alexandria: São Paulo, 2003

JUBRAN, O.A.J. Noel pela primeira vez. Brasília, Funarte - Ministério da Cultura, 2000.

HAUSSEN, Doris Fagundes. Universidade de São Paulo, Tese ECA Rádio e política: tempos de vargas e peron. São Paulo, 1992

2003

Rádio brasileiro: epsódios e personagens.EDIPUCRS: Porto Alegre,

LEITÃO, Ricardo. Noel Rosa - poeta da vila, cronista do Brasil. Expressão popular: São 
Paulo, 2009

MÁXIMO, João; DIDIER, C. Noel Rosa: uma biografia. Editora UnB/Linha Gráfica Editora, DF - Brasília, 1990

MÁXIMO, Jõao; Leonel Kaz . O morro e o asfalto: no Rio de Noel. Ed. Aprazível, Rio de Janeiro 2010

MARYZ, Vasco. A canção brasileira. Rio de Janeiro: Francisco Alves, 2002

MOURA, Roberto Murcia \& Sant'Anna, Afonso Romano de. MPB: caminhos da arte brasileira mais reconhecida no mundo, 1998

MONTEIRO, Marcos Antonio de Azevedo. Noel Rosa: a modernidade, a crônica e a indústria cultural. Dissertação de Mestrado em Semiologia. Universidade Federal do Rio de janeiro - UFRJ, Faculdade de Letras Rio de Janeiro, 2000

MUNIZ Jr., José. Do batuque à escola de samba: subsidios para a história do samba. Ed. Símbolo: São Paulo, 1976

NAPOLITANO, Marcos. História e música - História cultural da música popular. Belo Horizonte: Autêntica, 2002

NAVES, Santusa de Castro. O violão azul. Rio de Janeiro: Editora FGV, 1998

NETO, Alfredo Naffah. Outr'em-mim. Editora Plexus - São Paulo 1998

OLIVEIRA, Eduardo de. Quem é quem na negritude brasileira. Congresso Nacional AfroBrasileiro : São Paulo, 1998

PINTO, Mayara. Noel Rosa: o humor na canção. Tese de doutorado em Linguagem e Educação Universidade de São Paulo - USP. Faculdade de Educação, 2000

PEREIRA, Carlos Alberto Messeder. Cacique de Ramos: uma história que deu samba. E-papers: Rio de Janeiro, 2003

PINTO, Mayara. Noel Rosao humor na canção. Tese de doutorado. Faculdade de Filosofia, Letras e Ciências Humanas da Universidade de São Paulo, São Paulo 2010

ROCHA, Francisco. Adoniran Barbosa o poeta da cidade. Editora Atêlie: São Paulo, 2002

ROCHA, SALAZAR, Marcelo. Samba for all. Irmãos Vitale, São Paulo, 1996

SANDRONI, Carlos. Feitiço decente. Transformações do samba no Rio de Janeiro (19171933). Rio de Janeiro: Jorge Zahar/ Editora UFRJ, 2001

SEVERIANO, Jairo; MELLO, Zuza Homem de. A canção no tempo. Vol. 1 e 2. São Paulo:Editora 34, 1997

Uma história da música popular brasileira: das origens à modernidade. 
Editora 34: São Paulo, 2008

SAROLDI, Luis Carlos \& Sonia Vírginia Moreira. Rádio Nacional: o Brasil em sintonia. $3^{\text {a }}$ d. Jorge Zahar Editora: Rio de Janeiro, 2005

SPINA, Segismundo. Normas gerais de um trabalho de grau: breviário para o estudante de pós-graduação. Fernando Pessoa: São Paulo, 1974

SODRÉ, Muniz. Samba o dono do corpo. Ed. Mauad: Rio de Janeiro,1998

SOUZA, Carlos Roberto de. A fascinante aventura do cinema brasileiro. Fundação Cinemateca Brasileira: São Paulo , 1981

SROUR, Robert Henry. Classes, regimes e ideologias. Ed. Ática: São Paulo, 1987

TEACHOUT, Terry. Pops - a vida de Louis Armstrong. Ed. Larousse do Brasil: São Paulo,2010

TINHORÃO, José Ramos. Música popular - Do gramofone ao rádio e TV. São Paulo:Ática, 1981. . Música popular: um tema em debate. Editora 34, São Paulo, 1997

2005

História social da música popular brasileira. Editora 34: São Paulo, . Ramos. O Samba Agora Vai..., Rio de Janeiro: J.C.M. Editores, 1969

VASCONCELLOS, Eduardo de A. Noel Rosa para ler e ouvir. Ed. Barcarola: São Paulo, 2004

VIANNA, Luis Fernando. Geografia carioca do samba. Casa da Palavra, Rio de Janeiro, 2004

VIANNA, Hermano. O mistério do samba. J. Zahar Editor / Editora UFRJ: Rio de Janeiro, 1995

VIANNA, Letícia C. R. Bezerra da Silva produto do morro: tragetória e obra de um sambista que não é santo, Ed. Jorge Zahar: Rio de Janeiro, 1999

ZALUAR, Alba \& ALVITO, Marcos. Um século de favela. $4^{\mathrm{a} E d}$. Editora FGV: Rio de Janeiro, 1998

WISNIK, José Miguel. O som e o sentido: uma outra história das músicas. Companhia das letras. São Paulo, 1989 


\section{REFERÊNCIAS}

ANDRADE, Mario de. Dicionário musical brasileiro. Editora Itatiaia, Belo Horizonte,1999

ALBIN, Ricardo Cravo. Dicionário Houaiss ilustrado: música popular brasileira. Instituto Antônio Houaiss de Lexicografia; Instituto Cultural Cravo Albin. Paracatu: Rio de Janeiro, 2006

BORBA, Francisco S. Dicionário UNESP do português contemporâneo.UNESP, São Paulo, 2004

CARDOSO, Sylvio Tullio. Dicionário biográfico da música popular. Edição do autor: Rio de Janeiro, 1965

ENCICLOPÉDIA. Nosso Século. Editora Abril: São Paulo, 1980, 5 vol. Volume 2

FERREIRA, Aurélio Buarque de Holanda 1910-: Novo dicionário Aurélio da língua portuguesaAurélio Buarque de Holanda Ferreira ; coordenação e edição, Marina Baird Ferreira,Margarida dos Anjos. Positivo: Curitiba, 2004.

MARCONDES, Marcos Antônio (ed.). Enciclopédia da Música Popular Brasileira:erudita, folclórica e popular. $2^{\text {a }}$ ed. São Paulo: Art Editora/Publifolha, 1999.

MELlO, Zuza Homem de. Enciclopédia da música brasileira: samba e choro / seleção de verbetes. Art Editora ; PubliFolha:São Paulo, 2000.

MELLO, Zuza Homem de. Enciclopédia de música brasileira: popular / Seleção dos verbetes. Art Editora; Publifolha: São Paulo, 2000 


\section{ARTIGOS E DOCUMENTOS}

CAVALCANTI, M. L. V. de Castro; LINS E BARROS, Myriam; ARAÚJO, Silvana; MELLO E SOUZA, Marina \& VILHENA, Luis Rodolfo. (1992), "Os estudos de folclore no Brasil", in CNFCP - Centro Nacional de Folclore e Cultura Popular, Folclore e cutlura popular: as várias faces de um debate (série "Encontros e Estudos"), Rio de Janeiro, Funarte/CNFCP, pp. 101-112.

CONFORTE, André. A Cidmar Teodoro Pais. Congresso Nacional de Línguística e Filosofia, cad. XI p. 146, Rio de Janeiro, 2007

CUNHA, R. O SAMBA DE FRAQUE E O MERCADO DE CONSUMO. REVISTA CIÊNCIA E CULTURA PRINT ISSN 0009-6725 CienC. CUlt. VOl.62 NO.4, OCT. 201, SÃo PAUlo , 2010

MENEZES, Leila Medeiros de. Os bares da vida: espaços de sociabilidade e de construção poética. XI Congresso Nancional de Linguística e Filologia, Círculo Fluminense de Estudos Filológicos e Línguísticos; Rio de Janeiro, 27 a 31 de agosto de 2007

REVISTA DA MÚSICA POPULAR nº11, nov. - dez. De 1955

TATIT, Luiz. No tempo de Noel Rosa. [Resenha da Obra: Almirante. No tempo de Noel Rosa. Linográfica: São Paulo, 1977. 218 p.] São Paulo, 2005.

TONI, Flávia Camargo. Revista do Instituto de Estudos Brasileiros. Noel Rosa: 1910 - 1937. Descrição p.131-2. São Paulo, 1987

\section{Sites Consultados}

DATA DE GRAVAÇÃO E DADOS DAS CANÇÕES. Disponível em: http://www.memoriamusical.com.br

Acesso em: 20 mar. 2011.

DICIONÁRIO CRAVO ALBIM DA MÚSICA POPULAR BRASILEIRA. Disponível em: http://www.dicionariompb.com.br

Acesso em: 10 fev. 2011.

DONGA. Disponível em:

http://www.dicionariompb.com.br/donga/biografia

Acesso em: 20 mai. 2011.

NOEL ROSA . Disponível em: http://www.dicionariompb.com.br/noel-rosa.

Acesso em: 15 fev. 2011.

SAMBA. Disponível em:

http://www.dicionariompb.com.br/samba/dados-artisticos

Acesso em: 10 mar. 2011. 


\title{
ANEXO 1 - CARTA PARA A PRIMA CÉLIA
}

\author{
Carta para Prima Célia
}

Rio, $1^{\circ}$ de novembro de 1934

Querida prima Celia.

Só hoje posso responder o que você perguntou, porque meu pai está internado em uma Casa de Saúde na Gávea. Fui hoje visitá-lo. Ele continua com as mesmas ideias: não quer comer, prefere morrer a continuar vivendo longe de nós. O médico porém, garnte que ele precisa de ficar mais três mezes em tratamento, para se curar completamente. Eu não acredito (pra que mentir?) que elle fique bom. Além disso a Casa de Saúde precisa dos $800 \$ 000$ mensais que o cliente paga; não interessando portanto ao médico que o doente saia de lá. Isto é a realidade.

Entretanto, não posso falar assim com minha mãe. A única alegria que ela tem está resumida na inteligência e na aplicação do nosso Hélio.

Ele tem tirado sempre o primeiro lugar, com distinção. É o aluno "modelo" da Faculdade. Desde pequenino já matava galinhas com cabo de vassouras e depois de abri-las com o facão, separava os diferentes órgãos e etc... Ele será um grande veterinário. Está no Exército como enfermeiro de cavalos. Fala muito inglês, pouco francês, algumas vezes lê espanhol, é professor de esperanto e ... qualquer dia esquecera o português. Está completamente "AMERICANIZADO" e ... quase noivo. Minha mãe envia muitas lembranças a todos d'ahi. Ja amolei bastante. Até breve! Um abraço do NOEL. 


\section{ANEXO 2 - MAIS UM SAMBA POPULAR - NOEL ROSA}

\section{MAIS UM SAMBA POPULAR}

Fiz um poema pra te dar

Cheio de rimas que acabei de musicar

Se por capricho

Não quiseres aceitar,

Tenho que jogar no lixo

Mais um samba popular.

Eu bem sei que tu condenas

O estilo popular

Sendo as notas sete apenas

Mais eu não posso inventar.

Se acaso não gostares

Eu me mato de paixão

Apesar de teus pesares

Meu samba merece aprovação.

Por motivos bem diversos

Escrevi meu samba assim

Fiz o coro após os versos

E a introdução eu fiz no fim. 


\section{ANEXO 3 - COISAS NOSSAS - NOEL ROSA}

\section{COISAS NOSSAS}

Queria ser pandeiro

Pra sentir o dia inteiro

A tua mão na minha pele a batucar

Saudade do violão e da palhoça,

Coisa nossa, coisa nossa.

O samba, a prontidão e outras

[bossas,

São nossas coisas, são coisas

[nossas!

Malandro que não bebe,

Que não come, que não abandona o samba

Pois o samba mata a fome,

Morena bem bonita lá da roça,

Coisa nossa, coisa nossa.

Baleiro, jornaleiro

Motorneiro, condutor e passageiro,

Prestamista e o vigarista

E o bonde que parece uma carroça,

Coisa nossa, muito nossa!

Menina que namora

$\mathrm{Na}$ esquina e no portão

Rapaz casado com dez filhos, sem tostão,

Se o pai descobre o truque dá uma coça.

Coisa nossa, muito nossa!

FONTE IMPRESSA: MÁXIMO \& DIDIER , 1990 p.179 
ANEXO 4 - LENÇO NO PESCOÇO - WILSON BATISTA

\section{LENÇO NO PESCOÇO}

Meu chapéu do lado

Tamanco arrastando

Lenço no pescoço

Navalha no bolso

Eu passo gingando

Provoco e desafio

Eu tenho orgulho

Em ser tão vadio

Sei que eles falam

Deste meu proceder

Eu vejo quem trabalha

Andar no miserê

Eu sou vadio

Porque tive inclinação

Eu me lembro, era criança

Tirava samba-canção

Comigo não

Eu quero ver quem tem razão

E eles tocam

E você canta

E eu não dou

Fonte impressa: Vianna, 1999 


\section{ANEXO 5 - MOCINHO DA VILA DA COMPOSIÇÃO DE WILSON BATISTA}

\section{MOCINHO DA VIA}

Você que é mocinho da vila,

Fala muito em violão

Barracão e outros fricotes mais

Se não quiser perder o nome

Cuide bem do microfone

Deixe quem é malandro em paz

Injusto é seu comentário

Fala de malandro quem é otário

Mas malandro não se faz

$\mathrm{Eu}$, de lenço no pescoço

Desacato, também tenho meu cartaz

(modéstia à parte, eu sou rapaz)

FONTE IMPRESSA: CADERNOS DO CNLF, P.146 VOL. XI, N ${ }^{\circ} 15$ INTERTEXTUALIDADE E METALINGUAGEM?, ANDRÉ CONFORTE (UERJ), 2009 


\section{ANEXO 6 - CONVERSA FIADA COMPOSIÇÃO DE WILSON BATISTA}

É conversa fiada dizerem que o samba na Vila tem feitiço

Eu fui ver para crer e não vi nada disso

A Vila é tranquila porém eu vos digo: cuidado!

Antes de irem dormir dão duas voltas no cadeado

Eu fui à Vila ver o arvoredo se mexer e conhecer o berço dos folgados

A lua essa noite demorou tanto

Assassinaram o samba

Veio daí o meu pranto

FONTE IMPRESSA: CADERNOS DO CNLF, P.146 VOL. XI, $\mathrm{N}^{\circ} 15$ INTERTEXTUALIDADE É METALINGUAGEM? ANDRÉ CONFORTE (UERJ), 2009 


\section{ANEXO 5 - FRANKSTEIN DA VILA - COMPOSIÇÃO DE WILSON BATISTA \\ FRANKSTEIN DA VILA}

Boa impressão nunca se tem

Quando se encontra um certo alguém

Que até parece um Frankstein

Mas como diz o rifão: por uma cara feia perde-se um bom coração

Entre os feios é o primeiro da fila

Todos reconhecem lá na Vila

Essa indireta é contigo

Depois não vai dizer que eu não sei o que digo

Sou teu amigo

FONTE IMPRESSA: CADERNOS DO CNLF, P.146 VOL. XI, $\mathrm{N}^{\circ} 15$ INTERTEXTUALIDADE É METALINGUAGEM? ANDRÉ CONFORTE (UERJ), 2009 